\title{
AMBIGUIDADE E RESISTÊNCIA \\ direito, política e ideologia na neoliberalização constitucional
}

TESE DE DOUTORADO

ORIENTADOR: PROF. DR. EDUARDO CARLOS BIANCA BITTAR

DEPARTAMENTO DE FILOSOFIA E TEORIA GERAL DO DIREITO

FACULDADE DE DIREITO DA UNIVERSIDADE DE SÃO PAULO

SÃO PAULO - 2011 


\title{
TARSO MENEZES DE MELO
}

\section{AMBIGUIDADE E RESISTÊNCIA \\ direito, política e ideologia na neoliberalização constitucional}

\begin{abstract}
Tese apresentada como requisito parcial para obtenção do título de Doutor no programa de pósgraduação do Departamento de Filosofia e Teoria Geral do Direito da Faculdade de Direito da Universidade de São Paulo, sob orientação do Prof. Associado Dr. Eduardo Carlos Bianca Bittar.
\end{abstract}


BANCA EXAMINADORA 
Para Marli, Henrique e Laura - tudo e mais um pouco. Ou muito.

Para meu pai, minha mãe e meus irmãos - até aqui! 


\section{AGRADECIMENTOS}

Machado de Assis, logo à entrada do volume de Várias histórias (1896), que reúne preciosidades literárias como "Um homem célebre", advertia: "O tamanho não é o que faz mal a este gênero de histórias, é naturalmente a qualidade; mas há sempre uma qualidade nos contos, que os torna superiores aos grandes romances, se uns e outros são medíocres: é serem curtos". Sem a ironia do Bruxo do Cosme Velho, porque sem tamanho gênio, torço para que a virtude da brevidade valha também para teses... Mas, aqui, na tão protocolar quanto justa tarefa de agradecer, não cabe economizar.

Formar-se, viver, sobreviver - nada seria possível sem o apoio e a compreensão de muita gente. Os nomes citados abaixo, como de costume, não exaurem a lista daqueles que foram importantes para a realização das "tarefas" direta e indiretamente necessárias para a conclusão do doutorado, mas é inevitável assumir o risco do esquecimento involuntário - e muitas vezes cruel - e nomear pessoas que tiraram as pedras do nosso caminho.

Primeiramente, agradeço aos meus familiares, por tudo aquilo que uma família é capaz de fazer e suportar durante os anos de dedicação aos cursos e à tese, em especial à criançada, que não faz ideia de que muito do que se diz aqui é por elas. E, sem mudar de parágrafo, aos meus colegas de escritório, que igualmente não poupam apoio e paciência com um advogado repartido entre mil outras ocupações e preocupações.

Agradeço, também, aos professores que tornaram este período, desde a graduação, cheio de aprendizado e oportunidades. É injusto destacar um ou outro, mas menciono a atenção especial e o incentivo recebido dos Profs. Jorge Luiz Souto Maior e Luis Fernando Massonetto quando da realização do exame de qualificação.

Aos meus colegas de Faculdade de Direito de São Bernardo do Campo: a todos homenageio na pessoa da Profa. Eliana Borges Cardoso, incansável e decisiva apoiadora deste aluno desde o primeiro ano da graduação, responsável, numa medida que ela dificilmente admitiria, pelos principais passos dados até aqui.

Aos meus colegas de Facamp: a todos homenageio na pessoa do Prof. Alaôr Caffé Alves, mestre de todos nós, pelo apoio, pelo ensino e pela disposição exemplar à reflexão e aos debates. É incrível como parece ser o mais jovem de todos nós!

Aos amigos que tornaram esses anos de FDUSP mais felizes: ao DJDH, ao José Antonio, Josué, Ariani, Edu, Miya, Renan, Silvio, Vinicius, Kashiura e Akamine; aos três 
últimos, também pelos intermináveis seminários na Rodovia dos Bandeirantes e, agora, pelo desafio de dar vida aos Cadernos de Pesquisa Marxista do Direito.

A todos os amigos, das mesas menos acadêmicas possíveis, tão instrutivas quanto salutares, aos quais homenageio nas pessoas dos corintianos Kleber e Reynaldo.

Agradeço ainda aos funcionários das instituições em que passei os últimos anos: Faculdade de Direito da USP, Faculdade de Direito de São Bernardo do Campo e Facamp, onde sempre encontrei pronta atenção às necessidades mais variadas.

Por último, o especial agradecimento ao meu orientador, Prof. Eduardo C. B. Bittar, exemplo mais bem acabado de acadêmico e pensador engajado nas lutas de nossa época, que estimula quem está ao seu redor seja com a disposição permanente para dialogar, seja pelo exemplo que dá com seu trabalho e, se não bastasse, intensa amizade.

O trabalho está só começando, Professor! Sigamos. 
Sendo esta a tendência das coisas neste sistema, quererá isto dizer que a classe operária deverá renunciar à sua resistência contra as investidas do capital e abandonar as suas tentativas de tirar o melhor proveito das oportunidades ocasionais para a sua melhoria temporária?

Se o fizesse seria degradada a uma massa nivelada de miseráveis domesticados sem salvação. [...] Cedendo cobardemente no seu conflito de todos os dias com o capital, certamente que se desclassificariam para o empreendimento de qualquer movimento mais amplo.

Karl Marx

Porque o capital depende, talvez hoje mais que nunca, de um sistema global de Estados, as lutas verdadeiramente democráticas - entendidas como lutas para trocar o equilíbrio de poder de classe tanto dentro como fora do Estadopodem chegar a ter um efeito muito maior que em épocas anteriores.

Ellen Meiksins Wood 


\section{SUMÁRIO}

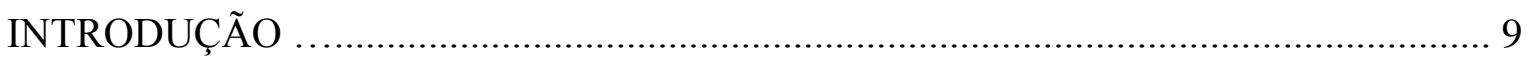

1. IDEOLOGIA: AFIRMAÇÃO DE UM CONCEITO ……………………………....... 18

1.1. Primórdios de um conceito ........................................................................ 18

1.2. A ideologia nas obras de Marx ............................................................... 19

1.3. A ideologia depois de Marx ...................................................................... 30

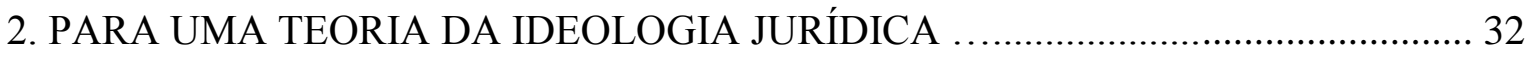

2.1. O debate sobre direito e ideologia ............................................................. 32

2.2. Ambiguidade do direito: abertura e estímulo à resistência .............................. 36

2.3. Uma teoria da ideologia jurídica ............................................................... 50

3. DIREITOS SOCIAIS E NEOLIBERALIZAÇÃO ………………………………....... 54

3.1. Direito e política na Constituição de 1988 ........................................................ 54

3.2. Neoliberalismo e reestruturação produtiva ………………………………..... 58

3.3. Lutas cotidianas e conscientização de classe ..................................................... 64

3.4. Radicalização dos direitos sociais ................................................................ 69

CONSIDERAÇÕES FINAIS ................................................................................... 76

ANEXO: UMA REFLEXÃO SOBRE MARXISMO E DIREITOS HUMANOS ............ 79

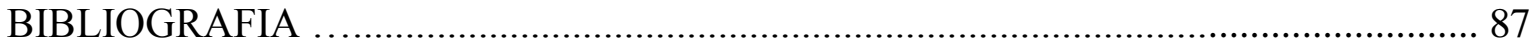

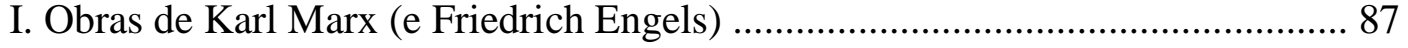

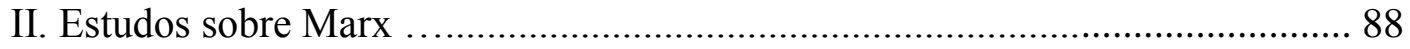

III. Sobre o mundo do trabalho ...................................................................... 90

IV. Filosofia, teoria e demais obras jurídicas ....................................................... 93

V. Outras obras consultadas ............................................................................ 97

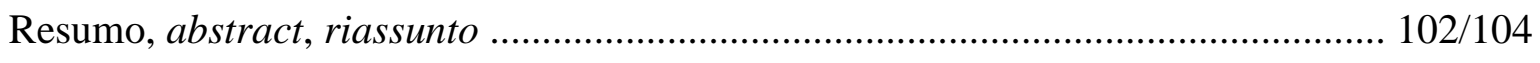




\section{INTRODUÇÃO}

Talvez não adiante pedir que esta tese seja lida em chave otimista, mas ao menos é importante admitir que assim foi escrita. Seus leitores, marxistas ou não, é bem provável que fiquem surpresos ou indignados com uma mesma constatação: tem-se aqui uma teoria crítica do direito, que se reivindica marxista, mas se anima com o potencial transformador do direito. Entretanto, para que tal otimismo não seja imperdoável, deve-se notar: aqui se afirma que o direito terá tal poder independentemente de cumprir seus efeitos jurídicos, isto é, o principal favor que o direito pode oferecer à transformação social passa ao largo de serem irrealizáveis as muitas vezes profundas mudanças nele projetadas e, justamente por esta razão, não deve ser subestimado como campo de lutas políticas.

O presente trabalho tem por objetivo demonstrar como o direito, ao passo que exerce função essencial como instrumento de dominação entre classes sociais, apresenta-se também como importante instrumento de resistência política da classe trabalhadora. Tal importância ultrapassa a simples efetividade das normas no campo jurídico e ganha especial relevância na forma como se traduzem juridicamente as lutas de classes, o que faz com que as reivindicações políticas transformadas em direitos, por mais que em grande medida se neutralizem de acordo com os interesses hegemônicos, permaneçam no horizonte político da sociedade, alimentando a tensão por transformação social.

O estudo considera que, no contexto do Estado de Direito, os grupos sociais lutam para transformar suas reivindicações em direitos e, depois, lutam pela efetivação desses direitos, como etapas distintas e de modo mais individualizado do que coletivo. E o fato de que essas duas "etapas" sejam autônomas é estratégico para a neutralização do potencial político das forças sociais interessadas na transformação para a qual tais direitos apontam. Contudo, ambas as etapas - a reivindicação de direitos e a luta por sua efetivação - têm potencial transformador, pois podem acender, para além do caráter individualmente paliativo dos direitos, um novo nível de tensão política entre as classes sociais, em que o direito como forma de "pacificação social" tem sua legitimidade abalada e, no limite, pode ser substituído por outras formas de luta: não mais a "luta por direitos", mas a luta da classe dominada diretamente pela satisfação de seus interesses.

É neste sentido que o estudo da função exercida pelo direito no conjunto da ideologia social assume radical importância, pois a recorrente negação de efetividade aos 
direitos é capaz de abrir fraturas significativas na ideologia dominante, ao passo que fracassam as soluções individuais oferecidas pelo direito e, consequentemente, a crítica ganha espaço na consciência social, junto à necessidade de buscar soluções efetivas para os problemas decorrentes do desenvolvimento da sociedade capitalista.

Este trabalho identifica que o direito é necessariamente ambíguo na forma como absorve e "soluciona" os conflitos sociais, pois as previsões de transformação social integram a aparência necessária do papel que este mesmo direito exerce na conservação da sociedade de classes. No entanto, dessa ambiguidade decorre dialeticamente um potencial de resistência política, que, diante da importância assumida pelo direito na conformação e manutenção das relações sociais necessárias à reprodução do capital, assiste também a um correspondente aumento de sua importância como espaço de luta política.

Isto se deve à ambiguidade que tantos autores já identificaram na Constituição, esta que não se resume a uma questão textual, mas, nas palavras de Plínio de Arruda Sampaio, "se traduz, por um lado, em reforçar a ordem burguesa, na medida em que constitucionaliza o direito de propriedade, a livre iniciativa, a herança, a livre concorrência - institutos basilares do regime capitalista; por outro lado, ordena a essa burguesia que garanta a existência de uma sociedade livre, justa e solidária, capaz de garantir a soberania nacional, erradicar a pobreza e reduzir as desigualdades sociais e regionais. Trata-se, pois, de uma Carta social-democrata com tonalidades nacionalistas" $"$.

No entanto, é nesta ambiguidade que o mesmo deputado constituinte encontra razões para afirmar que, por mais que tenham sido em grande parte ilusórios os pressupostos da Constituição no combate ao movimento do capital internacional e das novidades da ordem política que o novo modelo econômico exigia, é ela ainda o suporte de “dispositivos constitucionais que asseguram a vários setores populares melhores condições de resistência contra o avanço do capitalismo neocolonial".

É justamente neste ponto que se dá a relação dialética que este trabalho detalhará: ambiguidade e resistência. Bem sabemos, a partir do que tem sido ensinado pelos críticos do direito, que o monopólio da violência pelo Estado, por mais que seja estruturado, não permite que as forças dominantes abram mão do domínio ideológico, que representa, por assim dizer, grande economia de força estatal para conter os descontentes. Mas, por outro

\footnotetext{
${ }^{1}$ SAMPAIO, "Fruto de uma ilusão", in Versus (Revista de Ciências Sociais Aplicadas do CCJE/UFRJ), dossiê 20 anos de Constituição: o pacto pós-ditadura, dezembro de 2008, pp. 18-19.
} 
lado, é reducionismo afirmar que todos os projetos constitucionais de melhoria da sociedade são apenas um jogo de cena para entreter a massa ignara...

Aposta-se, aqui, que esta relação é mais complexa do que pode parecer à primeira investida crítica: o texto constitucional não é completamente dominado pela lógica destrutiva do capital, tampouco seria possível deter na sociedade os influxos reais que as promessas eventualmente ilusórias poderiam desencadear. Noutras palavras: a Constituição é ambígua em sua relação com a realidade e esta ambiguidade é a porta para a resistência de grupos sociais que tendem a devolver o direito para a política.

A par disso, uma teoria da ideologia jurídica, como a que aqui se pretende formular, exige a revelação dos nexos profundos entre direito e sociedade. Mais especificamente, tal teoria somente é possível se a relação entre o direito vigente e uma determinada sociedade for considerada dialeticamente, com influências mútuas: até que ponto o direito reflete (direta ou invertidamente) a sociedade, até que ponto ele consegue transformá-la, até que ponto ele atua para mantê-la sob determinada configuração.

Esta tarefa coloca diante da teoria diversos desafios metodológicos, para a apreensão de um objeto que, ao mesmo tempo em que aparece no direito, precisa ser contrastado na economia política e desmascarado na política propriamente dita. Não são poucas as vozes que têm denunciado ultimamente o uso do direito na despolitização de questões sociais (criminalização dos movimentos sociais, judicialização de questões constitucionais etc.). Afinal, este tem sido seu principal papel político?

Não basta afirmar que o direito é político (ou que é usado politicamente) por trás de suas propaladas neutralidade e racionalidade. Mais que isso, é necessário identificar como a forma direito tem sido - originalmente e em sua afirmação histórica - um modo próprio do fazer política, ainda mais quando a luta política, marcadamente no chamado Estado de direito, consiste em grande parte na busca por direitos, isto é, em transformar reivindicações políticas em direito positivo, em leis escritas.

Em poucas palavras, o objetivo deste trabalho é investigar o papel específico exercido pelo direito como ideologia no quadro geral da ideologia social e afirmar a existência de uma forma de dominação política que se dá por meio do direito e, mais ainda, que apenas por meio do direito é possível, demonstrando, contudo, que esta forma de dominação é ambígua e, em certa medida, serve à sua própria contestação.

Estudar o direito como ideologia, aqui, não significa dizer que o direito como um todo pode ser reduzido à ideologia. O direito tem uma materialidade específica e sua 
coercitividade não é apenas uma ideia. Impossível, portanto, sustentar qualquer reducionismo ou determinismo na relação entre direito e sociedade. Entretanto, deve-se reconhecer que a ideia de direito é politicamente mais poderosa que as próprias leis em que ela se materializa, o que se confirma pelo fato de que o descrédito de muitas leis dificilmente se converte em descrédito do direito como um todo.

Por um lado, as mais diversas forças sociais, das mais conservadoras às mais progressistas, incluindo algumas que possuem discurso revolucionário, lutam dentro do direito (com interpretações diversas para a mesma lei) e para entrar no direito (por alterações legislativas que contemplem seus interesses), sem jamais questionar se a forma jurídica em si mesma já não traz o embrião da sua derrota. Obviamente, a banda conservadora não tem porque questionar a forma jurídica, que ao estabelecer a igualdade formal favorece naturalmente a parte forte na desigualdade real, mas os movimentos que pretendem alguma transformação social certamente deveriam fazê-lo.

Neste sentido, quando a reivindicação social é no sentido da conquista de direitos, isto significa a aceitação das "regras do jogo jurídico". Ocorre, neste momento, uma espécie de passagem da participação para a representação, no plano institucional, favorecendo a manipulação dos interesses ante a desmobilização da força social que fez de determinada reivindicação um direito. Frise-se aqui esta característica da relação entre direito e política: quando um determinado projeto político atinge o status de direito, ao passo que ele parece ter recebido a forma que mais favorecerá sua realização, a tendência é que se afaste de sua força originária e passe a ser apenas direito. Ou seja, amplos projetos políticos, quando viram direitos, cristalizam-se como normas, mas ficam sujeitos à instabilidade (modificabilidade) própria das leis.

Entretanto, afirmar apenas o que ocorre neste sentido - da política para o direito não dá conta da complexidade da relação, pois o fato de que existam normas abrigando as reivindicações de diversos grupos sociais significará, em muitos casos, que aqueles direitos serão cobrados e, ao enfrentar maior ou menor resistência das autoridades, tal cobrança pode modificar profundamente a relação entre Estado e sociedade.

Com o estudo dos direitos sociais, que advêm de/corporificam um projeto político, mas integram a Constituição Federal como normas, é possível perceber como sua função ideológica é ambígua. Mas esta não é, em nada, uma novidade da Constituição de 1988. É evidente, historicamente, na relação entre a positivação do direito e a instalação do capitalismo: a transformação dos "direitos naturais" em "direitos positivos", que serviria 
para consolidar tais direitos, veio ao encontro da flexibilidade demandada pela ascensão do capitalismo, livrando-o da rigidez axiológica do direito consuetudinário para tornar mais maleáveis as regras da sociedade, favorecendo o fluxo mercantil.

O que se verifica, assim, é que não basta reconhecer a importância de certas normas jurídicas para a afirmação do capitalismo (mesmo se se falar na garantia absoluta da propriedade privada ou na igualdade perante a lei). É necessário perceber que a própria ideia de direito (direito positivo) é constitutiva do modo de produção capitalista, não apenas pela materialidade das leis, mas pela aceitação do direito como forma eficaz de organização do convívio social e abrigo dos valores comuns.

Ressalta daí, com clareza, para além da coercitividade das leis, o papel do direito como ideologia, como parte determinante da consciência social. A sequência deste trabalho, portanto, depende do estudo do papel da ideologia na manutenção da sociedade de classes, o que se deve à obra de Karl Marx (1818-1883).

É bem verdade que a história do conceito de ideologia começa antes de Marx, mas não há dúvida de que sua obra é a grande responsável por colocar a ideologia em destaque no debate intelectual (filosófico, político, econômico, sociológico, artístico) dos últimos 100 anos. Estudiosos da obra de Marx e do marxismo costumam reconhecer que tal conceito apresenta mudanças importantes na própria obra marxiana, mas com variações muito menores do que aquelas existentes entre as obras de alguns dos principais marxistas, como Lenin, Lukács, Gramsci e Althusser².

O primeiro uso que Marx faz da noção de ideologia está nos textos do início dos anos 1840, principalmente na Crítica da filosofia do direito de Hegel (1843) e nos Manuscritos econômicos-filosóficos (1844). Em formulação já muito mais desenvolvida, a ideologia está no centro de sua intensa colaboração com Engels, de que resulta fundamentalmente $A$ ideologia alemã (1845-1846). Depois, ainda que o nome ideologia praticamente desapareça ${ }^{3}$, continua determinante para a crítica de Marx ${ }^{4}$, desde os

\footnotetext{
${ }^{2}$ É importante notar, a propósito, que grande parte do debate marxista sobre o conceito de ideologia ocorreu sem que fosse conhecida a obra em que Marx, em conjunto com Engels, definiu mais claramente seu conceito de ideologia, pois a primeira edição d'A ideologia alemã é de 1921.

3“A palavra ideologia quase que desaparece desses textos. Não obstante, a pertinência da análise econômica de Marx para o conceito evidencia-se com o uso constante e a reelaboração da noção de inversão" - Jorge Larrain, "Ideologia", in BOTTOMORE, Dicionário do pensamento marxista, p. 184.

4 “Marx já havia chegado à conclusão de que, se algumas idéias deformavam ou 'invertiam' a realidade, era porque a própria realidade estava de cabeça para baixo. Mas essa relação aparecia de maneira direta, nãomediada. A análise específica das relações sociais capitalistas leva-o à conclusão mais avançada de que a conexão entre 'consciência invertida' e 'realidade invertida' é mediada por um nível de aparências que é constitutivo da própria realidade. Essa esfera de 'formas fenomenais' é constituída pelo funcionamento do
} 
Grundrisse (1857-1858), passando pela Contribuição à crítica da economia política (1859) e chegando ainda mais elaborada no primeiro livro d'O capital (1867).

A intenção, na parte inicial desta tese, é identificar um conceito de ideologia condizente com o desenvolvimento do pensamento de Marx, buscando as contribuições dos estudiosos de sua obra e de outros filósofos, revelando a importância que a ideologia (em sua dimensão negativa, de crítica das representações sociais ilusórias, ou na dimensão positiva, segundo a qual o próprio marxismo é uma ideologia para a emancipação social) ainda apresenta na sociedade e, consequentemente, nas ciências sociais.

Na trilha de Marx, de que as ideias da classe economicamente dominante são as ideias dominantes numa determinada época, deve-se notar que a tão propagandeada ideologia do fim das ideologias empenha-se em esconder o seu contrário, que a dominação econômica hoje depende de uma carga ainda maior de ideologia:

\footnotetext{
Paradoxalmente, portanto, a excessiva orientação metodológica de tais abordagens, embora ostensivamente 'antiideológicas', manifesta, de fato, uma adesão ideológica muito mais intensa característica de épocas de forte conflito social - aos imperativos e aos valores estruturais da ordem estabelecida. Ou seja, uma adesão mais intensa e de maior consciência de classe do que aquilo que se pode ver, geralmente, em circunstâncias históricas de menor polarização ${ }^{5}$.
}

No caso do direito, então, em que a negação da adesão ideológica sempre foi radical sob o argumento da racionalidade técnica, é ainda mais instigante a tarefa de desvendar como o discurso da inexorabilidade da política econômica neoliberal explicita uma determinada consciência de classe, que se aproveita da maleabilidade do direito para garantir a sua imposição sobre outras políticas possíveis.

Como as ilusões da ideologia estão sustentadas por contradições reais, Marx deixa claro que o combate às ideias falsas não basta por si. É preciso que se solucione a contradição real por meio de uma ação transformadora sobre a realidade. A mudança, portanto, do papel que a ideia de direito exerce sobre a sociedade depende de uma mudança estrutural mais profunda, mas isto não significa que sejam inúteis os embates no campo da ideologia jurídica, denunciando as limitações que o direito mesmo contém para sua efetivação contra os interesses economicamente dominantes.

mercado e da concorrência nas sociedades capitalistas, e é uma manifestação invertida da esfera da produção, o nível subjacente das 'relações reais"” - Jorge Larrain, verbete "Ideologia", in Tom BOTTOMORE (ed.), Dicionário do pensamento marxista, p. 184.

${ }^{5}$ István MÉSZÁROS, O poder da ideologia, p. 319. 
É indispensável, neste ponto, a advertência de Terry Eagleton:

\begin{abstract}
Nenhum radical que examine friamente a tenacidade e a penetração das ideologias dominantes pode sentir-se esperançoso quanto ao que seria necessário para afrouxar seu domínio letal. Mas há um lugar, acima de todos, em que tais formas de consciência podem ser transformadas, quase literalmente, da noite para o dia, e esse é a luta política. Isso não é uma carolice de esquerda, mas um fato empírico. Quando homens e mulheres, engajados em formas locais, inteiramente modestas de resistência política, vêem-se trazidos, pelo ímpeto interior de tais conflitos, para o confronto direto com o poder do Estado, é possível que sua consciência política seja definitiva e irreversivelmente alterada. Se uma teoria da ideologia tem algum valor, este consiste em auxiliar no esclarecimento dos processos pelos quais pode ser efetuada praticamente tal libertação diante de crenças letais. ${ }^{6}$
\end{abstract}

Se denunciar o caráter de classe do direito é uma tarefa a que a corrente crítica em geral, e marxista, especialmente - persistente na filosofia jurídica tem dedicado todas suas armas, as mudanças recentes da sociedade, acentuando cada vez mais as contradições sob a pregação de que "não há alternativas", fazem com que esta tarefa se apresente atualmente renovada, exigindo nova investida crítica capaz de compreender a complexidade atual da relação entre direito e sociedade, de que a Constituição é exemplar.

Para tanto, este tese percorre um itinerário teórico dividido em três movimentos. Inicialmente, estuda a forma como se constitui e complexifica a noção de ideologia nas obras de Karl Marx, desde as obras iniciais até sua reflexão mais madura. O segundo movimento é dedicado a localizar o papel exercido pelo direito no conjunto da ideologia social e indaga as possibilidades de uma teoria da ideologia jurídica. Em seu terceiro e último movimento, a fim de demonstrar concretamente a problemática da tese, dedica-se à investigação da relação entre ambiguidade e resistência no caso dos direitos sociais, em especial os direitos dos trabalhadores previstos na Constituição brasileira de 1988, cuja vigência se dá sob forte pressão neoliberal. Neste passo, aproveita-se fartamente do diálogo com a sociologia crítica do trabalho, no intuito de verificar como as lutas concretas dos trabalhadores transitam entre o direito, a política e a ideologia.

Neste ponto deve ser feita uma distinção relevante: os juristas não costumam buscar fora do direito a compreensão das questões "jurídicas", mas a legislação é alterada corriqueiramente em razão de estudos realizados por perspectivas não-jurídicas.

\footnotetext{
${ }^{6}$ Terry EAGLETON, Ideologia: uma introdução, p. 195.
} 
Obviamente, o direito é uma pequena fresta da ciência social, que permite enxergar apenas uma parcela do mundo e sempre vai depender de outras perspectivas. Mas o problema resultante do enclausuramento dos juristas em suas próprias questões é que, quando precisam fundamentar a interpretação da lei fora do direito, acabam por aceitar, sem questionamentos, conclusões superficiais e duvidosas de outras áreas.

No tocante aos direitos sociais, que interessam ao presente estudo, o efeito desta conduta é devastador. Têm-se consagrado, com base em surrados slogans do discurso econômico neoliberal, que ostentam a (falsa) neutralidade da ciência e a (falsa) evidência das estatísticas, formas de antecipar a derrubada das garantias constitucionais e legais ainda vigentes, que deixam de ser aplicadas ou são violentamente "flexibilizadas" sob o argumento de que não são adequadas ao capitalismo em sua etapa atual.

Os direitos sociais são espancados, diga-se, por simples cálculo. Segundo seus inimigos, eles custam caro demais para as empresas, para o Estado, para o contribuinte, e esta é a razão suficiente para que sejam desmontados, pouco importando a gravidade das necessidades que eles buscam suprir (alimentação e saúde, por exemplo). Os críticos da previsão constitucional de direitos sociais, que entendem que o Estado deveria deixar os indivíduos lutarem com suas próprias armas pela sobrevivência, defendem que o direito do trabalho, por exemplo, causa mais prejuízos do que benefícios aos trabalhadores, sendo melhor para todos que a economia transcorra segundo a força dos próprios agentes. Entretanto, Gilberto Bercovici e Luís Fernando Massonetto, ao estudar o modelo de Constituição dirigente adotado no Brasil, notam uma contradição:

A crítica feita à constituição dirigente pelos autores conservadores diz respeito, entre outros aspectos, ao fato de a constituição dirigente "amarrar" a política, substituindo o processo de decisão política pelas imposições constitucionais. Ao dirigismo constitucional foi imputada a responsabilidade maior pela "ingovernabilidade". O curioso é que são apenas os dispositivos constitucionais relativos a políticas públicas e direitos sociais que "engessam” a política, retirando a liberdade de atuação do legislador. $\mathrm{E}$ os mesmos críticos da constituição dirigente são os grandes defensores das políticas de estabilização e de supremacia do orçamento monetário sobre as despesas sociais. ${ }^{7}$

Contradições como esta tornam a discussão ainda mais relevante e fazem crescer a curiosidade do pesquisador sobre as ambiguidades da Constituição e as possibilidades de

\footnotetext{
${ }^{7}$ Gilberto BERCOVICI, Luís Fernando MASSONETTO, “A Constituição Dirigente Invertida: a blindagem da constituição financeira e a agonia da constituição econômica”, pp. 132/133.
} 
luta política que ela envolve, limita, neutraliza, anula ou até potencializa, porque é de capital importância para a teoria jurídica entender como a forma constitucional pode sobreviver à defesa simultânea de garantias antagônicas, aparentemente sem comprometer sua função política, tampouco seu papel na regulação social.

No período de hegemonia das concepções de democracia formal e do intocável Estado de Direito, em que a política é feita através do direito (ou ainda: em que o direito delimita o campo de atuação da política, reduzindo todas as reivindicações sociais a "lutas por direitos"), ressalta-se a importância de um estudo crítico sobre o direito constitucional, tendo em vista que a afirmação do Estado de Direito é marcada por um duplo movimento: no plano formal, a aparente ampliação do espectro de interesses sociais que vão sendo progressivamente contemplados (até mesmo em contradição com as necessidades de reprodução do capital e de sustentação do próprio Estado); no plano real, contudo, a obstaculização crescente das formas de organização dos grupos sociais, impondo-lhes que suas reivindicações sejam feitas por dentro do direito.

Como já dito, a Constituição de 1988 surgiu como grande restauradora (ou inventora?) da democracia e do Estado de Direito no Brasil e, desde a constituinte, enfrenta os influxos da neoliberalização no país, o que se agravou de lá para cá. Por ser uma Carta que serviu como pacto entre as diversas forças sociais organizadas nos 1980 no Brasil (anos em que se formam organizações representativas como o Partido dos Trabalhadores, a Central Única dos Trabalhadores e o Movimento dos Trabalhadores Rurais Sem Terra), as suas previsões abraçam vertentes ambíguas - e é exatamente neste campo que ela serve como peça de resistência, ainda hoje, para a classe trabalhadora.

Por fim, um esclarecimento quanto ao título e, de certo modo, a antecipação das conclusões do trabalho. Optei pelos termos ambiguidade e resistência, em vez de algo como contradição e revolução, porque acredito que o nível dos conflitos ideológicos e políticos que se colocam no direito não atinge a profundidade de uma contradição concreta no sistema, tampouco permitem uma transformação completa das estruturas sociais. O que interessa, aqui, é perceber as possibilidades de elaboração de lutas que, mirando contra o direito, visam atingir, na verdade, alvos muito mais ambiciosos. 


\section{IDEOLOGIA: AFIRMAÇÃO DE UM CONCEITO}

\subsection{Primórdios de um conceito}

Ideologia está longe - muito longe - de ser um conceito unívoco. É assim desde seus primeiros usos e ainda hoje. Em Destutt de Tracy, responsável pela criação do termo em sua obra Élements de Idéologie, de 1801, ideologia pertencia à zoologia e se dedicava à "análise das sensações e das ideias". Logo depois, no entanto, quando fíca claro que o estudo proposto por De Tracy poderia revelar aspectos da realidade incômodos à manutenção de seu poder, Napoleão usará o termo "ideólogos" em sentido depreciativo, associando as pesquisas dos "ideologistas" a uma forma muito peculiar de subversão: os ideólogos destruíam as ilusões e, assim, impediam a "felicidade dos povos". Napoleão chega até a culpá-los pelo fracasso de seus projetos políticos ${ }^{8}$.

Napoleão, portanto, já usa a expressão em dois sentidos em certa medida contrários: ao mesmo tempo em que acusa os ideólogos de não serem realistas do ponto de vista político, ele reconhece que o trabalho dos ideólogos atinge as ficções de que depende seu projeto político. A relação entre real, ilusório e dominação, que depois será retomada por todos os estudiosos da ideologia a partir de Marx, já aparece com alguma clareza na crítica de Napoleão aos ideólogos e, talvez por isso, é que o sentido de ideólogos como "metafísicos abstratos"9 será difundido muito mais do que o sentido original de ideologia (estudo das ideias) para Destutt de Tracy e seus colegas.

Terry Eagleaton chama a atenção para um destino interessante das palavras terminadas por "-logia": ao passo que surgem designando o estudo de algo, rapidamente passam a ser tomadas pelo seu próprio objeto de estudo ${ }^{10}$. Como no caso de ecologia ou de metodologia, que são comumente utilizadas com o sentido de ecossistema ou de método, quando na verdade estes são apenas os objetos daquelas ciências.

Com a ideologia não foi diferente: surgida com a intenção de ser o estudo das ideias, rapidamente passa a designar o próprio conjunto de ideias. É com este sentido que a expressão é utilizada atualmente, seja quando se refere ao conjunto de ideias ilusórias (religiosas, morais, filosóficas, jurídicas etc.) sobre a realidade, seja quando - na esteira de

\footnotetext{
${ }^{8}$ Acompanho aqui o relato detalhado de Terry EAGLETON, Ideologia, pp. 67-71.

${ }^{9}$ Michael LÖWY, As aventuras de Karl Marx contra o Barão de Münchausen, p. 10.

${ }^{10}$ Terry EAGLETON, Ideologia, p. 65.
} 
Lenin - se refere ao "conjunto das concepções de mundo ligadas às classes sociais, incluindo o marxismo". Como afirma Michael Löwy, "é com esta significação que o termo entrou na língua corrente dos militantes marxistas ('luta ideológica', 'ideologia revolucionária', 'formação ideológica' etc.)"11.

Antes, no entanto, de enfrentar as apropriações e transformações do conceito de ideologia feitas pelos marxistas, é importante se debruçar sobre os usos que a noção de ideologia tem nas obras do próprio Marx, percebendo como ela aparece, muitas vezes sem ser nomeada, como uma ferramenta essencial nas precisas e diversas investigações do autor de $O$ Capital sobre as ilusões gestadas pelas contradições sociais no capitalismo e necessárias para a manutenção deste mesmo sistema contraditório.

\subsection{A ideologia nas obras de Marx}

Nesta parte, a fim de demonstrar com as próprias e sempre precisas palavras de Marx como se constrói e depois é completamente incorporada a crítica da ideologia, farei uso extensamente de citações de seus textos, espalhados durante as quatro décadas decisivas de produção teórica e atividade política do autor d’ $O$ capital.

Já na sua crítica inaugural à filosofia do Direito de Hegel (1843), a tarefa de Marx é preponderantemente a de flagrar diversas "inversões", "abstrações", "idealizações", "mistificações" cometidas pela interpretação hegeliana do Estado, do direito e da política. Se, para Hegel, a "Ideia" tem papel ativo, se ela $f a z$, Marx demonstra que, na verdade, ela é feita, ela é produto. A fim de ilustrar a recorrência de tais afirmações, podemos destacar as seguintes: "inversão do subjetivo no objetivo e do objetivo no subjetivo"12, "conversão necessária do empírico em especulativo e do especulativo no empírico"13, "o universal aparece por toda parte como algo de particular, de determinado"14, "Hegel idealiza a burocracia e empiriciza a consciência pública"15, "Ele faz da causa o efeito, e do efeito a causa, do determinante o determinado e do determinado o determinante" ${ }^{, 16}$.

O Marx de A questão judaica (1843) continua ainda dedicado a investigar diversas inversões. Pode-se citar o seguinte exemplo que antecipa a noção de ideologia:

\footnotetext{
${ }^{11}$ Michael LÖWY, As aventuras de Karl Marx contra o Barão de Münchausen, p. 10.

${ }^{12}$ Karl MARX, Crítica da Filosofia do Direito de Hegel, p. 58.

${ }^{13}$ Karl MARX, Crítica da Filosofia do Direito de Hegel, p. 59.

${ }^{14}$ Karl MARX, Crítica da Filosofia do Direito de Hegel, p. 59.

${ }^{15}$ Karl MARX, Crítica da Filosofia do Direito de Hegel, p. 79.

${ }^{16}$ Karl MARX, Crítica da Filosofia do Direito de Hegel, p. 115.
} 
Nenhum dos chamados direitos humanos ultrapassa, portanto, o egoísmo do homem, do homem como membro da sociedade burguesa, isto é, do indivíduo voltado para si mesmo, para seu interesse particular, em sua arbitrariedade privada e dissociado da comunidade. Longe de conceber o homem como um ser genérico, estes direitos, pelo contrário, fazem da própria vida genérica, da sociedade, um marco exterior aos indivíduos, uma limitação de sua independência primitiva. $\mathrm{O}$ único nexo que os mantém em coesão é a necessidade e o interesse particular, a conservação de suas propriedades e de suas individualidades egoístas. ${ }^{17}$

Chama a atenção de Marx, então, a forma como os direitos humanos invertem, na aparência, a proteção do indivíduo burguês como proteção de todos os homens. Sua crítica aponta, em resumo, que "a vida política é tão somente a garantia dos direitos do homem individual" ". Mais à frente, Marx afirma que ocorre uma "ilusão ótica" na consciência dos emancipadores (revolucionários) ao tomar "o fim como meio e o meio como fim".

$\mathrm{Na}$ Introdução (1843/44) à Crítica da filosofia do direito de Hegel, em que diversos parágrafos são voltados à crítica da religião, Marx apresenta importantes elementos que antecipam a concepção de ideologia a que se dedicou posteriormente:

o homem faz a religião, a religião não faz o homem. E a religião é de fato a autoconsciência e o sentimento de si do homem, que ou não se encontrou ainda ou voltou a se perder. Mas o homem não é um ser abstrato, acocorado fora do mundo. O homem é o mundo do homem, o Estado, a sociedade. Este Estado e esta sociedade produzem a religião, uma consciência invertida do mundo, porque eles são um mundo invertido. A religião é a teoria geral deste mundo, o seu resumo enciclopédico, a sua lógica em forma popular, o seu point d'honneur espiritualista, o seu entusiasmo, a sua sanção moral, o seu complemento solene, a sua base geral de consolação e de justificação. É a realização fantástica da essência humana, porque a essência humana não possui verdadeira realidade. Por conseguinte, a luta contra a religião é, indiretamente, a luta contra aquele mundo cujo aroma espiritual é a religião. ${ }^{19}$

Repare-se, aí, como a noção de inversão é central para o argumento de Marx, destacando as noções de "consciência invertida" e "mundo invertido". A propósito, vale citar o comentário de Jorge Larrain: “A inversão religiosa compensa, no espírito, uma

\footnotetext{
${ }^{17}$ Karl MARX, A questão judaica, p. 36.

${ }^{18}$ Karl MARX, A questão judaica, p. 37.

19 "Crítica da filosofia do direito de Hegel - Introdução", in Karl MARX, Crítica da filosofia do direito de Hegel, p. 145.
} 
realidade deficiente, reconstitui na imaginação uma solução coerente que está além do mundo real, para compensar as contradições desse mundo real"20.

Desdobra-se daí o que se encontra nos Manuscritos econômico-filosóficos (1844):

a externalidade (Äusserlichkeit) do trabalho aparece para o trabalhador como se [o trabalho] não fosse seu próprio, mas de um outro, como se [o trabalho] não lhe pertencesse, como se ele no trabalho não pertencesse a si mesmo, mas a um outro. Assim como na religião a auto-atividade da fantasia humana, do cérebro e do coração humanos, atua independentemente do indivíduo e sobre ele, isto é, como uma atividade estranha, divina ou diabólica, assim também a atividade do trabalhador não é a sua auto-atividade. Ela pertence a outro, é a perda de si mesmo ${ }^{21}$

Já em A Sagrada Família (1844), em parceria com Engels, a concepção de ideologia e os confrontos entre ideia e realidade são postos de forma mais aguda:

Segundo a Crítica crítica, todo mal reside apenas no modo de 'pensar' do trabalhador. É certo que os trabalhadores ingleses e franceses formaram associações nas quais não são apenas suas necessidades imediatas enquanto trabalhadores, mas também suas necessidades enquanto homens as que formam o objeto de seus mútuos ensinamentos e nas quais se exterioriza, ademais, uma consciência bastante ampla e cuidadosa sobre a força 'monstruosa' e 'imensurável' que nasce de sua cooperação. Mas esses trabalhadores massivos e comunistas, que atuam nos ateliers de Manchester e Lyon, por exemplo, não crêem que possam eliminar, mediante o 'pensamento puro', os seus senhores industriais e a sua própria humilhação prática. Eles sentem de modo bem doloroso a diferença entre ser e pensar, entre consciência e vida. Eles sabem que propriedade, capital, dinheiro, salário e coisas do tipo não são, de nenhuma maneira, quimeras ideais de seu cérebro, mas criações deveras práticas e objetivas de sua própria auto-alienação, e que portanto só podem e devem ser superadas de uma maneira também prática e objetiva, a fim de que o homem se torne um homem não apenas no pensamento e na consciência, mas também no ser massivo e na vida. A Crítica crítica, pelo contrário, quer fazê-los crer que deixarão de ser trabalhadores assalariados na realidade apenas com o fato de superar em pensamento o pensamento do trabalho assalariado, apenas com o fato de deixar de se considerarem trabalhadores assalariados em pensamento, deixando, de acordo com essa fantasia exagerada, de deixarem-se pagar por sua pessoa. Na condição de idealistas absolutos, de seres etéreos, naturalmente eles poderão viver do éter do pensamento puro depois disso. A Crítica crítica os ensina que eles superam o capital real com o simples domínio da categoria do capital no pensamento, que eles realmente mudam, tornando-se homens reais, se mudarem seu 'eu abstrato' na consciência, desprezando toda a mudança real de sua existência, quer dizer, das condições reais de sua existência, portanto, de seu eu real como se fosse uma mera operação acrítica. O 'espírito', que

${ }^{20}$ Jorge Larrain, "Ideologia”, in BOTTOMORE, Dicionário do pensamento marxista, p. 184.

${ }^{21}$ Karl MARX, Manuscritos econômico-filosóficos, p. 83. 
só vislumbra categorias na realidade, naturalmente também reduz toda a atividade humana e sua práxis a um processo de pensamento dialético da Crítica crítica ${ }^{22}$.

Note-se, aqui, que são diversas obras - de Marx e Engels - de um mesmo período, centradas num certo número de questões e que, principalmente, buscavam demonstrar uma ruptura. Portanto, as críticas aos jovens hegelianos retomam várias das críticas feitas por Marx, desde o ano anterior, ao pensamento do próprio Hegel.

$\mathrm{Na}$ devidamente célebre e principal obra escrita em parceria com Engels, $A$ ideologia alemã (1845/46), os exemplos são fartos, mas indispensáveis. Nas passagens aqui transcritas, fica mais clara, pela primeira vez, a intenção de deduzir teoricamente as ideias que, até então, surgiam de modo pontual em diversas análises:

As idéias da classe dominante são, em cada época, as idéias dominantes, isto é, a classe que é a força material dominante da sociedade é, ao mesmo tempo, sua força espiritual dominante. A classe que tem à sua disposição os meios da produção material dispõe também dos meios da produção espiritual. As idéias dominantes não são nada mais do que a expressão ideal das relações materiais dominantes, são as relações materiais dominantes apreendidas como idéias; portanto, são a expressão das relações que fazem de uma classe a classe dominante, são as idéias de sua dominação. Os indivíduos que compõem a classe dominante possuem, entre outras coisas, também consciência e, por isso, pensam; na medida em que dominam como classe e determinam todo o âmbito de uma época histórica, é evidente que eles o fazem em toda a sua extensão, portanto, entre outras coisas, que eles dominam também como pensadores, como produtores de idéias, que regulam a produção e a distribuição das idéias de seu tempo; e, por conseguinte, que suas idéias são as idéias dominantes da época. ${ }^{23}$

[...] A produção de idéias, de representações, da consciência, está, em princípio, imediatamente entrelaçada com a atividade material e com o intercâmbio material dos homens, com a linguagem da vida real. O representar, o pensar, o intercâmbio espiritual dos homens ainda aparecem, aqui, como emanação direta de seu comportamento material. O mesmo vale para a produção espiritual, tal como ela se apresenta na linguagem da política, das leis, da moral, da religião, da metafísica etc. de um povo. Os homens são os produtores de suas representações, de suas idéias e assim por diante, mas os homens reais, ativos, tal como são condicionados por um determinado desenvolvimento de suas forças produtivas e pelo intercâmbio que a ele corresponde, até chegar às suas formações mais desenvolvidas. A consciência [Bewusstsein] não pode jamais ser outra coisa do que o ser consciente [bewusste Sein], e o ser dos homens é o seu processo de vida real. Se, em toda ideologia, os homens e suas relações aparecem de cabeça para baixo como numa câmara escura, este fenômeno resulta do

\footnotetext{
${ }^{22}$ Karl MARX e Friedrich ENGELS, A Sagrada Família, pp. 65/66. Parte escrita apenas por Marx.

${ }^{23}$ Karl MARX e Friedrich ENGELS, A ideologia alemã [Boitempo], p. 47.
} 
seu processo histórico de vida, da mesma forma como a inversão dos objetos na retina resulta de seu processo de vida imediatamente físico.

Totalmente ao contrário da filosofia alemã, que desce do céu à terra, aqui se eleva da terra ao céu. Quer dizer, não se parte daquilo que os homens dizem, imaginam ou representam, tampouco dos homens pensados, imaginados ou representados para, a partir daí, chegar aos homens de carne e osso; parte-se dos homens realmente ativos e, a partir de seu processo de vida real, expõe-se também o desenvolvimento dos reflexos ideológicos e dos ecos desse processo de vida. Também as formações nebulosas na cabeça dos homens são sublimações necessárias de seu processo de vida material, processo empiricamente constatável e ligado a pressupostos materiais. A moral, a religião, a metafísica e qualquer outra ideologia, bem como as formas de consciência a elas correspondentes, são privadas, aqui, da aparência de autonomia que até então possuíam. Não têm história, nem desenvolvimento; mas os homens, ao desenvolverem sua produção e seu intercâmbio materiais, transformam também, com esta sua realidade, seu pensar e os produtos de seu pensar. Não é a consciência que determina a vida, mas a vida que determina a consciência. No primeiro modo de considerar as coisas, parte-se da consciência como do indivíduo vivo; no segundo, que corresponde à vida real, parte-se dos próprios indivíduos reais, vivos, e se considera a consciência apenas como sua consciência.

Esse modo de considerar as coisas não é isento de pressupostos. Ele parte de pressupostos reais e não os abandona em nenhum instante. Seus pressupostos são os homens, não em quaisquer isolamento ou fixação fantástica, mas em seu processo de desenvolvimento real, empiricamente observável, sob determinadas condições. Tão logo seja apresentado esse processo ativo de vida, a história deixa de ser uma coleção de fatos mortos, como para os empiristas ainda abstratos, ou uma ação imaginária de sujeitos imaginários, como para os idealistas ${ }^{24}$.

[...] Já vimos anteriormente como, entre os filósofos, pôde surgir, mediante a separação entre as idéias e os indivíduos que lhes serviam de base e suas condições empíricas, um desenvolvimento e uma história das simples idéias ${ }^{25}$.

[...] Para os filósofos, uma das tarefas mais difíceis que há é a de descer do mundo do pensamento para o mundo real. A realidade imediata do pensamento é a linguagem. Assim como os filósofos autonomizaram o pensamento, também tiveram de autonomizar a linguagem num reino próprio. Este é o segredo da linguagem filosófica, na qual os pensamentos, como palavras, possuem um conteúdo próprio. O problema de descer do mundo dos pensamentos para o mundo real se converte no problema de descer da linguagem para a vida ${ }^{26}$.

Como afirmou, logo depois, o próprio Marx, as conquistas teóricas d'A ideologia alemã tiveram principalmente a finalidade de auto-esclarecimento para seus autores. Tal afirmação possibilita compreender que o grande número de páginas dedicadas ao tema da

${ }^{24}$ Karl MARX e Friedrich ENGELS, A ideologia alemã [Boitempo], pp. 93-95.

${ }^{25}$ Karl MARX e Friedrich ENGELS, A ideologia alemã [Boitempo], p. 319.

${ }^{26}$ Karl MARX e Friedrich ENGELS, A ideologia alemã [Boitempo], p. 429. 
ideologia acabou por se tornar um instrumento completamente incorporado ao conjunto de armas da crítica que fariam daí em diante. Esta é a razão, certamente, para que a ideologia - como termo específico - tenha praticamente desaparecido da obra de Marx, que também não dedicará outras páginas à sua explanação teórica.

Numa bela passagem de Miséria da Filosofia (1847), em seu debate com Proudhon, encontra-se já outro exemplo da incorporação da noção de ideologia:

Os mesmos homens que estabelecem as relações sociais de acordo com a sua produtividade material produzem também os princípios, as idéias, as categorias, de acordo com as suas relações sociais. Por isso, essas idéias, essas categorias, são tão pouco eternas como as relações que exprimem. São produtos históricos e transitórios. ${ }^{27}$

Da mesma forma, ela reaparece no Manifesto do Partido Comunista (1848), já como fundamento da perspectiva comunista de crítica social:

Mas não discutais conosco aplicando à abolição da propriedade burguesa o critério de vossas noções burguesas de liberdade, cultura, direito etc. Vossas próprias idéias são produtos das relações de produção e de propriedade burguesas, assim como o vosso direito não passa da vontade de vossa classe erigida em lei, vontade cujo conteúdo é determinado pelas condições materiais de vossa existência como classe.

Essa concepção interesseira, que vos leva a transformar em leis eternas da natureza e da razão as relações sociais oriundas do vosso modo de produção e de propriedade - relações transitórias que surgem e desaparecem no curso da produção -, é por vós compartilhada com todas as classes dominantes já desaparecidas ${ }^{28}$.

[...] As acusações feitas aos comunistas em nome da religião, da filosofia e da ideologia em geral não merecem um exame aprofundado.

Será preciso grande inteligência para compreender que, ao mudarem as relações de vida dos homens, as suas relações sociais, a sua existência social, mudam também as suas representações, as suas concepções e conceitos; numa palavra, muda a sua consciência?

Que demonstra a história das idéias senão que a produção intelectual se transforma com a produção material? As idéias dominantes de uma época sempre foram as idéias da classe dominante.

Quando se fala de idéias que revolucionam uma sociedade inteira, isto quer dizer que no seio da velha sociedade se formaram os elementos de uma sociedade nova e que a dissolução das velhas idéias acompanha a dissolução das antigas condições de existência.

\footnotetext{
${ }^{27}$ Karl MARX, Miséria da Filosofia, p. 98.

${ }^{28}$ Karl MARX e Friedrich ENGELS, Manifesto Comunista, pp. 54/55.
} 
Quando o mundo antigo declinava, as antigas religiões foram vencidas pela religião cristã; quando, no século XVIII, as idéias cristãs cederam lugar às idéias Iluministas, a sociedade feudal travava sua batalha decisiva contra a burguesia então revolucionária. As idéias de liberdade religiosa e de consciência não fizeram mais que proclamar o império da livre concorrência no domínio do conhecimento.

"Mas" - dirão - "as idéias religiosas, morais, filosóficas, políticas, jurídicas etc. modificaram-se no curso do desenvolvimento histórico. A religião, a moral, a filosofia, a política, o direito sobreviveram sempre a essas transformações.

“Além disso, há verdades eternas, como a liberdade, a justiça etc., que são comuns a todos os regimes sociais. Mas o comunismo quer abolir estas verdades eternas, quer abolir a religião e a moral, em lugar de lhes dar uma nova forma, e isso contradiz todos os desenvolvimentos históricos anteriores".

A que se reduz essa acusação? A história de toda a sociedade até nossos dias moveu-se em antagonismos de classes, antagonismos que se têm revestido de formas diferentes nas diferentes épocas.

Mas qualquer que tenha sido a forma assumida, a exploração de uma parte da sociedade por outra é um fato comum a todos os séculos anteriores. Portanto, não é de espantar que a consciência social de todos os séculos, apesar de toda sua variedade e diversidade, se tenha movido sempre sob certas formas comuns, formas de consciência que só se dissolverão completamente com o desaparecimento total dos antagonismos de classes.

A revolução comunista é a ruptura mais radical com as relações tradicionais de propriedade; não admira, portanto, que no curso de seu desenvolvimento se rompa, do modo mais radical, com as idéias tradicionais ${ }^{29}$.

Em obras posteriores, igualmente, a incorporação da noção de inversão ideológica é recorrente. Por exemplo, em As lutas de classes na França (1850):

No seu programa eleitoral, o partido da ordem proclamava abertamente a dominação da classe burguesa, isto é, a manutenção das condições de vida da sua dominação, da propriedade, da família, da religião, da ordem! Apresentava a sua dominação de classe e as condições da sua dominação de classe naturalmente como a dominação da civilização e como as condições necessárias da produção material e das relações sociais de intercâmbio daí decorrentes ${ }^{30}$

Ou, ainda, em algumas das mais instigantes passagens de O Dezoito Brumário de Luís Bonaparte (1852), em que é incontestável a demonstração da relevância da crítica da ideologia para a compreensão da história e da política:

${ }^{29}$ Karl MARX e Friedrich ENGELS, Manifesto Comunista, pp. 56/57.

${ }^{30}$ As lutas de classes em França de 1848 a 1850, in MARX, ENGELS, Obras escolhidas, t. 1, p. 259. 
Os legitimistas e os orleanistas, como dissemos, formavam as duas grandes facções do partido da ordem. O que ligava estas facções aos seus pretendentes e as opunha uma à outra seriam apenas as flôres-de-lís e a bandeira tricolor, a Casa dos Bourbons e a Casa de Orléans, diferentes matizes do monarquismo? Sob os Bourbons governara a grande propriedade territorial, com seus padres e lacaios; sob os Orléans, a alta finança, a grande indústria, o alto comércio, ou seja, o capital, com seu séquito de advogados, professores e oradores melífluos. A monarquia legitimista foi apenas a expressão política do domínio hereditário dos senhores de terra, como a monarquia de julho fora apenas a expressão política do usurpado domínio dos burgueses arrivistas. O que separava as duas facções, portanto, não era nenhuma questão de princípios, eram suas condições materiais de existência, duas diferentes espécies de propriedade, era o velho contraste entre a cidade e o campo, a rivalidade entre o capital e o latifúndio. Que havia, ao mesmo tempo, velhas recordações, inimizades pessoais, temores e esperanças, preconceitos e ilusões, simpatias e antipatias, convicções, questões de fé e de princípio que as mantinham ligadas a uma ou a outra casa real quem o nega? Sobre as diferentes formas de propriedade, sobre as condições sociais, maneiras de pensar e concepções de vida distintas e peculiarmente constituídas. A classe inteira os cria e os forma sobre a base de suas condições materiais e das relações sociais correspondentes. O indivíduo isolado, que as adquire através da tradição e da educação, poderá imaginar que constituem os motivos reais e o ponto de partida de sua conduta. Embora orleanistas e legitimistas, embora cada facção se esforçasse por convencer-se e convencer os outros de que o que as separava era sua lealdade às duas casas reais, os atos provaram mais tarde que o que impedia a união de ambas era mais a divergência de seus interesses. E assim como na vida privada se diferencia o que um homem pensa e diz de si mesmo do que ele realmente é e faz, nas lutas históricas deve-se distinguir mais ainda as frases e as fantasias dos partidos de sua formação real e de seus interesses reais, o conceito que fazem de si do que são na realidade ${ }^{31}$.

É indispensável, na linha de citações feita aqui, recorrer ainda ao famoso prefácio da Contribuição à Crítica da Economia Política [1859], em que Marx expõe a relação entre base econômica e superestrutura da sociedade, quando se revela de modo mais abrangente como e em que medida se dá a determinação da consciência pelo ser social:

relações jurídicas, tal como formas de Estado, não podem ser compreendidas a partir de si mesmas nem a partir do chamado desenvolvimento geral do espírito humano, mas enraízam-se, isso sim, nas relações materiais da vida, cuja totalidade Hegel, na esteira dos ingleses e franceses do século XVIII, resume sob o nome de "sociedade civil", e de que a anatomia da sociedade civil se teria de procurar, porém, na economia política. A investigação desta última, que comecei em Paris, continuei em Bruxelas, para onde me mudara em consequência duma ordem de expulsão do Sr.

${ }^{31}$ Karl MARX, O 18 Brumário e Cartas a Kugelmann, pp. 51-52. 
Guizot. O resultado geral que se me ofereceu e, uma vez ganho, serviu de fio condutor aos meus estudos, pode ser formulado assim sucintamente: na produção social da sua vida os homens entram em determinadas relações, necessárias, independentes da sua vontade, relações de produção que correspondem a uma determinada etapa de desenvolvimento das suas forças produtivas materiais. A totalidade destas relações de produção forma a estrutura económica da sociedade, a base real sobre a qual se ergue uma superestrutura jurídica e política, e à qual correspondem determinadas formas da consciência social. O modo de produção da vida material é que condiciona o processo da vida social, política e espiritual. Não é a consciência dos homens que determina o seu ser, mas, inversamente, o seu ser social que determina a sua consciência. Numa certa etapa do seu desenvolvimento, as forças produtivas materiais da sociedade entram em contradição com as relações de produção existentes ou, o que é apenas uma expressão jurídica delas, com as relações de propriedade no seio das quais se tinham até aí movido. De formas de desenvolvimento das forças produtivas, estas relações transformam-se em grilhões das mesmas. Ocorre então uma época de revolução social. Com a transformação do fundamento económico revoluciona-se, mais devagar ou mais depressa, toda a imensa superstrutura. Na consideração de tais revolucionamentos tem de se distinguir sempre entre o revolucionamento material nas condições económicas da produção, o qual é constatável rigorosamente como nas ciências naturais, e as formas jurídicas, políticas, religiosas, artísticas ou filosóficas, em suma, ideológicas, em que os homens ganham consciência deste conflito e o resolvem. Do mesmo modo que não se julga o que um indivíduo é pelo que ele imagina de si próprio, tão-pouco se pode julgar uma tal época de revolucionamento a partir da sua consciência, mas se tem, isso sim, de explicar esta consciência a partir das contradições da vida material, do conflito existente entre forças produtivas e relações de produção sociais ${ }^{32}$.

Daí em diante ou, mais precisamente, em todo o período das obras de crítica da economia política, que envolve ainda Grundrisse, Teorias da mais-valia e $O$ capital, Marx não se dedica mais a "explicar" o que é ideologia ou, genericamente, as inversões entre consciência e realidade, mas não abandona, contudo, essa perspectiva de compreensão e crítica da realidade social $^{33}$. Basta ressaltar, neste sentido, a passagem de $O$ capital (1867) dedicada ao caráter fetichista da mercadoria, cuja tese central repousa justamente na inversão entre as características sociais dos objetos, que aparecem como se fossem simples características dos próprios objetos. Importante, ainda, ler o próprio Marx:

\footnotetext{
${ }^{32}$ Karl MARX, Para a crítica da economia política, pp. 530-531.

${ }^{33}$ No posfácio de 1873 à segunda edição do livro I d'O capital, aliás, está a célebre afirmação de Marx a respeito da inversão da dialética hegeliana: “A mistificação que a dialética sofre nas mãos de Hegel não impede, de modo algum, que ele tenha sido o primeiro a expor as suas formas gerais de movimento de maneira ampla e consciente. É necessário invertê-la, para descobrir o cerne racional dentro do invólucro místico" - Karl MARX, O capital [col. Os Economistas], vol. I, t. 1, p. 21.
} 
O misterioso da forma mercadoria consiste, portanto, simplesmente no fato de que ela reflete aos homens as características objetivas dos próprios produtos de trabalho, como propriedades naturais sociais dessas coisas e, por isso, também reflete a relação social dos produtores com o trabalho total como uma relação social existente fora deles, entre objetos. Por meio desse quiproqüo os produtos do trabalho se tornam mercadorias, coisas físicas metafísicas ou sociais. Assim, a impressão luminosa de uma coisa sobre o nervo ótico não se apresenta como uma excitação subjetiva do próprio nervo, mas como forma objetiva de uma coisa fora do olho. Mas, no ato de ver, a luz se projeta realmente a partir de uma coisa, o objeto externo, para outra, o olho. É uma relação física entre coisas físicas. Porém, a forma mercadoria e a relação de valor dos produtos de trabalho, na qual ele se representa, não têm que ver absolutamente nada com sua natureza física e com as relações materiais que daí se originam. Não é mais nada que determinada relação social entre os próprios homens que para eles aqui assume a forma fantasmagórica de uma relação entre coisas. Por isso, para encontrar uma analogia, temos de nos deslocar à região nebulosa do mundo da religião. Aqui, os produtos do cérebro humano parecem dotados de vida própria, figuras autônomas, que mantêm relações entre si e com os homens. Assim, no mundo das mercadorias, acontece com os produtos da mão humana. Isso eu chamo o fetichismo que adere aos produtos de trabalho, tão logo são produzidos como mercadorias, e que, por isso, é inseparável da produção de mercadorias.

Esse caráter fetichista do mundo das mercadorias provém, como a análise precedente já demonstrou, do caráter social peculiar do trabalho que produz mercadorias ${ }^{34}$

[...] O reflexo religioso do mundo real somente pode desaparecer quando as circunstâncias cotidianas, da vida prática, representarem para os homens relações transparentes e racionais entre si e com a natureza. A figura do processo social da vida, isto é, do processo da produção material, apenas se desprenderá do seu místico véu nebuloso quando, como produto de homens livremente socializados, ela ficar sob seu controle consciente e planejado. Para tanto, porém, se requer uma base material da sociedade ou uma série de condições materiais de existência, que, por sua vez, são o produto natural de uma evolução histórica longa e penosa ${ }^{35}$

O que se percebe, após percorrer as diversas obras de Marx (ou mesmo esta longa corrente de citações), é que o conceito de ideologia já aparece devidamente "descoberto" nas primeiras obras, contudo vai ganhando cada vez maior precisão ao passo em que Marx, ao avanço de suas pesquisas econômicas, descobre onde se radica a inversão que, até então, era flagrada nas relações sociais mais diversas, no discurso político, na filosofia, no direito etc., contudo não se tem com clareza o momento em que a inversão ocorre. Pode-se dizer, assim, que se trata de uma concepção que surge no interior de um debate filosófico e, ao ritmo em que se adensou a reflexão do autor rumo à superação das limitações que a filosofia apresentava, foi-se transformando em um agudo instrumento para a compreensão

\footnotetext{
${ }^{34}$ Karl MARX, O capital [col. Os Economistas], vol. I, t. 1, p. 71.

${ }^{35}$ Karl MARX, $O$ capital [col. Os Economistas], vol. I, t. 1, p. 76.
} 
da realidade. Aliás, isto não vale apenas para a ideologia: toda a reflexão de Marx parece se encaminhar da mesma forma, iniciando com uma crítica da filosofia, da política, do direito, que depois se encaminha para constituir uma crítica da totalidade materialmente fundamentada, desvendando seus nexos mais profundos e suas "leis".

Importante ainda notar que o conceito "final" de ideologia que pode ser apreendido da obra de Marx, radicado na relação fetichizada que se dá na produção social da existência, é de que ele estaria em desacordo com grande parte das explicações "unilaterais" (mecanicistas) que lhe foram atribuídas, como se a ideologia pudesse ser controlada completamente pela classe dominante e utilizada apenas no seu interesse. Que, sem dúvida, tal classe é a mais beneficiada, está claro, mas isto não dá conta da noção complexa que Marx se dedicou a desvendar e utilizar.

A inversão hegeliana entre ideias e realidade, que fez despertar a crítica marxista do idealismo filosófico que depois se converteria na crítica da forma de sociedade em que as relações entre os homens assumem a forma fantasmagórica de uma relação entre coisas, é o ponto inicial de uma trajetória sem rupturas, que se caracteriza muito mais por uma radicalização teórico-prática, feita por um jovem pensador disposto a romper com a filosofia que apenas "interpreta diferente" e não participa da necessária transformação social. Desde então, precisamente em 1843, aos 25 anos, Marx já sabia que "ser radical é agarrar as coisas pela raiz" e que, "para o homem, a raiz é o próprio homem". É no homem, então, entendido como ser social e flagrado na atividade que o define - a produção social da existência -, que a inversão fundamental da ideologia se desnudará.

Pode-se afirmar, então, que desde as inversões flagradas por suas primeiras obras como ideologia, depois como alienação (Entäusserung) e estranhamento (Entfremdung) ${ }^{36}$ já se elaborava a avançada compreensão do fetichismo que, para muito além do primeiro capítulo d'O capital, em que aparece como "fetichismo da mercadoria", é característica inseparável de todos os momentos do capital, de suas determinações mais simples às mais complexas. Esta é a lição de Jorge Grespan, identificando que, apenas ao enfrentar a inversão fetichista, "pela[a] qual as relações sociais aparecem aos agentes econômicos enquanto relação entre coisas e pel[a] qual a sociabilidade se transfigura em naturalidade" ${ }^{\natural 7}$, é que se torna possível o desvendamento do sistema do capital por Marx.

\footnotetext{
${ }^{36}$ Ver, aqui, István MÉSZÁROS, A teoria da alienação em Marx, e Jesus RANIERI, A câmara escura.

${ }^{37}$ Jorge GRESPAN, $O$ negativo do capital, p. 57. A obra, ademais, voltada ao estudo do conceito de crise encontrado na obra máxima de Marx, desdobra detalhadamente os diversos "níveis" de fetichismo do capital.
} 
Nota-se, então, que essa radicalização da ideologia como fetichismo desde as profundezas das relações sociais do capital (cruzando as dimensões de seu processo de produção, de sua circulação e de sua produção global) não significa o abandono das outras inversões ideológicas anteriormente flagradas por Marx, mas apenas a sua fundamentação mais precisa, como resultado da "dialética da sociabilidade capitalista"38.

\subsection{A ideologia depois de Marx}

Antes de adentrar, no próximo capítulo, na forma específica como o direito pode ser compreendido de acordo com a noção marxiana de ideologia, é relevante tratar, em poucas linhas, do amplo debate sobre a ideologia (entre marxistas e não marxistas).

A característica marcante deste debate ${ }^{39}$, segundo Leandro Konder, é que, sob o peso de um "determinismo econômico" atribuído até por marxistas a Marx, "a questão da ideologia [...] era esvaziada em sua significação. O conceito se empobrecia" ${ }^{\text {40 }}$. Na verdade, podemos dizer, a visão mecanicista - que não está em Marx, mas está em vários marxistas - facilitou imensamente a "compreensão" (entre aspas porque normalmente incorreta ou reducionista) do conceito de Marx e seu uso e abuso para todos os fins. Como ideologia era possível ver tudo. E nada, pois “a questão filosófica da ideologia cedia lugar a um campo de estudos bem mais restrito, que ficava entregue à competência exclusiva dos sociólogos, incumbidos de verificar a que grupos, classes ou setores da sociedade se ligavam as representações ideológicas" $"$.

Fácil compreender, portanto, diante dessa redução teórica, que toda uma extensa "tradição" de crítica da ideologia pretensamente marxista tenha se desenvolvido ao largo da própria concepção de Marx, esta sim radicada na crítica ao capital e em sua sociabilidade específica. É de se lamentar, mais ainda, porque se tornou absolutamente comum tomar por marxiana e por marxista toda e qualquer "crítica da ideologia" feita nos últimos 150 anos - da esquerda à direita, do cinema à canção popular -, alimentando um tipo perverso de indistinção teórica que minimiza o verdadeiro potencial crítico que

\footnotetext{
${ }^{38}$ Jorge GRESPAN, Marx, p. 44.

${ }^{39}$ Para conferir a variedade de teorias sobre ideologia, remeto às obras de Terry EAGLETON, Ideologia; Leandro KONDER, A questão da ideologia; e Slavoj ZIZEK, Um mapa da ideologia. Refiro, ainda, Alfredo BOSI, Ideologia e contraideologia, estudo recente sobre o tema, dando conta das diversas correntes teóricas. Para nosso interesse aqui, entre os diversos problemas competentemente abrangidos pelo autor, ver o capítulo "Liberalismo e Estado-Providência - confrontos e compromissos", pp. 372/393.

${ }^{40}$ Leandro KONDER, A questão da ideologia, p. 55.

${ }^{41}$ Leandro KONDER, A questão da ideologia, p. 55.
} 
conceitos como ideologia, alienação, estranhamento e fetichismo assumiram nas obras de Marx, tanto para seu desenvolvimento teórico quanto político.

Obviamente, a "redescoberta filosófica" de Marx nos anos 1920, por pensadores como Lukács e Korsch, teve imensos méritos ao influenciar o desenvolvimento teórico da questão da ideologia e seu espraiamento para os mais diversos recantos (psicanálise, estética, teoria da linguagem etc. ${ }^{42}$ ) até nossos dias, contudo, muito desse desenvolvimento e espraiamento posterior tem sido marcado pelo abandono da concepção profundamente dialética e materialista que era fundamental para Marx, radicada na produção do capital. Pode-se dizer, assim, que Marx começa onde grande parte da crítica da ideologia escrita depois dele termina, ou ainda, aquelas inversões que despertaram na década de 1840 a crítica de Marx, que incansavelmente mergulhou no modo de produção capitalista até descobrir tanto a sua "inversão fetichista" mais radical quanto as diversas formas que ela pode assumir, passam a ser a preocupação exclusiva dos críticos, não o seu ponto de partida em direção às raízes da mistificação. Para usar uma metáfora problemática ${ }^{43}$, é como se os filósofos tivessem partido da "base econômica" em direção à "superestrutura ideológica" e, nesta, tivessem encontrado todo o necessário para sua teoria. Se este não é o reducionismo mecanicista dos primeiros marxistas, não deixa de ser igualmente facilitador e de negar a feição dialética do conceito de fetichismo desenvolvido por Marx.

Retomar, portanto, a crítica da ideologia a partir de Marx, como aqui se pretende, não é questão de preciosismo filológico, mas é a oportunidade sempre renovada de dar novo ataque crítico e emancipatório em um combate que justificou que Marx tenha escrito tantas e tantas páginas para desvendar seus mecanismos e fetiches.

\footnotetext{
${ }^{42}$ Ver os capítulos especificamente dedicados a cada tema em Leandro KONDER, A questão da ideologia. ${ }^{43}$ Abrindo um capítulo esclarecedor sobre o tema, Ellen M. WOOD afirma: "A metáfora base/superestrutura sempre gerou mais problemas do que soluções" - Democracia contra capitalismo, p. 51.
} 


\section{PARA UMA TEORIA DA IDEOLOGIA JURÍDICA}

\subsection{O debate sobre direito e ideologia}

Se se pode afirmar, com segurança, que a crítica à função ideológica do direito já tem grande desenvolvimento na obra de Marx, ao revelar a profunda relação entre os pilares do direito moderno (propriedade privada, contrato, sujeito de direito etc. ) e as necessidades próprias da afirmação e reprodução do capitalismo, apontando já com certo detalhe o papel mistificador que as categorias jurídicas exercem, é no século XX, todavia, que serão escritas as páginas mais detidas à crítica do direito.

Ocuparam-se do debate diversos autores, espalhados pelo mundo, passando a ser apresentados, aqui e ali, como uma corrente crítica do direito ${ }^{44}$, nem toda ela de orientação marxista, por certo, mas voltada principalmente a acusar, na produção e na aplicação da normas jurídicas, o seu conteúdo de classe. Outros autores, poucos, dedicaram-se a trilhar os caminhos da crítica do direito com o instrumental do materialismo histórico.

O exemplo maior, entre estes, é E. B. Pachukanis ${ }^{45}$ (1891-1937), o mais importante jurista marxista, que se dedicou justamente a realizar, com base na crítica da economia política realizada por Marx, a crítica detalhada do positivismo jurídico, tendo debatido frontalmente tanto com o positivismo jurídico mais estrito, na pessoa de seu principal expoente, Hans Kelsen (1881-1973), quanto com um autor mais "progressista" da teoria jurídica, Karl Renner (1870-1950). Se na polarização com Kelsen, numa oposição muito aberta entre dois modelos teóricos, a crítica de Pachukanis revela aspectos nucleares da vinculação entre direito e capitalismo, é no debate com as teses progressistas de Renner (politicamente à esquerda, também) que Pachukanis esforça-se ainda mais em mostrar

\footnotetext{
${ }^{44}$ Competente relato dos autores e ideias compreendidas como parte das "escolas críticas" da teoria jurídica está em António Manuel HESPANHA, Panorama histórico da cultura jurídica européia, pp. 218/235.

${ }^{45}$ Um detalhe: a grafia do nome do jurista soviético varia entre Pasukanis, Pashukanis e Pachukanis; a sua principal obra editada no Brasil traz seu nome ora com um simples "s" (na edição da Renovar, 1989), ora com "ch" (na edição da Acadêmica, 1988); outros trabalhos, em razão da adoção - voluntária ou não - da forma inglesa, apresentam-no com "sh". Contudo, adotarei aqui, na minha redação, a forma utilizada pelo seu principal leitor brasileiro, Marcio Bilharinho Naves, em Direito e Marxismo - Pachukanis.
} 
como esta vinculação é incontornável, afirmando com veemência a ineficácia de qualquer tentativa de reformar ou conter juridicamente o sistema capitalista ${ }^{46}$.

O debate sobre a ideologia ${ }^{47}$, inevitavelmente, ocupa lugar de destaque na crítica do direito desde então, principalmente porque desde as primeiras décadas do século XX, especialmente ao redor da Constituição de Weimar, não se trata mais apenas de debater com as perspectivas liberais mais convencionais da teoria jurídica, mas sim com a crescente defesa do papel que o direito pode exercer na transformação social.

Aqui, em especial, é esta a questão que se põe: o debate sobre direito e ideologia mais importante de nossa época não é tanto a crítica das perspectivas conservadoras nem mesmo uma contenda interna à já citada corrente crítica, com toda a sua heterogeneidade. É, antes de tudo, um debate relevante para a crítica marxista do direito (seja ela feita por juristas ou por pesquisadores de outras áreas), em cujos limites tem-se consolidado cada vez mais uma posição de recusa a qualquer potencial transformador ao direito. Esta posição, quase unânime na crítica marxista, é direta: ao constatar a especificidade histórica do direito burguês (que aqui não é negada), julga irrelevantes quaisquer esforços jurídicos ou políticos de aproveitamento do direito (e do Estado) para as lutas sociais.

Neste sentido, Mauro Iasi afirma que o caráter social assumido pela legislação resulta em "panacéias distributivistas" e que lutar por dentro do direito "Não é uma maneira de se chegar ao socialismo, mas um meio de evitá-lo"48. É necessário citar:

\begin{abstract}
A ação da classe é moldada para a conformidade; a identidade de trabalhadores é substituída por uma de cidadão ou povo; a ação eleitoral, como via principal e, por vezes, única, desorganiza a classe como classe e a prepara para o consentimento. As ideias proletárias vão se enfraquecendo em um eco empobrecido da Revolução Francesa. Aos trabalhadores, como uma parte a mais da sociedade capitalista, como parte integrante do capital, como capital variável, resta exigir seus "direitos" e cumprir seus "deveres". O horizonte de "direitos" é delimitado pela ordem: receber salário pela venda de sua força de trabalho, ter acesso e consumir as mercadorias necessárias à reprodução dessa força de trabalho, morar, vestir-se, comer. Às vezes, podem até mesmo ousar pensar no futuro desde que não ultrapassem a ordem das mercadorias e do capital, e com a condição de que seu sonho poderá ser dividido em prestações de um crediário. ${ }^{49}$
\end{abstract}

\footnotetext{
${ }^{46}$ Obra recente sobre a teoria política em Marx dedica diversas páginas ao direito, em especial a demonstrar os avanços da perspectiva pachukaniana, ainda que sejam frágeis as críticas formuladas ao autor tomando por base as obras de juventude de Marx. Ver Thamy POGREBINSCHI, O enigma do político, pp. 291/331.

${ }^{47}$ Remeto, aqui, à reflexão que desenvolvi sobre o tema em Tarso de MELO, Direito e ideologia, 32/39.

${ }^{48}$ Mauro Luis IASI, Ensaios sobre consciência e emancipação, p. 85.

${ }^{49}$ Mauro Luis IASI, Ensaios sobre consciência e emancipação, p. 86. No mesmo sentido, Marcio Bilharinho NAVES: “A conseqüência política de todo esse processo [legalização da greve etc.] consiste na neutralização
} 
Estas palavras, sem dúvida, rondam a investigação aqui realizada, mas convivem com dúvidas suscitadas pela observação da realidade e pela leitura de autores igualmente admiráveis, ou até mesmo das obras em que esta crítica tem sido feita.

A perspectiva aqui apresentada é de que a constatação da natureza capitalista do direito não pode significar a desconsideração de seu potencial político, mais do que propriamente jurídico. De acordo com os conceitos de ideologia e fetichismo apresentados por Marx, como demonstrarei, uma teoria da ideologia jurídica deve ter em seu foco a necessária ambiguidade política das instituições e ordenamentos, como uma característica que, ao ser essencial para a formação de um melhor lastro ideológico do capital na sociedade, também custa, por outro lado, a manutenção da pressão por transformação social no espectro político. Em suma, o direito, no mesmo momento em que empreende sua função de dominação, não pode evitar que, na "mão contrária", realize também certa abertura e certo estímulo à resistência dos próprios grupos dominados.

É neste ponto que se pode identificar o caráter dialético da ideologia jurídica, demonstrando que a função exercida pelo direito no conjunto da ideologia social é marcada por uma inescapável "mão dupla" (com o perdão das metáforas automobilísticas...), que redunda numa forma de dominação sob a qual diversos grupos sociais e profissionais da área jurídica, mesmo convencidos da insuficiência dos meios de que dispõem, encontram suas razões para insistir no direito como forma de luta política.

Mesmo nos autores que negam em bloco o potencial político do direito, aqui e ali aparecem indicações de que um "uso tático" do direito não deve ser desprezado. Desde $\operatorname{Marx}^{50}$, pelo menos, toda crítica demolidora do direito convive com um aceno para um tal

da luta de classe operária. Quando o Estado só admite a política concentrada 'de direito' na sua esfera de competência, toda luta que ultrapasse os marcos da reivindicação profissional, e consista em uma ameaça ao processo de valorização do capital, é interditada e considerada ilegal. Assim, a greve ou a ocupação de fábrica que desorganize a produção torna-se uma greve 'política', porque questiona o poder de classe da burguesia, a sua dominação sobre os trabalhadores. Ora, a política, nós já o sabemos, é a esfera exclusiva de manifestação dos cidadãos no Estado por meio de eleições; no âmbito da sociedade civil - onde se situa a fábrica - só se admitem as manifestações de natureza privada, as reivindicações profissionais. Portanto, se os trabalhadores quiserem se manifestar politicamente, deverão se despojar de sua condição de classe e participar do processo político como cidadãos.

A crítica da democracia, a partir dos desenvolvimentos de $O$ capital, permite revelar a sua natureza irremediavelmente burguesa e a sua função como elemento que encerra a luta de classe operária nos marcos da legalidade e da institucionalidade burguesas" - Marx: ciência e revolução, p. 78.

${ }^{50}$ Refiro-me à célebre passagem final de Salário, Preço e Lucro (1865): "Estas breves indicações serão suficientes para mostrar que o próprio desenvolvimento da indústria moderna tem progressivamente de fazer pender a balança a favor do capitalista contra o operário e que, consequentemente, a tendência geral da produção capitalista não é para elevar mas para afundar o nível médio dos salários ou de empurrar o valor do trabalho mais ou menos para o seu limite mínimo. Sendo esta a tendência das coisas neste sistema, quererá 
"uso tático",51, que deve ser feito pelos trabalhadores apenas enquanto uma situação revolucionária não se apresentar e sempre em associação com uma perspectiva de luta menos imediatista que a jurídica. Os críticos marxistas, no geral, dando este ou outro nome, reconhecem uma ambiguidade no direito, mas contentam-se em desvendá-la na teoria e abandonam o debate sobre suas possibilidades táticas de enfrentamento político. Meu objetivo, a seguir, é investigar justamente tais possibilidades.

Deve-se considerar que a perspectiva aqui prestigiada não é, de maneira alguma, incompatível com uma crítica radical do direito, mas apenas abre uma fronteira tantas vezes indicada e tão poucas vezes investigada, a do uso tático - ou estratégico - do direito nas lutas sociais. Ademais, diante de uma realidade tão adversa, é provável que a teoria crítica que menospreza ou simplesmente abandona o direito (assim como o Estado, a democracia burguesa etc.) como campo de lutas sociais esteja correta.

isto dizer que a classe operária deverá renunciar à sua resistência contra as investidas do capital e abandonar as suas tentativas de tirar o melhor proveito das oportunidades ocasionais para a sua melhoria temporária? Se o fizesse seria degradada a uma massa nivelada de miseráveis domesticados sem salvação. Penso ter mostrado que as suas lutas pelo nível de salários são incidentes inseparáveis de todo o sistema de salários, que em 99 casos em 100 os seus esforços por elevar os salários são apenas esforços para manter o valor dado do trabalho e que a necessidade de debater o seu preço com o capitalista é inerente à sua condição de terem de se vender eles próprios como mercadorias. Cedendo cobardemente no seu conflito de todos os dias com o capital, certamente que se desclassificariam para o empreendimento de qualquer movimento mais amplo.

Ao mesmo tempo, e completamente à parte da servidão geral envolvida no sistema de salários, a classe operária não deverá exagerar para si própria a eficácia última [the ultimate working] destas lutas de todos os dias. Não deverá esquecer que está a lutar com os efeitos, mas não com as causas desses efeitos; que está a retardar o movimento descendente, mas não a mudar a sua direcção; que está a aplicar paliativos, mas não a curar a doença. Por conseguinte, não deverá estar exclusivamente absorvida nestas inevitáveis lutas de guerrilhas que incessantemente derivam das investidas sem fim da capital ou das mudanças do mercado. Deverá compreender que, [juntamente] com todas as misérias que lhe impõe, o sistema presente engendra simultaneamente as condições materiais e as formas sociais necessárias para uma reconstrução económica da sociedade. Em vez do motto conservador "Um salário justo para um trabalho diário justo!”, deverá inscrever na sua bandeira a palavra de ordem revolucionária: "Abolição do sistema de salários!".

Depois desta exposição muito longa e temo que maçadora, em que fui obrigado a entrar para fazer algum jus ao assunto, concluirei propondo as seguintes resoluções:

Em primeiro lugar. Uma subida geral na taxa dos salários resultaria numa queda da taxa geral do lucro, mas, em termos gerais, não afectaria os preços das mercadorias.

Em segundo lugar. A tendência geral da produção capitalista não é para elevar, mas para afundar o nível médio dos salários.

Em terceiro lugar. Os Sindicatos [Trade Unions] funcionam bem como centros de resistência contra as investidas do capital. Fracassam parcialmente por um uso não judicioso do seu poder. Fracassam geralmente por se limitarem a uma guerra de guerrilha contra os efeitos do sistema existente, em vez de simultaneamente o tentarem mudar, em vez de usarem as suas forças organizadas como uma alavanca para a emancipação final da classe operária, isto é, para a abolição última do sistema de salários" - MARX, ENGELS, Obras escolhidas, t. 2, pp. 77/78.

51 Marcio Bilharinho NAVES, tratando do pensamento sobre democracia em As lutas de classes na França e $O$ Dezoito Brumário, obras em que, segundo Naves, Marx ainda não havia estabelecido "a relação entre a democracia e a circulação mercantil-capitalista", comenta que "a democracia adquire caráter peculiar, enquanto forma política específica do Estado burguês, e, portanto, uma forma que não pode ser utilizada pela classe operária - a não ser de modo limitado, taticamente - no curso da luta contra a dominação burguesa, assim como no período da transição socialista" - Marx: ciência e revolução, p. 76 (grifos nossos). 
Contudo, como falar em "ambiguidade" do direito não significa consequentemente acreditar em sua pretensa "neutralidade" 52 , faz-se necessário investigar os efeitos reais de sua ambiguidade ${ }^{53}$, com a convicção de que "a democracia"54 - nas palavras de Márcio Bilharinho Naves quanto às ideias de Marx sobre a democracia republicana - "interessa aos trabalhadores na medida exata em que propicia o enfrentamento mais aberto entre as classes, favorecendo a maturação da classe operária e introduzindo no interior da classe dominante um elemento de inquietação e de instabilidade" ${ }^{, 55}$.

Se insistir no direito como campo de lutas servir ao menos para deixar mais claros os antagonismos sociais, já será um ganho. A aparente harmonia social sob a igualdade jurídica só interessa a quem não está do lado fraco da desigualdade real.

\subsection{Ambiguidade do direito: abertura e estímulo à resistência}

Como diz Mészáros, "um dos aspectos mais desalentadores do fetichismo jurídico é que ele cria a ilusão de que sua importância é extremamente grande - e é precisamente deste modo que desempenha suas funções na sociedade capitalista -, desviando a atenção do verdadeiro alvo"56. Falar, portanto, em lutar por direitos - reivindicando novos, defendendo antigos ou buscando realizar uns e outros - pode sempre significar ser vítima da ilusão, mas exclui fatalmente a possibilidade de romper com o fetichismo?

Antes de responder, é necessário dedicar um maior detalhamento ao que se vem tratando aqui como ambiguidade do direito. Ao afirmar que o direito é ambíguo na forma como exerce a sua função na dominação social, tanto impondo a conservação de um tipo

\footnotetext{
52 "Com essa análise a respeito da ambigüidade dos interesses das classes inconciliáveis não pretendemos caracterizar nenhuma neutralidade das suas instituições expressivas, tais como o Estado, o Direito, o movimento sindical, etc., visto que a existência mesma das classes pressupõe, como já dito, a dominância da assimetria e, também, da oposição e de conflito" - Alaôr Caffé ALVES, Estado e Ideologia, p. 162.

53 "A constatação da natureza ideológica de um conceito não nos dispensa, de forma alguma, da obrigação de estudar a realidade objetiva, quer dizer, a realidade existente no mundo exterior e não apenas na consciência" - E. B. PASUKANIS, A teoria geral do direito e o marxismo, p. 43. Ou ainda: "O Estado não é apenas uma forma ideológica, mas também, e simultaneamente, uma forma de ser social. A natureza ideológica de um conceito não suprime a realidade e a materialidade das relações das quais ele é expressão" - idem, p. 44.

${ }^{54}$ Serão utilizadas, durante a tese, muitas reflexões que, se foram inicialmente apontadas para o direito ou para o Estado ou para as instituições democráticas, são válidas, no geral, para todos eles, tendo em vista a profunda implicação entre esses elementos, tanto do ponto de vista da realidade, quanto da teoria.

${ }^{55}$ Marcio Bilharinho NAVES, Marx: ciência e revolução, p. 75. Na sequência, tratando do "caráter tático que a democracia tem para Marx", Naves afirma "os trabalhadores devem, diz Marx, esgotar todas as possibilidades de utilização da democracia ao mesmo tempo em que a ultrapassam, com o recurso direto a medidas e iniciativas ilegais, com o emprego da violência revolucionária", idem.

${ }^{56}$ István MÉSZÁROS, O poder da ideologia, p. 506.
} 
específico de relações sociais quanto prevendo relações diferentes daquelas, ecoam aqui as precisas palavras de Alaôr Caffé Alves em sua análise do Estado:

O caráter ambíguo que os interesses de classe muitas vezes tomam reflete a contradição interna na unidade do sistema de classes, especialmente no modo de produção capitalista. Com efeito, se os interesses de classe fossem apenas repulsivos entre si, não havendo nenhuma conexão ou parcial identidade entre eles, o sistema econômico não sobreviveria para além de um momento, não sendo possível sua reprodução por largos períodos históricos. Nessa ambigüidade apontada, porém, entreabre-se uma certa linha funcional que permite ao sistema dominante pôr em maior destaque o caráter "cooperativo" das classes sociais, como se elas fossem entre si puramente complementares. Neste jogo ideológico, o conflito e as contradições são tidos como episódicos, insuflados "de fora", revelando uma certa anomia ou mesmo "patologia" do processo social. Esse fato enseja, portanto, considerar que o processo dialético do relacionamento entre as classes, implicando uma unidade de contrários, propicia pôr em relevo também, pelas forças dominantes e conservadoras do status quo, o aspecto parcial da possível compatibilização aparente - sempre transitória - dos interesses de classes opostas, com a conseqüente depressão ou ocultação, nas abordagens prático-teóricas desse tema, de seus antagonismos. ${ }^{57}$

A ambiguidade do direito, assim, resulta da necessidade de que os interesses sociais antagônicos apareçam de forma complementar nas instituições políticas e jurídicas por meio das quais a assimetria entre as classes tem sua reprodução garantida. É como uma forma aparentemente neutra e equidistante de composição dos interesses sociais em conflito que o Estado, expressando-se na forma do direito, assume a tarefa de equilibrar relações que, em última análise, não podem ser equilibradas. No entanto, se é fácil demonstrar que tal neutralidade é falsa, interessa perceber que sua aparência tem por consequência uma força real, pois, no plano político e jurídico, cria permanentemente espaço para o incômodo das reivindicações corretamente formuladas e, no plano da consciência social, em razão da distância que se apresente entre norma e realidade e dos obstáculos que se revelem diante das tentativas formais de aproximação entre elas, serve à contestação ideológica do sistema, de suas instituições ou de seus agentes:

[...] é preciso também assinalar que, mesmo na presença do Estado, se a disparidade de forças entre as classes sociais em conflito for além de um certo nível, pode acarretar, pelo seu desenrolar espontâneo, a destruição de todo aquele sistema de relações sociais. Nesse sentido, o poder estatal interferente, ao assegurar a condição de existência ou de sobrevivência da classe menos favorecida,

${ }^{57}$ Alaôr Caffé ALVES, Estado e ideologia, p. 156. 
está, em certo sentido e de modo perverso, protegendo ao mais forte precisamente contra as funestas consequiências de sua própria força. Isso ocorre, por exemplo, com a legislação de proteção ao trabalhador assalariado nos Estados capitalistas, a qual exprime a ambigüidade daquele processo, pois também é a condição para limitar e resguardar os capitalistas dos exageros de sua própria força econômica, comprometedores das relações sociais que os constituem como classe orgânica e vitalmente vinculada à dos trabalhadores. ${ }^{58}$

É sobre essa perversão que o direito se sustenta como o mais hábil instrumento de dominação encontrado pela sociedade capitalista, capaz de manter sob controle, em grande medida, uma massa que seria impossível conter pelo simples recurso à força. No caso específico dos direitos sociais, objeto principal deste estudo, a ambiguidade é ainda mais radical, pois este é o conjunto normativo que, na sua eficiente proteção à reprodução do capital, deixa em primeiro plano tanto a oposição aos interesses da classe dominante quanto a proteção da classe dominada, estes que, na verdade, são objetivos (ou resultados) secundários, mas aparecem como sendo a sua verdadeira destinação. Entretanto, o poder de mistificação do direito é tão grande que nem ele próprio é capaz de limitar, de modo que, contrariamente ao que poderia pretender uma visão de "mão única" desse processo de dominação, como uma força unilateralmente exercida, o discurso da transformação social vendido na forma normativa - acaba sendo (re)incorporado ao acervo político e ideológico dos grupos interessados e, no limite, estimula movimentos organizados e efetivos de reivindicação social, como no caso dos trabalhadores rurais sem-terra ${ }^{59}$.

Pode-se defender, assim, que a combatividade dos trabalhadores, ora sob maior organização, ora de modo espontâneo e esparso (atualmente até mesmo individualizado na forma de demandas judiciais), resulta em parte significativa da expressão que as lutas de classes passadas e presentes assumem no direito. Se este é um processo mais ou menos consciente ${ }^{60}$ em determinadas situações históricas, não se altera o fato de que a ideologia

\footnotetext{
${ }^{58}$ Alaôr Caffé ALVES, Estado e ideologia, p. 278.

${ }^{59}$ Estudei detidamente este exemplo em Tarso de MELO, Direito e ideologia, 2009.

60 "a consciência de classe, como auto-conhecimento dos agentes sociais a respeito de sua posição diferenciada e objetiva frente aos meios de produção e da conseqüente consciência relativa à apropriação privada do excedente econômico produzido socialmente, só se torna possível no âmbito e processo das relações antagônicas, dos conflitos políticos e ideológicos decorrentes exatamente da disparidade e desigualdade das situações de classe. Isso quer dizer, em última instância, que, enquanto a consciência da classe dominante consiste em sobrelevar hegemonicamente o fator recessivo dos interesses comuns da sociedade, tentando identificar com eles os próprios interesses para ilidir as contradições inerentes ao sistema de classes, a consciência da classe subalterna, em seu movimento crítico-reflexivo, consiste em desnudar essas contradições reveladoras da divisão social e da exploração econômica dela resultante, com vistas a superar tal situação com o predomínio de seus interesses (nas lutas econômicas) ou com a supressão dos fatores estruturais da desigualdade (nas lutas políticas)" - Alaôr Caffé ALVES, Estado e ideologia, p. 162.
} 
jurídica, a fetichização das demandas sociais como direitos, repercute sobre as classes sociais de modo ambíguo: não pode abrir mão de proteger o desequilíbrio de classes sobre o qual se sustenta, mas está condenada a compatibilizá-las formalmente por meio de medidas minimamente efetivas, das quais costuma resultar sua contestação.

Um dos principais exemplos que podemos colher na história das lutas sociais sobre o resultado dessa ambiguidade está na excepcional obra de Friedrich Engels sobre a classe trabalhadora inglesa. Nela, Engels destaca que a lei de 1824 que garantiu aos trabalhadores a "liberdade de associação", antes conferida apenas à aristocracia e à burguesia, ao retirar os trabalhadores da clandestinidade, além de ser determinante para as conquistas pontuais, contribuiu de modo decisivo para o aumento das reivindicações ${ }^{61}$. Leia-se:

Quando, em 1824, os operários obtiveram o direito à livre associação, essas sociedades rapidamente se expandiram por toda a Inglaterra e tornaram-se fortes. Em todos os ramos de trabalho constituíram-se organizações semelhantes (trade unions), com o objetivo declarado de proteger o operário contra a tirania e o descaso da burguesia. Eram suas finalidades fixar o salário, negociar en masse, como força, com os patrões, regular os salários em relação aos lucros patronais, aumentá-los no momento propício e mantê-los em todas as partes no mesmo nível para cada ramo de trabalho; por isso, trataram de negociar com os capitalistas uma escala salarial a ser cumprida por todos e recusar empregos oferecidos por aqueles que não a respeitassem. Ademais, outras finalidades eram: manter o nível de procura do trabalho, limitando o emprego de aprendizes e, assim, impedir também a redução dos salários; combater, no limite do possível, os estratagemas patronais utilizados para reduzir salários mediante a utilização de novas máquinas e instrumentos de trabalho etc.; e, enfim, ajudar financeiramente os operários desempregados. Essa ajuda se efetua diretamente, com os fundos de caixa da associação, ou mediante um cartão de identificação, em que constam os dados do titular, que vai de localidade em localidade procurando trabalho e, em cada uma delas, apresentandose aos seus companheiros, recebe deles indicações e apoio para conseguir emprego - os trabalhadores chamam esse movimento migratório de tramp e, por isso, quem o faz é um tramper. Para colimar seus fins, a associação elege um presidente e um secretário, que recebem um estipêndio - porque é óbvio que não se pode esperar que os patrões dêem emprego a esse tipo de operários -, e um comitê, que é responsável pelo recolhimento semanal das cotas e pelo bom uso do fundo com elas constituído. Quando foi possível e vantajoso, os operários de um mesmo ramo de trabalho de diferentes distritos uniram-se numa associação federada, organizando assembléias de delegados em datas fixas. Em alguns casos, tentou-se unir numa só organização de toda a Inglaterra os operários de um mesmo ramo e também houve tentativas - a primeira, em 1830 - de criar uma única associação geral de operários de todo o reino, com organizações específicas para cada categoria; mas

${ }^{61}$ Friedrich ENGELS, A situação da classe trabalhadora na Inglaterra, p. 249. 
esses experimentos foram raros e de curta duração, porque uma organização desse tipo só pode ter vida e eficácia à base de uma agitação geral de excepcional intensidade. ${ }^{62}$

A obra clássica revela, em toda parte, empolgação pessoal de Engels com as possibilidades revolucionárias dos operários ingleses e, em igual medida, também um discurso de estímulo a lutas mais amplas, muito consciente de que, com a força das associações e das greves, a classe operária "se insurge contra a burguesia e ataca, em primeiro lugar, seu poder político, a muralha legal com que ela se protege"63.

Segundo Engels, “A história dessas associações é a história de uma longa série de derrotas dos trabalhadores, interrompida por algumas vitórias esporádicas" ${ }^{\text {, }}$, mas reconhece que a oposição dos operários, coletivamente, interfere na forma como a concorrência entre os industriais afetaria diretamente os salários. E diz mais:

sua omissão equivaleria à aceitação dessas condições de vida, ao reconhecimento do direito de a burguesia explorá-los durante os períodos de prosperidade e deixá-los morrer de fome nos períodos desfavoráveis. Os operários protestam porque ainda não perderam os sentimentos humanos - e protestam desse modo porque são ingleses, pessoas práticas, que expressam na ação o seu protesto; não são teóricos alemães, que, devidamente protocolado e posto ad acta seu protesto, vão para casa dormir o sono tranqüilo dos contestatários. Ao contrário, o protesto concreto dos ingleses tem sua eficácia: mantém em certos limites a avidez da burguesia e estimula a oposição dos operários contra a onipotência social e política da classe proprietária, ao mesmo tempo em que leva os trabalhadores a compreender que, para destruir o poder da burguesia, é preciso algo mais que associações operárias e greves. $^{65}$

Fica claro, assim, que, para Engels, a principal conquista das lutas cotidianas dos trabalhadores por melhores condições de trabalho está para além dos resultados imediatos. Tem a ver principalmente com a aquisição de um nível de consciência de classe que, sem a luta cotidiana, seria inacessível, mas que a ela não se restringe.

É significativo, sem dúvida, que no prefácio escrito à edição alemã de seu livro em 1892, Engels tenha mostrado que grande parte da sua empolgação com a combatividade dos trabalhadores ingleses não se justificou, ou ao menos não serviram os instrumentos (associações, greves, direitos) em que tal combatividade foi aplicada, tendo em vista que o

\footnotetext{
${ }^{62}$ Friedrich ENGELS, A situação da classe trabalhadora na Inglaterra, p. 250.

${ }^{63}$ Friedrich ENGELS, A situação da classe trabalhadora na Inglaterra, p. 262.

${ }^{64}$ Friedrich ENGELS, A situação da classe trabalhadora na Inglaterra, p. 251.

${ }^{65}$ Friedrich ENGELS, A situação da classe trabalhadora na Inglaterra, pp. 252/253.
} 
sucesso daquelas reivindicações esgotou-se nas conquistas imediatas e teve efeito negativo sobre a politização dos operários, formando-se uma "aristocracia operária", beneficiada pelos bons momentos da indústria inglesa e, assim, contaminada pelos "preconceitos burgueses”. Mas Engels não esmoreceu, pois via então novas gerações, mais vivas, que, apesar de repetirem erros, conquistavam resultados eleitorais importantes:

Tal conquista despertou entre os operários uma alegria indescritível. Pela primeira vez, viram e sentiram a magnitude de sua força na utilização do direito do voto no interesse de sua classe. Rompeu-se a fé supersticiosa no "grande partido liberal" que, por quarenta anos, predominou entre os operários ingleses. Estes se convenceram, à base de exemplos tangíveis, que eles, os operários, constituem a força decisiva na Inglaterra, desde que o queiram e saibam o que querem. As eleições de 1892 marcam o surgimento dessa vontade e dessa consciência. ${ }^{66}$

Evidentemente, Engels percebe nessas lutas dos trabalhadores a implicação entre dois fatores: há conquistas materiais imediatas e há avanços de consciência significativos sem a luta por aqueles, estes não surgiriam; sem estes, aqueles são insignificantes. Em outras palavras: deve-se buscar, por meio da organização política, que as conquistas materiais dos trabalhadores não se esgotem em si próprias, transcendam os limites mais restritos da relação assalariada em direção ao fim do trabalho assalariado.

Desde então, está claro para Engels que tal desafio diz respeito tanto às lutas econômicas dos trabalhadores quanto às suas lutas propriamente políticas, que devem ser integradas, como uma forma de suportar, de modo mais duradouro e amplamente coletivo, o enfrentamento da classe burguesa, digamos, em seus terrenos.

É Marx, já nas páginas de sua principal obra, que vai afirmar que "Nada caracterizaria melhor o espírito do capital que a história da legislação fabril inglesa de 1833 até 1864 !"67, o que justifica que dedique ao assunto grande parte do primeiro livro de $O$ capital. Para seguir os instrumentos jurídicos em que resultaram os conflitos da época e, mais que isso, ver como neles se incorpora o movimento de reprodução do capital com sua

\footnotetext{
${ }^{66}$ Friedrich ENGELS, A situação da classe trabalhadora na Inglaterra, p. 358. Citado prefácio, aliás, é da mesma época em que Engels escreve uma nova introdução (em 1985) ao livro de Marx, As lutas de classes em França de 1848 a 1850 (de 1850), afirmando: "os operários alemães tinham prestado um segundo grande serviço à sua causa, além do primeiro que residia na sua simples existência como Partido Socialista, o partido mais forte, mais disciplinado e que mais rapidamente crescia. Tinham fornecido aos seus camaradas de todos os países uma nova arma, uma das mais cortantes, mostrando-lhes como se utiliza o sufrágio universal" - in MARX, ENGELS, Obras escolhidas, t. 1, pp. 198/199. E ainda: "Para utilizar as palavras do programa marxista francês, transformaram o direito de voto, de moyen de duperie qu'il a été jusquici, en instrument d'émancipation - de um meio de logro que tinha sido até aqui, em instrumento de emancipação" - p. 199.

${ }^{67}$ Karl MARX, O capital [col. Os Economistas], vol. I, t. 1, p. 221.
} 
inerente contraditoriedade, Marx parte da convicção de que "Aprés moi le deluge! é a divisa de todo capitalista e toda nação capitalista. $O$ capital não tem, por isso, a menor consideração pela saúde e duração de vida do trabalhador, a não ser quando é coagido pela sociedade a ter consideração"68. Se "salários razoáveis foram [...] ditados por força de lei, assim como os limites da jornada de trabalho" 69 , é apenas porque

essas determinações minuciosas, que regulam o período, limites, pausas no trabalho de modo tão militarmente uniforme de acordo com o bater do sino, não eram, de modo algum, produto de alguma fantasia parlamentar. Desenvolveram-se progressivamente das próprias circunstâncias, como leis naturais do modo de produção moderno. Sua formulação, reconhecimento oficial e proclamação pelo Estado forma o resultado de prolongadas lutas de classes $^{70}$.

A crescente participação política dos trabalhadores (eleitoral, sindical etc.) sacará a luta de classes das sombrias fábricas onde se processava velozmente o desenvolvimento do processo de industrialização e a levará para o centro do debate político, sendo cada vez maior o número de "reivindicações não mais ignoráveis do proletariado" ". Pode-se dizer, agora, que a ambiguidade do direito radica no mesmo ponto onde se dá a inversão fetichista fundamental para o capital: o processo de produção.

Marx vai advertir, então, que este encontro entre comprador e vendedor da força de trabalho, totalmente mediado por categorias jurídicas que formalizam (fetichizam) os sujeitos e as coisas envolvidas, é o cerne do problema: "Em antítese às outras mercadorias, a determinação do valor da força de trabalho contém [...] um elemento histórico e moral”. Se, de um lado, "O proprietário da força de trabalho é mortal" ${ }^{\text {, }}$, de outro, "O capital é trabalho morto, que apenas se reanima, à maneira dos vampiros, chupando trabalho vivo e que vive tanto mais quanto mais trabalho vivo chupa"73.

Quando Marx fala em luta de classes, fala de algo que começa neste momento, neste encontro fundamental em que se dá a extração da mais-valia e a separação entre produtor direto e produto do trabalho, sob a faca afiadíssima da propriedade privada dos meios de produção. É no espaço da fábrica, diante da máquina, que o trabalhador "tem de se relacionar com sua força de trabalho como sua propriedade e, portanto, sua própria

\footnotetext{
${ }^{68}$ Karl MARX, O capital [col. Os Economistas], vol. I, t. 1, p. 215.

${ }^{69}$ Karl MARX, O capital [col. Os Economistas], vol. I, t. 1, p. 216.

${ }^{70}$ Karl MARX, $O$ capital [col. Os Economistas], vol. I, t. 1, p. 224.

${ }^{71}$ Karl MARX, O capital [col. Os Economistas], vol. I, t. 1, p. 17.

${ }^{72}$ Karl MARX, $O$ capital [col. Os Economistas], vol. I, t. 1, p. 141.

${ }^{73}$ Karl MARX, O capital [col. Os Economistas], vol. I, t. 1, p. 189.
} 
mercadoria, e isso ele só pode à medida que ele a coloca à disposição do comprador apenas provisoriamente, por um prazo de tempo determinado, deixando-a ao consumo, portanto, sem renunciar à sua propriedade sobre ela por meio de sua alienação"74.

Nas diversas vezes em que, durante a vida de Marx e de Engels, este conflito se desdobrou de forma política e jurídica, os autores do Manifesto Comunista não deixaram de exaltar a importância de interferir com tais instrumentos, que resultam da luta de classes, na própria luta de classes, nos diversos níveis e "rounds" em que ela se desenvolva. Como a medida da transformação da força de trabalho em mercadoria é o tempo, a disputa sobre a jornada de trabalho não poderia deixar de ser a mais mobilizadora, tanto prática quanto teoricamente. $\mathrm{Na}$ "Mensagem inaugural da Associação Internacional dos Trabalhadores" (1864), Marx avalia uma etapa desse processo:

Após uma luta de trinta anos, travada com a mais admirável perseverança, as classes operárias inglesas, aproveitando uma discórdia momentânea entre os senhores da terra e os senhores do dinheiro, conseguiram alcançar a Lei das Dez Horas. Os imensos benefícios físicos, morais e intelectuais daí resultantes para os operários fabris, semestralmente registados nos relatórios dos inspectores de fábricas, de todos os lados são agora reconhecidos. A maioria dos governos continentais teve de aceitar a Lei Fabril [Factory Act] inglesa em formas mais ou menos modificadas e o próprio Parlamento inglês foi cada ano compelido a alargar a sua esfera de acção.

Mas, para além do seu alcance prático, havia algo mais para realçar o maravilhoso sucesso desta medida dos operários. Através dos seus órgãos de ciência mais notórios - tais como o Dr. Ure, o Professor Sénior e outros sábios desse cunho -, a classe média tinha predito, e a contento dos seus corações, provado, que qualquer restrição legal às horas de trabalho teria de dobrar a finados pela indústria britânica que, qual vampiro, não podia senão viver de chupar sangue, e ainda por cima sangue de crianças. Em tempos idos, o assassínio de crianças era um rito misterioso da religião de Moloch, mas só era praticado em algumas ocasiões muito solenes, uma vez por ano, talvez, e, mêsmo assim, Moloch não tinha uma propensão exclusiva para os filhos dos pobres. Esta luta acerca da restrição legal das horas de trabalho enfureceu-se tanto mais ferozmente quanto, à parte a avareza assustada, ela se referia, na verdade, à grande contenda entre o domínio cego das leis da oferta e da procura que formam a economia política da classe média e a produção social controlada por previsão social, que forma a economia política da classe operária. Deste modo, a Lei das Dez Horas não foi apenas um grande sucesso prático; foi a vitória de um princípio; foi a primeira vez que em plena luz do dia a economia política da classe média sucumbiu à economia política da classe operária. ${ }^{75}$

\footnotetext{
${ }^{74}$ Karl MARX, O capital [col. Os Economistas], vol. I, t. 1, p. 139.

${ }^{75}$ MARX, ENGELS, Obras escolhidas, t. 2, p. 11.
} 
Não se vai aqui incorrer na leviandade de afirmar que Marx e Engels, justamente eles, confundiram as precárias possibilidades de luta por direitos com a neutralidade desses direitos. Como disse Rosa Luxemburgo, "todas as relações fundamentais da dominação da classe capitalista não são possíveis de transformação pelas reformas legais na base da sociedade burguesa, porque não foram introduzidos por leis burguesas, e nem receberam a forma de tais leis" ${ }^{\$ 7}$. O direito é, sem dúvida, muito mais frágil do que aparenta e não é ele que suporta as relações de classe. Ao contrário, suporta-se sobre elas, mas, naquele que podemos considerar como o embrião da legislação social, o que Marx e Engels viam era a oportunidade de lutar em melhores condições contra "a inevitável dominação temporária da democracia burguesa", fazendo uso dos caminhos abertos pela política "inimiga" para radicalizá-la na forma de ataques ao capital e aos seus sustentáculos. ${ }^{77}$ Ou ainda, mais uma vez com as palavras revolucionárias de Rosa Luxemburgo, analisando a ascensão da burguesia: as reformas legais não tornam inútil a tomada efetiva do poder pelos trabalhadores, mas servem para "prepará-la e provocá-la"78.

Marx, que sabia "seguir a luta de classes na história do dia-a-dia"79, tinha muita clareza quanto às limitações e mesmo os perigos da luta proletária ser orientada pelo direito, pois resultaria na aceleração da dominação capitalista:

Se a generalização da legislação fabril tornou-se inevitável como meio de proteção física e espiritual da classe operária, ela, por outro lado, generaliza e acelera, como já foi aventado, a metamorfose de processos de trabalho esparsos realizados em pequena escala em processos de trabalho combinados e em larga escala social, portanto a concentração do capital e o domínio exclusivo do regime de fábrica. Ela destrói todas as formas antiquadas e transitórias, atrás das quais a dominação do capital ainda se esconde em parte, e as substitui por sua dominação direta, indisfarçada. Generaliza, com isso, também, a luta direta contra essa dominação. Enquanto impõe nas oficinas individuais uniformidade, regularidade, ordem e economia, aumenta, por meio do imenso estímulo que a limitação e a regulamentação da jornada de trabalho impõe à técnica, a anarquia e as catástrofes da produção capitalista em seu conjunto, a intensidade do trabalho e a concorrência da maquinaria com o trabalhador. Com as esferas da pequena empresa e do trabalho domiciliar, aniquila os últimos refúgios dos “excedentes" e conseqüentemente a válvula de segurança até agora existente de todo o mecanismo da sociedade. Com as condições materiais e a combinação social do processo de produção,

\footnotetext{
${ }^{76}$ Rosa LUXEMBURGO, Reforma ou revolução?, p. 99.

77 "Mensagem da Direcção Central à Liga dos Comunistas" (1850), in MARX, ENGELS, Obras escolhidas, t. 1 , p. 185 .

${ }_{78}^{78}$ LUXEMBURGO, Rosa. Reforma ou revolução?, p. 99.

79 “Trabalho assalariado e capital” (1849), in MARX, ENGELS, Obras escolhidas, t. 1, p. 151.
} 
amadurece as contradições e os antagonismos de sua forma capitalista e portanto, ao mesmo tempo, os elementos constitutivos de uma nova e os momentos revolucionadores da velha sociedade. ${ }^{80}$

De qualquer modo, lutar com as armas burguesas da democracia e do direito contra a própria burguesia era - e ainda o é - condição de sobrevivência, não apenas política, dos trabalhadores. E é interessante notar que, para Marx e Engels, ao contrário de diversos autores posteriores, não havia uma contradição entre, como dizia Marx, um "movimento mais amplo" e as "lutas de todos os dias" contra o capital. Havia, claro, um persistente esclarecimento quanto à diferença entre elas e, mais ainda, a afirmação clara de que tais lutas cotidianas por si só mais reafirmavam do que atacavam o capital.

Neste sentido, Marx chega mesmo a indicar que, quanto mais particularmente relacionadas ao trabalho sejam essas lutas, mais úteis serão para os trabalhadores. Assim, não sem forte ironia, coloca de lado os direitos humanos, com sua pretensa universalidade, e defende que os trabalhadores lutem como classe pelos direitos que estão mais próximos da realidade que enfrentam no cotidiano das fábricas:

Como "proteção" contra a serpente de seus martírios, os trabalhadores têm de reunir suas cabeças e como classe conquistar uma lei estatal, uma barreira social intransponível, que os impeça a si mesmos de venderem a si e à sua descendência, por meio do contrato voluntário com o capital, à noite e à escravidão! No lugar do pomposo catálogo dos “direitos inalienáveis do homem” entra a modesta Magna Charta de uma jornada de trabalho legalmente limitada que "finalmente esclarece quando termina o tempo que o trabalhador vende e quando começa o tempo que a ele mesmo pertence". 81

A legalidade assume um papel tanto protetivo quanto organizativo que não poderá ser colocado de lado pelos trabalhadores e, mais ainda, passará a representar um grande incômodo para a classe que dela mais se beneficia, pois das reivindicações econômicas desdobra-se a organização política dos trabalhadores na forma dos partidos, visando a disputa por espaços até então ocupados apenas pela classe proprietária. Engels, na citada "Introdução" de 1895, afirma até que, diante deste novo estágio das lutas de classes, "tanto a burguesia como o governo vieram a ter mais medo da acção legal do que da ilegal do partido operário, a recear mais os êxitos eleitorais do que os da rebelião". 82

\footnotetext{
${ }^{80}$ Karl MARX, O capital [col. Os Economistas], vol. I, t. 1, p. 100.

${ }^{81}$ Karl MARX, $O$ capital [col. Os Economistas], vol. I, t. 1, p. 238.

${ }^{82}$ In MARX, ENGELS, Obras escolhidas, t.1, p. 200.
} 
Na visão de Engels, a forma competente como a classe trabalhadora passou a fazer uso da legalidade, essa arma sabidamente criada pelo e para o inimigo, chegou mesmo a inverter, contra os criadores, a necessidade de atacar sua criatura. São os burgueses que, para dar vazão a seus interesses, têm agora contra si a lei e o uso que dela fazem os partidos operários. Se quiserem vencer, os burgueses têm que vencer de acordo com a lei ou atacar o instrumento que legitima apenas e precisamente a sua classe:

A ironia da história universal põe tudo de cabeça para baixo. Nós, os "revolucionários", os "subversivos", prosperamos muito melhor com os meios legais do que com os ilegais e a subversão. Os partidos da ordem, como eles se intitulam, afundam-se com a legalidade que eles próprios criaram. Exclamam desesperados com Odilon Barrot: La legalité nous tue, a legalidade mata-nos, enquanto nós, com essa legalidade, revigoramos os nossos músculos e ganhamos cores nas faces e parecemos ter vida eterna. E se nós não formos loucos a ponto de lhes fazermos o favor de nos deixarmos arrastar para a luta de rua, não lhes restará outra saída senão serem eles próprios a romper esta legalidade tão fatal para eles. ${ }^{83}$

É por esta razão que se pode dizer, com acerto, que "A história dos séculos XIX e $\mathrm{XX}$ pode ser contada como uma saga: a resistência das camadas sociais mais desprotegidas contra as forças cegas e supostamente impessoais do mercado. O século XX foi, sem dúvida, palco de uma batalha que, entre mortos e feridos, deixou o saldo positivo da

\footnotetext{
${ }^{83}$ In MARX, ENGELS, Obras escolhidas, t.1, pp. 205/206. Mais de duas décadas antes, no "Discurso sobre a acção política da classe operária" (1871), Engels já havia anunciado as possibilidades do conflito de classes assumir esta nova feição: "A abstenção absoluta em matéria política é impossível; por isso, todos os jornais abstencionistas fazem política. Trata-se apenas de como se a faz e de qual. Quanto ao resto, para nós, a abstenção é impossível. O partido operário existe já como partido político na maior parte dos países. Não nos compete arruiná-lo, pregando a abstenção. A experiência da vida actual, a opressão política que lhes é imposta pelos governos existentes para fins quer políticos quer sociais, forçam os operários a ocuparem-se de política, quer eles queiram quer não. Pregar-lhes a abstenção seria empurrá-los para os braços da política burguesa. A seguir à Comuna de Paris, sobretudo, que pôs a acção política do proletariado na ordem do dia, a abstenção é completamente impossível.

Nós queremos a abolição das classes. Qual é o meio de a ela chegar? A dominação política do proletariado, e quando todas as partes estão de acordo com isso, pedem-nos para não nos metermos em política! Todos os abstencionistas se dizem revolucionários e mesmo revolucionários por excelência. Mas a revolução é o acto supremo da política; quem a quer tem de querer o meio, a acção política, que a prepara, que dá aos operários a educação para a revolução, e sem a qual os operários, no dia a seguir à luta, serão sempre os enganados pelos Favre e pelos Pyat. Mas a política que é preciso fazer é a política operária; é preciso que o partido operário seja constituído não como a cauda de qualquer partido burguês mas como partido independente que tem o seu objectivo, a sua política própria.

As liberdades políticas, o direito de reunião e de associação e a liberdade de imprensa, eis as nossas armas; e deveríamos cruzar os braços e abstermo-nos se no-las querem tirar? Diz-se que todo o acto político implica que se reconheça o estado existente das coisas. Mas quando esse estado das coisas nos dá meios para protestar contra ele, usar esses meios não é reconhecer o estado existente" - In MARX, ENGELS, Obras escolhidas, t. 2, pp. 267/268 (grifos nossos).
} 
conquista dos direitos sociais" ${ }^{\prime 84}$. Se as condições históricas em que se encontrava o Brasil o excluíram quase completamente dessa história no século XIX, não resta dúvida de que, já no século XX, há parte importante dela que pode também ocorre aqui.

Trata-se, então, das lutas sociais e dos processos políticos que resultaram nas leis trabalhistas brasileiras. ${ }^{85}$ Apesar da conhecida história dos usos políticos conservadores da legislação social ${ }^{86}$ e de sua precisa crítica como instrumento de dominação burguês ${ }^{87}$, não se pode afirmar que tais direitos tenham surgido sem lutas - tanto nos casos observados

${ }^{84}$ Luiz Gonzaga BELLUZZO, "O mercado e os direitos sociais", in Ensaios sobre o capitalismo no século $X X$, p. 64.

${ }^{85}$ A propósito da evolução histórica da legislação trabalhista brasileira, ver Jorge Luiz Souto Maior, "Breves considerações sobre a história do Direito do Trabalho no Brasil", in Marcus Orione Gonçalves CORREIA (org.), Curso de Direito do Trabalho - vol. I, pp. 63/83. Ver, também, as análises de José Murilo de CARVALHO, Cidadania no Brasil, pp. 110-126, 170-173, 206-209

86 "as leis trabalhistas estabeleceram a legitimidade dos sindicatos operários, protegeram-nos e aos seus funcionários contra a perseguição dos empregadores e, por fim, forneceram um mecanismo para julgamento de disputas não totalmente subservientes aos empregadores. Todavia, essas medidas restringiram estreitamente as áreas de ação legal, estabeleceram os sindicatos de forma que limitava severamente sua capacidade de promover os interesses dos trabalhadores, e tornaram difíceis as ações coletivas conseqüentes dos trabalhadores" - Michael M. Hall, "Corporativismo e fascismo: as origens das leis trabalhistas brasileiras", in Ângela ARAÚJO (org.). Do corporativismo ao neoliberalismo, p. 26.

87 "Quanto ao direito do trabalho, as transformações determinantes são aquelas pelas quais passou o capitalismo mundial a partir da Primeira e principalmente após a Segunda Guerra Mundial, com o fortalecimento dos movimentos operários e a ascensão da 'ameaça comunista' no leste europeu. Embora muitos insistam em remontar a história do surgimento do direito do trabalho à Primeira Revolução Industrial ou, de maneira equívoca, a períodos até mesmo anteriores ao capitalismo, as razões autênticas para o reconhecimento de desigualdades no contrato de trabalho residem no contexto de instabilidades sociais que, de maneira geral, resultou na substituição do Estado liberal pelo Estado social ou intervencionista. Para afastar o 'perigo' e garantir as condições gerais de perpetuação da produção capitalista, foi necessária a intervenção do Estado no domínio das relações contratuais, a interferência no equilíbrio das partes no pacto entre trabalhador e empregador.

O que pretendo deixar claro é que a exploração dos trabalhadores não foi a causa principal do direito do trabalho. Não foi com o intuito de acabar com a exploração que este ramo do direito nasceu. Ao contrário, o intuito da proteção jurídica ao trabalhador é reduzir o grau da exploração para manter a exploração possível em última instância, seu intuito é conter insatisfações de modo a assegurar que a massa dos trabalhadores continue colocando a produção em movimento. Mesmo um defensor radical do 'direito social', como foi o perspicaz Cesarino Júnior, demonstra ter consciência disso. Rebatendo o argumento de que o direito do trabalho seria uma modalidade de privilégio, ele defende que a proteção à parte 'mais fraca' na relação de trabalho é um interesse geral, pois serve, na realidade, de meio para assegurar a 'paz social'. E é ainda mais claro em outro ponto, quando discute a eficiência dos mecanismos jurídicos para, isolados, resolverem aquilo que chamou de 'questão social': os empregadores devem 'concordar em perder os anéis para assegurar a conservação dos dedos'.

$\mathrm{O}$ que sempre esteve em jogo no direito do trabalho não foi a proteção à pessoa do trabalhador, mas a proteção à organização produtiva fundada na operação pela qual o trabalhador entrega sua força de trabalho ao empregador por intermédio de um negócio jurídico. Proteger o trabalhador foi o meio encontrado para um certo fim - proteger uma certa paz social, a paz social do capitalismo. Tanto é assim que, tão breve quanto desapareceram as contingências ameaçadoras, isto é, com a desmobilização dos trabalhadores e o desaparecimento de qualquer concorrente visível da ordem social estabelecida, diante daquilo que hoje se conhece como o 'novo liberalismo', já se fala em 'flexibilizar' o direito do trabalho. A proteção jurídica do trabalhador se tornou entrave a superar no caminho do capital" - Celso Naoto KASHIURA JÚNIOR, Crítica da Igualdade Jurídica, pp. 158/160. Ver, ainda, a análise de Graciela Bensusan, "Direito do Trabalho: seu papel na organização da dominação: o caso do México", in Carlos Alberto PLASTINO (org.), Crítica do direito e do estado, pp. 121/133. 
por Marx e Engels, quanto no brasileiro. No Brasil, difunde-se ainda o mito da concessão paternalista dos direitos aos trabalhadores, mas, nas palavras de Ricardo Antunes:

Contra o mito do pai dos pobres, é necessário enfatizar que, desde a segunda metade do século XIX e especialmente as primeiras décadas do século XX, o movimento operário, em seus embates cotidianos, exigia a criação de uma legislação social que garantisse os direitos do trabalho, como se pode constatar no heróico exemplo da greve geral de 1917, brutalmente reprimida pela República Velha, entre tantas outras que ocorreram ao longo da primeira metade dos anos 1930, quando se gestou a legislação social getulista. ${ }^{88}$

Esse histórico de lutas sociais - que está na base dos importantes sindicatos e partidos operários que num mesmo período histórico, relativamente curto, surgiram por todo o mundo ${ }^{89}$ - é, claro, tão interessante para os trabalhadores, considerando a dimensão mais imediata da melhoria de suas condições de trabalho, quanto para o capitalismo, que consegue saltar sobre suas crises, ainda que capitalistas assim não vejam ${ }^{90}$. Do ponto de vista político, o historiador José Murilo de Carvalho afirma:

"O populismo, no Brasil, na Argentina, ou no Peru, implicava uma relação ambígua entre os cidadãos e o governo. Era avanço da cidadania, na medida em que trazia as massas para a política. Mas, em contrapartida, colocava os cidadãos em posição de dependência perante os líderes, aos quais votavam lealdade pessoal pelos benefícios que eles de fato ou supostamente lhes tinham distribuído. A antecipação dos direitos sociais fazia com que os direitos não fossem vistos como tais,

88 "Construção e desconstrução da legislação social no Brasil”, in Ricardo ANTUNES (org.), Riqueza e miséria do trabalho no Brasil, p. 501. No mesmo sentido, merece destaque o trabalho seminal de Adalberto PARANHOS, O roubo da fala, em que o autor demonstra que a ideologia do trabalhismo no Brasil é uma "fala roubada aos trabalhadores", fazendo parecer concessão do getulismo aquilo que, na verdade, era em grande medida conquista das lutas operárias.

89 Para um detalhado histórico deste processo, como parte da contribuição das "esquerdas" - desde a Revolução Francesa até o final do século XX na Europa - para as conquistas sociais e democráticas, ver a obra de Geoff ELEY, Forjando a democracia: a história da esquerda na Europa 1850-2000. E também remeto a Giacomo MARRAMAO, O político e as transformações, sobre o início do século XX.

90 "Dada a hostilidade da classe capitalista à instauração de direitos sociais, é desarrazoado supor que tal processo tenha sido, nas sociedades capitalistas concretas onde ele ocorreu, uma conseqüência natural da instauração, num momento inicial, das liberdades civis elementares. É verdade que as classes trabalhadoras puderam se apoiar nos direitos civis vigentes para reivindicar certos direitos sociais, argumentando muitas vezes que só a criação de novas condições materiais de trabalho, vida e consumo daria um conteúdo a liberdades civis até então só vigentes no plano formal. Contudo, nessa luta por direitos sociais as classes trabalhadoras tiveram de enfrentar regularmente a oposição da classe capitalista, para quem os direitos sociais representariam uma violação ou deformação dos direitos civis. É inconveniente, portanto, definir a instauração de direitos sociais como uma etapa necessária e irreversível da evolução política de qualquer sociedade capitalista. Tais direitos, assim como foram instaurados, podem ser revogados; é de resto o que está ocorrendo, de modo parcial porém progressivo, em muitas sociedades capitalistas atuais onde os governos implementam políticas neoliberais" - Décio Azevedo Marques SAES, "Direitos sociais e transição para o capitalismo: o caso da primeira república brasileira (1889-1930)”, p. 26. 
como independentes da ação do governo, mas como um favor em troca do qual se deviam gratidão e lealdade. A cidadania que daí resultava era passiva e receptora antes que ativa e reivindicadora". ${ }^{91}$

Obviamente, esta não seria a solução ideal para os conflitos colocados pelos trabalhadores a partir de suas preocupações particulares. No entanto, Gilberto Bercovici chama atenção para o fato de que "a cidadania dos trabalhadores, no Brasil, foi alcançada não pelos direitos políticos, mas pelos direitos sociais, definidos por lei”. Em sua análise, tal diferença ressalta mais uma vez a importância dos direitos - das diversas lutas que nele estão envolvidas, de sua produção à efetivação ou negação - para a consciência dos trabalhadores a respeito de sua condição social específica:

A questão fundamental, na realidade, passa a ser a da efetividade da CLT e o seu cumprimento pelo Estado, por patrões e pela Justiça do Trabalho. A legislação trabalhista teve (e tem) este importante papel: o de criar uma cultura "jurídica" ou "legal" dos trabalhadores. Com a CLT, muitas vezes, o Estado foi utilizado para coibir violações de direitos por parte dos empregadores. Afinal, os trabalhadores não reivindicam nada mais do que o cumprimento da lei. A conquista dos direitos trabalhistas, em última instância, está ligada ao reconhecimento da dignidade dos trabalhadores ${ }^{92}$.

Falar, portanto, na ambiguidade do direito, especialmente no caso dos direitos sociais, como abertura e estímulo às reivindicações sociais, deve levar em consideração não apenas a crítica teórica mais imediata, mas a verificação das múltiplas determinações que estão envolvidas no curso das lutas de classes históricas, tanto no que diz respeito à alteração das instituições políticas e jurídicas que operam o arranjo ideológico do capital ${ }^{93}$, quanto às implicações que aquelas lutas podem ter sobre a consciência das classes sociais, em especial a classe trabalhadora, fragilizando o fetichismo ${ }^{94}$ e permitindo sua contestação, inicialmente, e, claro, também o ataque às injustiças por ele recobertas.

${ }^{91}$ José Murilo de CARVALHO, Cidadania no Brasil, p. 126.

${ }^{92}$ Gilberto BERCOVICI, Constituição econômica e desenvolvimento, pp. 22/23.

93 Leia-se: "o regime político, exprimindo a forma fenomênica pela qual o Estado transparece, varia de conformidade com a situação histórica e o caráter e intensidade da luta de classes, segundo a conjuntura das forças econômicas e políticas em jogo em um certo período histórico de determinada formação social. Em razão dessa conjuntura, a burguesia, apoiada ou não pelo bloco no poder, se vê em muitas ocasiões, por suas frações e setores, obrigada a transigir exatamente para persistir e dar continuidade ao processo de acumulação capitalista" - Alaôr Caffé ALVES, Estado e ideologia, p. 247.

94 Ver ainda, neste sentido, "O surgimento do antivalor", in Francisco de OLIVEIRA, Os direitos do antivalor, pp. 35-36. Francisco de Oliveira afirma que os chamados "direitos do antivalor" - os direitos sociais - implicam uma espécie de "anulação do fetiche da mercadoria", com relação à força de trabalho, tendo em vista que, "cada vez mais, a remuneração da força de trabalho é transparente, no sentido de que seus componentes são não apenas conhecidos, mas determinados politicamente". Para o autor, "Pode-se, apenas, sugerir que no lugar do fetiche da mercadoria colocou-se um fetiche do Estado, que é finalmente o 


\title{
2.3. Uma teoria da ideologia jurídica
}

A observação da realidade da luta de classes e a constatação do papel relevante que o direito desempenha - ao ocultar sob a capa da universalidade os interesses particulares da classe dominante, mantendo, entretanto, os interesses antagônicos como possibilidades reivindicáveis - desafiam a teoria da ideologia jurídica a levar em consideração fatores materiais que normalmente são deixados de lado na crítica à mistificação que encobre a essência do direito. É precisamente o que afirma Pachukanis:

\begin{abstract}
A perfeição formal dos conceitos de "território nacional", de "população", de "poder Estatal" não reflete apenas uma determinada ideologia, mas, também, a realidade objetiva da formação de uma esfera concentrada de dominação, e, mais, a criação de uma organização administrativa, financeira e militar real com uma estrutura humana e material correspondente. [...] Será que o professor Rejsner acredita que os caminhos militares romanos ou os modernos meios de comunicação fazem parte do psiquismo humano? Ou pensa que tais elementos materiais não devem ser computados entre os elementos de formação do Estado? Evidentemente, então, só nos resta colocar no mesmo plano a realidade estatal e a realidade da "literatura, da filosofia e de outras produções espirituais do homem". É pena que a prática da luta política, da luta pelo poder, contradiga radicalmente esta concepção psicológica e oponha a cada etapa elementos materiais e objetivos. ${ }^{95}$
\end{abstract}

Não se pode reduzir a ideologia, portanto, a uma simples manifestação psicológica da inversão dada na realidade, mas, pelo contrário, deve-se considerar os elementos reais sobre os quais e por meio dos quais ela atua. A sua crítica, portanto, deve ser a crítica da totalidade, como já havia percebido exaustivamente Marx. Se o fetichismo resulta de um processo real e desencadeia seus efeitos concretamente desde a particularidade do trabalho até a totalidade das relações sociais do capital, deve-se concluir que sua crítica deve ser sempre a revelação daquele processo em todas as suas dimensões e a constituição de uma consciência prática capaz de desafiá-lo. Como diz ainda Mészáros:

$\mathrm{Na}$ verdade, a ideologia não é ilusão nem superstição religiosa de indivíduos mal-orientados, mas uma forma específica de consciência social, materialmente ancorada e sustentada. Como tal, não pode ser superada nas sociedades de classes. Sua persistência se deve ao fato de ela ser constituída objetivamente (e constantemente reconstituída) como consciência prática inevitável das sociedades

lugar onde se opera a viabilidade da continuação da exploração da força de trabalho, por um lado, e de sua des-mercantilização, por outro, escondendo agora o fato de que o capital é completamente social".

${ }^{95}$ E. B. PASUKANIS. A teoria geral do direito e o marxismo, pp. 44/45. 
de classe, relacionada com a articulação de conjuntos de valores e estratégias rivais que tentam controlar o metabolismo social em todos os seus principais aspectos. Os interesses sociais que se desenvolvem ao longo da história e se entrelaçam conflituosamente manifestam-se, no plano da consciência social, na grande diversidade de discursos ideológicos relativamente autônomos (mas, é claro, de modo algum independentes), que exercem forte influência sobre os processos materiais mais tangíveis do metabolismo social.

Uma vez que as sociedades em questão são elas próprias internamente divididas, as ideologias mais importantes devem definir suas respectivas posições tanto como "totalizadoras" em suas explicações e, de outro, como alternativas estratégicas umas às outras. Assim, as ideologias conflitantes de qualquer período histórico constituem a consciência prática necessária em termos da qual as principais classes da sociedade se inter-relacionam e até se confrontam, de modo mais, ou menos, aberto, articulando sua visão da ordem social correta e apropriada como um todo abrangente". ${ }^{96}$

A constituição dessa consciência prática, que se apropria dos elementos colocados pelas classes em seu intercâmbio histórico, certamente tem no direito um de seus mais importantes pilares, tanto mais pela maneira como no último século, na forma dos direitos sociais, ele tem sido aplicado para equacionar os interesses do capital e do trabalho. Em outras palavras, se o direito assume papel progressivamente relevante no conjunto da ideologia social, ao perfazer em normas jurídicas a regulação das mais variadas esferas da vida - que nele recebem um detalhamento também cada vez maior -, a este movimento corresponde outro igualmente importante: queira ou não, é com o direito que vai se defrontar toda e qualquer reivindicação social; de outra parte, por ser inevitável lutar sobo direito, o aumento dessas lutas pode significar o esgarçamento da "solução" jurídica e a restituição de outras formas de luta. Não se pode, entretanto, esquecer que:

\begin{abstract}
o Direito, no sistema capitalista, já é a expressão permanente e continuada da própria crise e tensão contraditória inerentes a esse sistema, umas vezes mais agudas, outras, menos. A real e viva conexão entre a ordem de relações econômicas e sociais dominantes na sociedade civil burguesa e o sistema formal de Direito vigente disciplinador de tal ordem não se pode revelar, na perspectiva dialética da sociedade, como "exterior" a essa mesma ordem e sistema. Ao possibilitar um espaço juridicamente neutro para a perseguição legítima do interesse privado, o Direito traduz em si mesmo essa oposição e ao mesmo tempo a unidade em razão das quais o próprio sistema formal e a ordem capitalista existem como condições mútuas e intrínsecas, um do outro. ${ }^{97}$
\end{abstract}

\footnotetext{
${ }^{96}$ István MÉSZÁROS, O poder da ideologia, p. 65.

97 Alaôr Caffé ALVES, Estado e ideologia, p. 313. “o Direito, no sistema capitalista, já é a expressão permanente e continuada da própria crise e tensão contraditória inerentes a esse sistema, umas vezes mais agudas, outras, menos. A real e viva conexão entre a ordem de relações econômicas e sociais dominantes na sociedade civil burguesa e o sistema formal de Direito vigente disciplinador de tal ordem não se pode revelar,
} 
Neste quadro, se o direito, "ao ocultar sua essência, perfaz sua própria realidade na exata medida em que a oculta" ${ }^{\text {"9 }}$, é consequente a afirmação de que a ideologia jurídica não pode ser apreendida apenas como uma forma de desacreditar as leis e demais instituições como instrumentos de luta por serem "frutos da árvore venenosa" da dominação burguesa. Falar em ideologia jurídica, portanto, é falar de um processo muito mais complexo ou, mais precisamente, dialético, em que se percebe que o fetichismo que as relações jurídicas lançam sobre a totalidade das relações sociais resulta também na potente fetichização do próprio direito, que atinge - em medidas desiguais - os dois lados do conflito, tendo em vista que, de fato, ao discurso que apresenta o direito como um "terceiro desinteressado", que decide os conflitos a partir de uma posição "superior e equidistante", correspondem, na realidade, com poderes concretos, instituições públicas que inevitavelmente absorvem parte do impacto das classes sociais em permanente luta e, mais que isso, correspondem também expectativas sociais que originaram ou resultaram dos direitos.

Assim, se o direito definitivamente não é neutro, também não é unilateral, pois é incapaz de se legitimar e, consequentemente, proteger a reprodução do capital se afirmar todas as suas previsões diretamente em uma única direção (indiretamente, todavia, talvez ocorra). Necessário citar, ainda uma vez, as palavras de Mészáros:

Sendo a ideologia a consciência prática inevitável das sociedades de classe, articulada de modo tal que os membros das forças sociais opostas possam se tornar conscientes de seus conflitos

na perspectiva dialética da sociedade, como "exterior" a essa mesma ordem e sistema. Ao possibilitar um espaço juridicamente neutro para a perseguição legítima do interesse privado, o Direito traduz em si mesmo essa oposição e ao mesmo tempo a unidade em razão das quais o próprio sistema formal e a ordem capitalista existem como condições mútuas e intrínsecas, um do outro".

${ }^{98}$ Cito as palavras utilizadas por Alaôr Caffé ALVES para tratar do Estado: "o Estado aparece, no mundo fenomênico, precisamente como aquilo que ele não é; porém, esse modo negativo de aparecer, esse modo de não ser, é fundamental e necessário para que o Estado seja o que ele realmente é; ao ocultar sua essência, ele perfaz sua própria realidade na exata medida em que a oculta" - Estado e ideologia, p. 19. Diz ainda o autor: "A expansão, desenvolvimento e fortalecimento da atividade do Estado, através de suas inúmeras agências públicas, representam o aumento das mediações estruturais que lhe propiciam maior grau de autonomia relativa. Esta se traduz no reforço da aparência ideológica do Estado como agente social neutro, como gestor eqüidistante e indiferente das contradições estruturais da sociedade de classes, das quais ele mesmo é também produto. Esse processo, seguido da eficiência burocrática, racionalização dos meios de intervenção e formalização jurídica, tende a ampliar as bases de legitimação do poder, como resposta às crises sociais e econômicas cada vez mais agudas, originadas do aprofundamento das contradições para cujo mascaramento concorre esse mesmo esforço de legitimação hegemônica" - idem, p. 16. Em texto mais recente, prossegue: “É preciso, entretanto, notar que o Estado não é uma 'coisa' totalmente dominada pela burguesia. Ele é uma relação dinâmica entre o poder hegemônico e o poder dominado, em que se pode observar sua maior ou menor inclinação para os programas sociais, dependendo do grau de luta e pressão entre as classes sociais. Assim, não existe um poder único e excludente do poder dominado. E este último não é nulo; ele tem certa densidade e é apenas um poder subordinado" - "Fundamentos do direito e meio ambiente", p. 341. 
materialmente fundados e lutar por eles, a questão verdadeiramente importante é a seguinte: os indivíduos, equipados com a ideologia da classe a que pertencem, ficarão do lado da causa da emancipação, que se desdobra na história, ou se alinharão contra ela? A ideologia pode (e de fato o faz) servir a ambos os lados com seus meios e métodos de mobilização dos indivíduos que, ainda que não percebam com clareza o que ocorre, inevitavelmente participam da luta em andamento. ${ }^{99}$

Do que foi dito, resulta que a ideologia jurídica deve ser compreendida numa nova perspectiva, mais afinada com a riqueza conceitual do fetichismo em Marx e também com sua (e, claro, de Engels) permanente disposição para travar os combates políticos que podem influenciar na luta de classes. Assim, se nesta perspectiva não estiver de uma vez por todas definido o que a ideologia é, que ao menos não reste dúvida quanto ao que ela não é: simplesmente um reflexo tão invertido quanto passivo dos conflitos sociais. Se a ideologia resulta do movimento histórico da sociedade de classes, é em movimento (e apenas em movimento) que surge alguma chance de capturá-la com seu sentido vivo, mas não de congelá-la para uso em outras experiências laboratoriais... O próprio percurso que o conceito desenvolve nas obras de Marx pode ser uma prova disso.

Nas páginas seguintes, o presente trabalho percorre justamente as trilhas dos direitos sociais e das lutas de classes em nosso momento histórico. Como diz Leandro Konder, refletindo sobre a questão da ideologia: "Embora [...] a solução de problemas teóricos cruciais dependa da ação prática, convém fazer a ressalva de que a ação prática capaz de resolver esses problemas precisa, ela mesma, da teoria". 100

${ }^{99}$ István MÉSZÁROS, O poder da ideologia, p. 327.

${ }^{100}$ Leandro KONDER, A questão da ideologia, p. 265. 


\section{DIREITOS SOCIAIS E NEOLIBERALIZAÇÃO}

\subsection{Direito e política na Constituição de 1988}

A dinâmica entre conservação e transformação da sociedade, que caracteriza a ambiguidade do direito e, em especial, dos direitos sociais encontra na Constituição de 1988 um exemplo preciso. Mesmo numa observação rápida de seus artigos é possível concluir que se trata exatamente de uma Constituição que se propõe mais a transformar do que a conservar a sociedade: desde a forma como foram fixados os seus princípios fundamentais até a decisão sobre quais são os objetivos fundamentais da República, passando por artigos que detalham como devem ser respeitados aqueles princípios e alcançados estes objetivos, todo o texto constitucional pode ser lido como um projeto para transformar profundamente a sociedade brasileira. Um país que, após os anos de ditadura militar, pouco tinha a conservar, é normal que se apresente constitucionalmente por meio de um grande e quase revolucionário projeto de transformação.

Se, no entanto, é imediata a acusação do caráter programático ou dilatório de suas normas, o esforço neoliberal experimentado durante a década seguinte à sua promulgação a fim de desfigurar o texto original (com sucessivas emendas e até mesmo propostas de nova Constituinte) ensina que a Constituição, na ausência de solução mais profunda, é instrumento e campo de luta social, tão caro quanto indeclinável, merecendo toda a atenção dos grupos dominados, sob pena de sua dominação se converter em uma espécie de subjugação completa e fatal. Mas a Constituição brasileira pode ser considerada no mesmo plano de outras, históricas, como a Mexicana (1917) ou a de Weimar (1919), que surgiram para "acalmar" forças sociais que seriam capazes de transformar radicalmente a sociedade em direção à superação do capitalismo? Havia, no Brasil dos anos 1980, forças sociais politicamente organizadas que pudessem determinar um novo rumo na organização social? Ou as forças de então (CUT, PT, MST, entre outras), o muito que poderiam era mesmo ver reconhecidos alguns direitos a mais na nova ordem constitucional?

Se não se pode afirmar que tais forças seriam capazes de uma transformação do Brasil para além do capital, até porque no contexto internacional os anos 1980 não foram exatamente os mais felizes para os revolucionários..., nem por isso deve-se negar que o novo arranjo que as forças sociais então ganhavam conseguia, sem dúvida, sustentar uma 
alteração significativa da sociedade e das instituições brasileiras na forma constitucional. Impossível, aqui, não abusar do preciso relato histórico de José Paulo Netto:

no processo de derrota da ditadura e sua substituição por um regime democrático - processo que se iniciou nos anos setenta e atravessou a década de oitenta -, a mobilização política de amplos setores populares alcançou tal magnitude que não foi possível evitar que se criassem as bases jurídicoinstitucionais para reverter boa parte daqueles traços de extrema exploração e dominação. A Constituição de 1988 consagrou este profundo avanço social, resultado das lutas conduzidas, por duas décadas, pelos setores democráticos: sem ferir a ordem burguesa (no interior da qual é impensável eliminar a exploração dos trabalhadores e a reprodução da miséria), ela assentou os fundamentos a partir dos quais a dinâmica capitalista poderia ser direcionada de modo a reduzir, a níveis toleráveis, o que os próprios segmentos das classes dominantes então denominavam "dívida social". $[\ldots]$

Neste sentido, o essencial da Constituição de 1988 apontava para a construção - pela primeira vez assim posta na história brasileira - de uma espécie de Estado de bem-estar social: não é por acaso que, no texto constitucional, de forma inédita em nossa lei máxima, consagram-se explicitamente, como tais e para além dos direitos civis e políticos, os direitos sociais (coroamento, como se sabe, da cidadania moderna). Com isto, colocava-se o arcabouço jurídico-político para implantar, na sociedade brasileira, uma política social compatível com as exigências de justiça social, eqüidade e universalidade.

Curiosamente, esta conquista social - insista-se: só possível pela amplitude da mobilização de setores populares na agonia do regime ditatorial e na transição à democracia política - realizava-se no mesmo momento em que, no plano internacional, múltiplos processos concorriam para colocar em questão o Estado de bem-estar social (processos que incluem, dentre outros componentes, a reestruturação do capitalismo mundial e a crise do chamado socialismo real). Assim, ao tempo em que, no Brasil, criavam-se mecanismos político-democráticos de regulação da dinâmica capitalista, no espaço mundial tais mecanismos perdiam vigência e tendiam a ser substituídos, com a legitimação oferecida pela ideologia neoliberal, pela desregulamentação, pela flexibilização e pela privatização - elementos inerentes à mundialização (globalização) operada sob o comando do grande capital. As possibilidades de levar à prática o essencial da Constituição de 1988, com esta evidente assincronia, tornavam-se mais problemáticas. [...]

Por isto mesmo, o desenho constitucional de 1988, logo que a Carta foi promulgada, configurou-se como o centro do debate político: para a massa dos trabalhadores a sua implementação representava a alternativa para reverter as conseqüências econômico-sociais mais dramáticas da herança da ditadura; para os setores ligados ao grande capital tratava-se precisamente de inviabilizar esta alternativa. Daí que, na seqüência da entrada em vigor da nova Constituição, a burguesia e seus sócios tenham jogado tudo para desqualificá-la (desde o impedimento da preparação da legislação complementar até a pura e simples violação de seus preceitos). 
Neste confronto, os setores dominantes começaram levando a melhor: foram capazes de um rearranjo político que lhes conferiu uma vitória eleitoral - a presidencial de 1989 -, que teve como efeito uma sensível desmobilização dos setores populares (desmobilização tanto mais rápida quanto menores tinham sido os ganhos organizativos do movimento popular). Mas o governo Collor, mais um caso de polícia que de política, não apenas desorganizou o Estado e tornou intolerável a corrupção escancarada: teve a função de deixar clara para a burguesia a necessidade de um projeto político orgânico e menos imediatista. O episódio Itamar Franco serviu para testar a liderança política apta para emprestar a este projeto uma face palatável - e, com o "Plano Real", FHC tornouse o homem confiável para conduzi-lo.

Confiável, em primeiro lugar, para o grande capital e seus detentores (a burguesia e seus associados, as grandes corporações transnacionais e seus representantes, situados também nos organismos financeiros tipo FMI e Banco Mundial): para sustentar a sua candidatura, maquiada de socialdemocrata, foi relevante o aval do PFL, partido que reúne a nata política provinda da ditadura; mas, também, confiável para boa parte da população trabalhadora, dadas as credenciais democráticas do candidato.

Vitorioso no primeiro turno, FHC rapidamente deu efetividade ao projeto político do grande capital: sua base parlamentar, articulada fisiologicamente e reunindo as velhas e novas oligarquias, garantiulhe precisamente a inviabilização do projeto social contido na Constituição de 1988 - sob o pretexto da "modernização do país", do "ingresso no Primeiro Mundo" e coisas que tais, e sustentado por uma unanimidade da mídia que nem a ditadura forçadamente obteve, o primeiro governo FHC operou eficientemente contra a alternativa social proposta na Constituição em dois planos: no plano jurídico, dando forma a uma reforma/revisão constitucional que acabou por retirar da Carta elementos fundamentais (neste sentido, a "reforma da previdência" é emblemática); e, substancialmente, no plano prático-concreto, dando curso a um "modelo de desenvolvimento" que subtraiu as bases de sustentação econômico-financeiras para uma eventual implementação daquela alternativa ${ }^{101}$.

Diante de tamanhas adversidades, o sucesso de uma Constituição com perfil social e distributivista não seria facilitado. Se as conquistas jurídicas são precárias, como já se afirmou aqui, é de se imaginar que, havendo um abismo tão profundo entre a luta social que conquistou os direitos e o contexto seguinte ${ }^{102}$, em que novas lutas sociais seriam

101 José PAULO NETTO, “FHC e a política social: um desastre para as massas trabalhadoras”, pp. 77/79.

${ }^{102} \mathrm{Na}$ lição de Gilberto BERCOVICI, a vida das constituições que antecederam a nossa em várias décadas (e a influenciaram) era a seguinte: "A ampliação dos direitos políticos e o conteúdo material dos direitos sociais tornou a pós-Segunda Guerra Mundial o período em que a emancipação e a reivindicação da democracia econômica e social chegaram ao seu momento mais elevado. No entanto, apesar dos avanços e conquistas, o Estado social do segundo pós-guerra e os trinta anos de "consenso keynesiano" acabaram por se revelar uma exceção na história do capitalismo. Além disto, as constituições sociais vão, desde o início, enfrentar vários obstáculos para sua concretização, sendo apenas parcialmente cumpridas. O núcleo emancipatório das constituições sociais, na prática, foi suspenso. A suspensão da constituição social, no entanto, vai se tornar evidente com a nova crise econômica, a partir da década de 1970, e a contra-revolução neoliberal conservadora que não se limita mais a suspender ou bloquear as cláusulas sociais das constituições, mas busca a sua extirpação formal do texto constitucional” - Soberania e Constituição, p. 321. 
necessárias para efetivá-los, possivelmente aqueles direitos todos encontrariam seu destino: o grande catálogo das expectativas frustradas da sociedade brasileira.

Importante frisar, desde já, que a história do neoliberalismo no Brasil tem como uma de suas principais marcas o ataque persistente aos fundamentos teóricos que orientaram a redação do texto constitucional (uma leitura de economia, política e sociedade bastante influenciada pela esquerda - aliás, não é por menos que o capitão do neoliberalismo por aqui pediu que esquecessem o que havia escrito, décadas atrás, em diálogo com tais correntes teóricas), o que resultou, sem dúvida, em grande obstáculo ideológico às necessárias lutas pela eficácia dos direitos sociais.

Nesse ambiente agressivamente contrário à visão social e desenvolvimentista da Constituição, o reconhecimento dos direitos dos trabalhadores, por exemplo, é objeto de severas contestações e ataques, nos mais diversos níveis, instituições e poderes. Seria possível dizer que a bandeira erguida pelos capitalistas brasileiros traz, desde então, o slogan "Todos os direitos, menos o do trabalho", ou seja, as relações de emprego passam a ser feitas por qualquer forma contratual (civil, entre pessoas físicas, ainda que a pessoa física seja nitidamente uma empresa; comercial, entre pessoas jurídicas, ainda que a pessoa jurídica seja um trabalhador individualmente dedicado) ou não contratual (prefere-se até o direito penal, como nos recorrentes casos do trabalho infantil e escravo!), desde que sobre elas não recaia o terrível manto da CLT! No plano da atuação coletiva dos trabalhadores, é exemplar para atestar os desafios da concretização da Constituição observar o direito de greve: ao contrário dos amplos termos com que vem previsto no texto constitucional ${ }^{103}$, seu destino é cada vez mais estreito ${ }^{104}$, em flagrante negação de seu sentido.

\footnotetext{
103 À época da Constituinte, Fábio Konder COMPARATO, no projeto de Constituição escrito a pedido do Partido dos Trabalhadores para orientar seus representantes, afirmava: "A garantia assegurada à liberdade sindical e à de greve - as quais se reforçam mutuamente - já dispensaria boa parte da regulação pública das relações de trabalho. Na verdade, a melhor proteção aos interesses dos trabalhadores é a autoproteção. Mas em país subdesenvolvido, marcado por fundas desigualdades de condições de vida, numa sociedade em que mais da metade da população vive em situação miserável, seria funestamente utópico dispensar a regulação pública das condições de trabalho" - Muda Brasil, p. 59.

104 "Em essência, a greve visa a bloquear, ainda que temporariamente, a atividade econômica, reduzindo os ganhos do empregador. Trata-se, pois, de uma forma de pressão, de coação, para se obter e manter melhores condições de vida. Embora o recurso à greve esteja inscrito como possibilidade objetiva na própria lógica contratual, sob a qual se dão as relações capitalistas de produção, foi necessário todo um calvário de lutas sociais e políticas dos trabalhadores para que a sociedade lhes reconhecesse esse direito.

No Brasil, tal reconhecimento em sua plenitude se deu apenas com a Constituição de 1988, cujo artigo 9o atribui a competência aos próprios trabalhadores para decidirem 'sobre a oportunidade do exercício do direito de greve', bem como sobre quais interesses pretendem assim defender.

Foi o resultado de um ascenso de lutas operárias a partir de 1978, de greves massivas e francamente 'ilegais', que não só pôs abaixo o regime jurídico que assim as considerava - a própria CLT e a Lei de Segurança Nacional - como também impulsionou decisivamente a redemocratização do país.
} 
Além dos ataques diretos aos direitos sociais, estudiosos da Constituição chamam atenção para a separação doutrinária e prática que foi feita entre constituição econômica (voltada a viabilizar os pactos sociais) e constituição financeira (voltada a viabilizar os pactos neoliberais), como se fossem duas partes autônomas da mesma Constituição, em que a primeira foi empurrada para a "agonia" e a segunda passou a ser aplicada "separada totalmente da ordem econômica e social, esterilizando, assim, a capacidade de intervenção do Estado na economia". ${ }^{105}$ Nas palavras de Alysson Leandro Mascaro:

\begin{abstract}
$\mathrm{Na}$ impossibilidade de uma mudança institucional ampla que legalize a investida neoliberal, a década de 1990 viveu o desconhecimento ou a burla da legalidade dos princípios constitucionais e dos direitos sociais como formas de estabilizar juridicamente novos preceitos econômicos. A política econômica neoliberal, assim, assenta-se na ilegalidade e na inconstitucionalidade, no desconhecimento ou na distorção da legalidade, como forma de consolidação institucional. ${ }^{106}$
\end{abstract}

\title{
3.2. Neoliberalismo e reestruturação produtiva
}

Concorrendo com os fatores políticos, econômicos e culturais que caracterizam a investida neoliberal, o trabalho sofre também internamente profundas transformações que visam adaptá-lo às exigências da "nova economia". Somar-se-á, então, aos ataques por meio da legislação e das instituições, uma forma ainda mais corrosiva de supressão dos

A década neoliberal - Porém, a reação do empresariado não tardou. Em 1989, o Congresso Nacional aprova a Lei de Greve (7.783), para regulamentar o exercício desse direito. Contudo, pretendia-se, na prática, limitálo. Sob pena de declaração de 'abuso de direito' e, portanto, de ilegalidade, a lei infraconstitucional retira dos trabalhadores a decisão sobre a oportunidade da realização de greve, ao estipular que a cessação coletiva do trabalho é facultada somente se 'frustrada a negociação'. Com esse requisito, vem a imposição de todo um ritual prévio de tratativas formais, observando-se prazos, publicação de editais em jornais e quórum em assembleias. Cria-se uma lista de 'serviços e atividades essenciais', cuja continuidade deve ser assegurada em nome das 'necessidades inadiáveis da comunidade'.

Por alguns anos, logo após a promulgação da Lei de Greve, houve uma intensa batalha política, ideológica e jurídica em torno de sua interpretação, aplicação concreta e, mesmo, sobre sua constitucionalidade. Algumas categorias mais fortes - leia-se, com maior capacidade de emperrar o circuito da produção e circulação econômicas - ignoravam abertamente as novas regras.

Num processo de medição de forças, com avanços e recuos, as políticas neoliberais de abertura comercial, privatização das empresas públicas e redução dos direitos sociais foram se impondo à medida que se quebrava a capacidade de resistência dos trabalhadores organizados. De um lado, silenciosamente, pelo crescimento do desemprego, que exerce uma pressão econômica difusa e contundente sobre aqueles cuja subsistência depende da venda da força de trabalho. E, de outro, pela repressão e neutralização dos movimentos do operariado. Tudo isso sob uma ofensiva ideológica nova, cuja hegemonia, para se ter uma ideia, chegou a lhe atrair o apelido de "pensamento único"" - Ricardo GEBRIM e Thiago BARISON, "As novas formas de repressão a greves”, pp. 131/136.

105 Gilberto BERCOVICI e Luís Fernando MASSONETTO, “A Constituição Dirigente Invertida: a blindagem da constituição financeira e a agonia da constituição econômica”, p. 129.

${ }^{106}$ Alysson Leandro MASCARO, Crítica da legalidade e do direito brasileiro, p. 185. 
direitos dos trabalhadores, disposta a sufocar a luta de classes dentro de cada local de trabalho ou, melhor ainda, dentro de cada trabalhador.

Neste sentido, José Luís Fiori, ao tratar das diferenças entre o velho liberalismo dos séculos XVIII e XIX e o neoliberalismo do final do século XX, afirma:

este novo liberalismo aparece como uma vitória ideológica que abre portas e legitima uma espécie de selvagem vingança do capital contra a política e contra os trabalhadores. Isto acontece porque essa vitória neoliberal se dá logo após uma época em que as políticas públicas e a luta dos trabalhadores conseguiram em conjunto construir uma das obras institucionais que eu reputaria das mais complexas e impressionantes que a humanidade conseguiu montar, e que foi chamado welfare state. E, portanto, é contra esta obra, sobretudo, que hoje se insurge o fundamentalismo liberal. E é ao projeto de desmonte desta obra igualitária que os neoliberais conseguiram transformar na grande bandeira das "reformas" das quais se fala indiferenciadamente em toda a América Latina, como se elas fossem o "abre-te sésamo" da felicidade ou de um "novo modelo de desenvolvimento". O que de fato deve ser considerado como uma vitória estrondosa do ponto de vista publicitário dos neoliberais, na medida em que se apossaram do "reformismo social-democrata", transformando-o numa arma ou proposta de destruição da principal obra dos social-democratas ${ }^{107}$

As décadas neoliberais ${ }^{108}$ têm sido, de fato, essa época de vingança - em parte tentada, em grande parte consumada - do capital contra os trabalhadores. Os trabalhadores brasileiros ${ }^{109}$ tiveram uma "vantagem" importante ao entrar neste combate, pois vinham da recente promulgação da Constituição (que ainda hoje impede o desmonte completo das normas inscritas na CLT), estavam reunidos numa central sindical forte (que logo em

\footnotetext{
107 José Luís FIORI, "Neoliberalismo e políticas públicas”, in Os moedeiros falsos, p. 215.

108 Sobre neoliberalismo, ver, em especial, o livro de David HARVEY, $O$ neoliberalismo: história e implicações. Para um estudo mais detalhado, do ponto de vista político-econômico, sobre a forma como o Plano Real se relaciona com as conjunturas nacionais e internacionais, em especial o neoliberalismo, ver Luiz FILGUEIRAS, História do Plano Real: fundamentos, impactos e contradições. Para a avaliação crítica da política econômica do primeiro mandato de Lula, ver Leda PAULANI, Brasil Delivery: servidão financeira e estado de emergência econômico. Com maior interesse para o mundo do trabalho no Brasil, ver também os artigos reunidos em Ricardo ANTUNES, A desertificação neoliberal no Brasil, e o livro de Armando BOITO JR., Politica neoliberal e sindicalismo no Brasil. Ver, ainda, de Leda Maria Paulani, "Capitalismo financeiro, estado de emergência econômico e hegemonia às avessas no Brasil”, in Francisco de OLIVEIRA, Cibele RIZEK e Ruy BRAGA (orgs.), Hegemonia às avessas, pp. 109/134.

${ }^{109}$ Segundo Mauro Luis IASI, a ofensiva neoliberal no Brasil depara-se com um quadro significativamente diverso: "não apenas a dinâmica da luta de classes havia imposto patamares de direitos e valores que passam a fazer parte da cultura da classe trabalhadora e da sociedade em geral, mas fundamentalmente pelo fato de que a ordem monopolista exigia um grau de gestão de uma superpopulação relativa que não podia prescindir de ações dirigidas às manifestações da chamada questão social" - "A crise do capital: a era da hipocrisia deliberada", p. 36. Outro aspecto importante destacado pelo autor é a forma nova como Estado e mercado passam a se relacionar: "Privatizar siderúrgicas, mineradoras, o controle energético, estradas, portos e outras para se dedicar à saúde, educação e previdência dos mais pobres, já que os menos pobres e os ricos deveriam ou buscar exclusivamente estes bens no mercado ou combinar os mínimos públicos com complementações privadas" - idem, p. 37. Ver, ainda, meu artigo: Tarso de MELO, "Neoliberalismo e reserva do possível".
} 
seguida é enfraquecida e cooptada) e tinham um partido em acelerado crescimento (que não demorou para mudar sua orientação inicial), mas ainda assim puderam sentir rapidamente os efeitos do neoliberalismo por outro caminho.

Como lhe era em parte adverso o combate na "esfera pública" (mudar as leis e a Constituição, por exemplo, são processos complexos), talvez isso explique a velocidade com que o neoliberalismo, na forma da reestruturação produtiva, avançou para dentro das fábricas e escritórios, a fim de promover seus interesses num campo em que a assimetria de forças é completamente favorável ao seu movimento. Como compensação pelos efeitos da crise enfrentada desde os anos 1970 e as transformações do capital internacional das décadas seguintes, os capitalistas passam a reorganizar as relações de trabalho de modo a amortecer os impactos das mudanças sobre si próprios. ${ }^{110}$

A estratégia começa, em regra, com a ameaça do desemprego e o argumento de que a desregulamentação da relação de emprego viabiliza a sua manutenção. Apenas com este passo, o discurso hegemônico dos últimos 20 anos coloca os trabalhadores em xeque, fragmentando a sua percepção e o seu pertencimento a uma classe social específica, e lançando-o na luta individual pela sobrevivência. O trabalhador assim situado não reivindica nada além do que a manutenção do seu emprego e aceita, inclusive, que as suas condições de trabalho sejam precarizadas. Se na história dos direitos sociais, como já dito, era o capitalista que se desfazia dos anéis para não perder os dedos, sob o neoliberalismo os trabalhadores - lançados uns contra os outros na competição pela continuidade do emprego - entregam anéis, dedos, tudo em troca do salário. Até a alma.

Como afirma David Harvey, “A preocupação neoliberal com o indivíduo põe em segundo plano toda preocupação democrática social com a igualdade, a democracia e as solidariedades sociais". ${ }^{111}$ É desse modo que se entende porque "o neoliberalismo se tornou hegemônico como modalidade de discurso e passou a afetar tão amplamente os modos de pensamento que se incorporou às maneiras cotidianas de muitas pessoas interpretarem, viverem e compreenderem o mundo". ${ }^{112}$

\footnotetext{
${ }^{110}$ Relevante o exemplo, neste ponto, da categoria dos bancários, conforme estudado por Nise Jinkings, "As formas contemporâneas de exploração do trabalho nos bancos", in Ricardo ANTUNES, Maria A. Moraes SILVA (orgs.), O avesso do trabalho, pp. 207/241, demonstrando como a adequação dos bancos à etapa do capitalismo em que instituições financeiras não-bancárias dominam o mercado internacional repercutiu diretamente na forma de organização do trabalho dentro de cada unidade bancária, dentro de cada agência.

${ }^{111}$ David HARVEY, $O$ neoliberalismo, p. 190.

${ }^{112}$ David HARVEY, $O$ neoliberalismo, p. 13. Leia-se também: "se é verdade que, hoje, porque deixado só na arena graças ao desmoronamento do chamado socialismo real, o capitalismo não mais precisa cultivar a aparência de progresso e civilização que lhe foi impressa em sua origem, podendo expressar sem pudor os imperativos a que de fato responde, não é menos verdade que, por isso mesmo, o fetiche se instala de modo
} 
No mundo do trabalho ${ }^{113}$, essa "mudança cultural" chegou sob as roupagens mais diversas e perversas, seja com o questionamento da própria noção de centralidade do trabalho ${ }^{114}$, seja com formas de "flexibilização" informal de direitos de acordo com os interesses dos capitalistas, seja com estratégias psicológicas de dominação adotadas no interior dos locais de trabalho ${ }^{115}$, todas elas resultando em precarização. ${ }^{116}$

Essa "nova era da precarização estrutural do trabalho", na virada do século XX para o XXI, é caracterizada por Ricardo Antunes nos seguintes termos:

Entre as distintas formas de flexibilização - em verdade, precarização - podemos destacar, por exemplo, a salarial, de horário, funcional ou organizativa. A flexibilização pode ser entendida como "liberdade da empresa" para desempregar trabalhadores; sem penalidades, quando a produção e as vendas diminuem; liberdade, sempre para a empresa, para reduzir o horário de trabalho ou de recorrer a mais horas de trabalho; possibilidade de pagar salários reais mais baixos do que a paridade de trabalho exige; possibilidade de subdividir a jornada de trabalho em dia e semana segundo as conveniências das empresas, mudando os horários e as características do trabalho (por turno, por escala, em tempo parcial, horário flexível etc.); dentre tantas outras formas de precarização da força de trabalho ${ }^{117}$

Este movimento vai se caracterizar, ainda, do ponto de vista da organização interna dos processos produtivos ${ }^{118}$, pela contínua influência do modelo toyotista que passa a influenciar e até substituir o padrão produtivo taylorista-fordista. Com a introdução do

ainda mais perverso. A assimilação inquestionada, pela sociedade como um todo, dos valores que põem e reafirmam o capital (eficiência, lucro, concorrência etc.), assimilação essa que encontra na mídia um de seus principais executores, possibilita, de maneira ainda mais eficaz que antes, que um modo historicamente determinado de vida se mostre como inequivocamente natural" - Leda Maria PAULANI, Modernidade e discurso econômico, p. 200.

${ }^{113} \mathrm{O}$ melhor retrato que temos do mundo do trabalho, do perfil atual da classe-que-vive-do-trabalho e de suas alternativas políticas está em Ricardo ANTUNES, Os sentidos do trabalho.

${ }^{114}$ Para uma visão panorâmica do debate sobre a centralidade do trabalho no capitalismo contemporâneo, com revisão das principais teses, ver José Henrique Carvalho ORGANISTA, $O$ debate sobre a centralidade do trabalho. Ver, também, Sérgio Alfredo Massen PRIEB, A redução do trabalho vivo e a tese do fim da centralidade do trabalho em Schaff e Gorz: uma crítica marxista.

${ }^{115}$ Ver, principalmente, de Christophe DEJOURS, A loucura do trabalho e A banalização da injustiça social, e de Danièle LINHART, A desmedida do capital.

116 Ver, em Ricardo ANTUNES (org.), Riqueza e miséria do trabalho no Brasil, em especial Ricardo Antunes, "A era da informatização e a época da informalização: riqueza e miséria do trabalho no Brasil", pp. 15/25, e István Mészáros, "Desemprego e precarização: um grande desafio para a esquerda", pp. 27/44.

${ }^{117}$ Ricardo Antunes, "Século XXI: nova era da precarização estrutural do trabalho?", in Ricardo ANTUNES, Ruy BRAGA (orgs.), Infoproletários, p. 234.

${ }_{118}$ Sobre processo de trabalho, ver o clássico estudo de Harry BRAVERMAN, Trabalho e capital monopolista: a degradação do trabalho no século XX. Uma explanação sintética das mudanças ocorridas na organização do trabalho fabril durante o século passado está em Geraldo Augusto PINTO, A organização do trabalho no século 20: taylorismo, fordismo e toyotismo. Sobre as formas de intensificação do trabalho, ver a pesquisa Sadi Dal ROSSO, Mais trabalho!: a intensificação do labor na sociedade contemporânea. 
modelo japonês de produção, a intenção é adaptar os fluxos da produção aos fluxos do consumo. Consequentemente, entre o mundo flexível da produção toyotista e o mundo volátil do consumo, o trabalhador com direitos “inflexíveis" (como os da lei brasileira) será um empecilho terrível, a ser contornado ou suprimido: "ponto essencial do toyotismo é que, para a efetiva flexibilização do aparato produtivo, é também imprescindível a flexibilização dos trabalhadores. Direitos flexíveis, de modo a dispor desta força de trabalho em função direta das necessidades do mercado consumidor". ${ }^{119}$

Um dos efeitos dessa nova etapa do trabalho, constituída por trabalhadores isolados em seus problemas individuais, recai sobre a sindicalização. Repare-se, entretanto, que este é um duplo movimento de ataque: desestímulo ao trabalhador quanto a ser sindicalizado e ataque aos sindicatos por diversos caminhos ${ }^{120}$. O resultado é que:

Os sindicatos e centrais sindicais, que estavam à beira de uma ação propositiva nacional, entraram num evidente movimento defensivo a partir dos anos de 1990. Também houve uma desaceleração na quantidade de greves, com maior dispersão e fragmentação da ação sindical. A classe trabalhadora sindicalizada, empurrada pelo contexto da crise do capital, dificilmente lutou por novas conquistas e direitos, agindo sobretudo na defesa dos direitos existentes, cada vez mais ameaçados pela desregulamentação promovida pela adaptação das empresas nacionais às políticas macroeconômicas e pela ofensiva governamental de cunho neoliberal. ${ }^{121}$

Para o sindicalismo brasileiro, assim, as políticas neoliberais significaram o bloqueio do movimento operário combativo (que tenta voltar a despontar) e a chegada de

\footnotetext{
${ }^{119}$ Ricardo ANTUNES, Adeus ao Trabalho?, p. 36.

${ }^{120}$ Para acompanhar as transformações vividas pelo sindicalismo brasileiro após a redemocratização, ver Waldemar ROSSI, William Jorge GERAB, Para entender os sindicatos no Brasil: uma visão classista; quanto aos principais ataques de "flexibilização" durante o governo FHC, ver pp. 74-78. Ainda sobre as transformações do sindicalismo nas últimas duas décadas, na sua expressão mais radicalmente neoliberal, ver Patrícia Vieira TRÓPIA, Força sindical: política e ideologia no sindicalismo brasileiro. Sobre a postura política da CUT durante o governo Lula, ver o artigo de Roberto Véras de Oliveira, "O sindicalismo e a questão democrática na história recente do Brasil: o que se pode esperar?", in Francisco de OLIVEIRA, Cibele S. RIZEK (orgs.), A era da indeterminação, pp. 49/69. Ver, ainda, na mesma obra, Leonardo Mello e Silva, "Trabalho e reestruturação produtiva: o desmanche de classe", pp. 71/100. Um estudo sobre a forma como a CUT incorpora em seu discurso a compatibilização com os interesses do capital está na dissertação de Nágela Aparecida BRANDÃO, Crise e reestruturação capitalista: manutenção ou construção de uma nova ideologia?: uma análise da Central Única dos Trabalhadores. Sobre o sindicalismo recente no Brasil, ver Giovanni Alves, "Trabalho e sindicalismo no Brasil dos anos 2000: dilemas da era neoliberal”, in Ricardo ANTUNES (org.), Riqueza e miséria do trabalho no Brasil, pp. 461/474. Sobre as alterações recentes da legislação trabalhista e os processos sócio-políticos correspondentes, ver Andréia GALVÃO, Neoliberalismo e reforma trabalhista no Brasil. Ver, por fim, Ricardo Lara, "Contribuições acerca dos desafios do movimento sindical diante da crise do capital”, in Edvânia LOURENÇO, Vera NAVARRO, Iris BERTANI, José F. S. SILVA, Raquel SANT'ANA (orgs.). O avesso do trabalho II, pp. 85/106.

${ }^{121}$ Ricardo Lara, "Contribuições acerca dos desafios do movimento sindical diante da crise do capital", in Edvânia LOURENÇO et allii (orgs.). O avesso do trabalho II, p. 90.
} 
um discurso "negocial", "sindicalismo cidadão"122, em que o sindicato leva mais em consideração os interesses do capitalista do que os do próprio trabalhador e, além disso, entende que aqueles interesses são ou mais importantes que estes ou convergentes. Não é de espantar, assim, que atualmente se possa ver "a perda de referibilidade da organização sindical como espaço para canalizar os movimentos reivindicatórios da classe trabalhadora e a incapacidade dos sindicatos de resignificar e reafirmar o processo social do trabalho no capitalismo" $" 123$. Some-se a isso, nos últimos anos, outro fator de peso:

\begin{abstract}
Transformações tecnológicas na área de produção e a política neoliberal, de redução do Estado e ataque aos direitos dos trabalhadores provocam divergências na definição de formas de enfrentamento desses problemas. A partir de 2003, sobretudo, essas divergências se somam às divergências relacionadas ao apoio ou à oposição ao governo Lula e seu plano de governo neoliberal. ${ }^{124}$
\end{abstract}

Destroçada em seus fundamentos, a classe trabalhadora passa a não se identificar mais consigo, de modo que a própria expressão "classe trabalhadora", junto com o esfacelamento concreto da classe, sofre um grave esvaziamento ${ }^{125}$. Os trabalhadores, mesmo aqueles mais diretamente atingidos pelos efeitos da neoliberalização, não consideram o caminho da política de classe para solucionar seus problemas. O que restou de luta operária está localizado nos setores em que havia maior formalização das relações e

\footnotetext{
${ }^{122}$ Ver Marcelo Badaró MATOS, Trabalhadores e sindicatos no Brasil. Interessante notar, entretanto, que o estudo de Patrícia Vieira TRÓPIA, Força sindical, conclui que os trabalhadores, sob forte campanha ideológica da Força Sindical, diante da encruzilhada "ou os direitos ou o emprego", acabavam concordando passivamente com as teses neoliberais. Contudo, a autora afirma que não se pode falar em adesão dos trabalhadores - mas apenas dos dirigentes sindicais - ao neoliberalismo (pp. 187/206).

123 Aldacy Rachid Coutinho, "Perfil da sindicalização no Brasil contemporâneo", in OLIVEIRA NETO, Francisco José Rodrigues de; COUTINHO, Jacinto Nelson Miranda; MEZZAROBA, Orides; BRANDÃO, Paulo de Tarso (orgs.), Constituição e Estado Social, p. 27.

${ }^{124}$ Waldemar ROSSI, William Jorge GERAB, Para entender os sindicatos no Brasil, p. 59.

125 “Os operários tendem assim a transformar-se num grupo 'objeto', progressivamente despossuído de seus instrumentos de luta e inspirando ora menosprezo, ora compaixão. As forças que os unem agora são negativas: o envelhecimento, o medo do desemprego e da desqualificação social. As velhas 'atitudes políticas' foram desqualificadas, assim como a linguagem política que chama para a 'classe'. Hoje, muitos operários se distanciam dos modos antigos e de certas formas de sociabilidade que sentem como arcaicas, e esforçam-se para destacar-se do que parece 'operário' demais. A reivindicação difusa para não serem excluídos de práticas e atividades sociais antes reservadas às outras classes corresponde, em especial, à profunda exigência de igualdade que anima um número crescente deles. Essa influência cada vez maior do modelo meritocrático é menos uma prova de seu aburguesamento do que a expressão de sua recusa em retomar por conta própria uma identidade social puramente operária - construída desde muito, mas desvalorizada - para impor uma imagem mais positiva de si mesmos. Se a constatação desse estilhaçamento da classe operária tem nuances de pesar e de nostalgia, não é porque obriga a pôr luto pela 'classe operária' aliás, é preciso dizer que sua elevação à categoria de mito, inclusive por certos sociólogos, foi durante muito tempo um obstáculo de peso à compreensão sociológica das transformações que afetavam o mundo operário -, mas porque mostra que a perenidade da cultura operária encontra-se fortemente ameaçada. Ora, é essa cultura antiga, profundamente politizada, construída por meio de lutas, que permitia conservar e afirmar um mínimo de autoestima" - Stéphane BEAUD, Michel PIALOUX, Retorno à condição operária, p. 298.
} 
maior sindicalização nos períodos imediatamente anteriores, de modo que havia algo a ser defendido, mas não algo a ser conquistado. As lutas mudaram:

Estudiosos do tema têm apontado que houve, no Brasil, além de uma alteração no padrão das greves nos anos 1990, mudanças nas reivindicações. As greves por categoria perderam importância para as paralisações por empresas. O predomínio de greves por empresa, e, consequentemente, a pulverização das negociações, foi acompanhado, no que diz respeito às reivindicações, de uma plataforma de negociações progressivamente defensiva. As reivindicações salariais, dominantes na década de 1980, mantiveram sua importância, sobretudo, durante o período inflacionário, mas, a partir de 1996, deixaram de ser a principal causa das greves brasileiras. Em vez de reivindicar reajuste e reposição salarial, o principal motivo das greves passou a ser o descumprimento de obrigações trabalhistas por parte do empresariado, o que levou os trabalhadores brasileiros a uma situação defensiva: lutar para manter direitos adquiridos ou acordados. ${ }^{126}$

Desnecessário dizer, então, que esta luta defensiva é fundamentalmente relacionada aos direitos dos trabalhadores ${ }^{127}$ : de um lado, a eles se agarram seus titulares; de outro, o capitalista cria ou ressuscita todo tipo de expediente para livrar-se deles. Se este é um embate por interesses imediatos, de parte a parte, que aparece como uma simples lide, para os trabalhadores, no entanto, que nele disputam, sob a forma de um interesse pontual, a sua própria sobrevivência, tal embate envolve dimensões diferentes da jurídica.

\subsection{Lutas cotidianas e conscientização de classe}

Quando Engels afirma, no seu estudo sobre os trabalhadores ingleses, que a greve é uma "escola de guerra" e que as associações operárias "contribuem notavelmente para alimentar o ódio e a revolta dos operários contra a classe proprietária"128, o que está em questão é, mais uma vez, o papel que as lutas imediatas dos trabalhadores têm para a formação da consciência de classe necessária à superação do capital.

\footnotetext{
${ }^{126}$ Patrícia Vieira TRÓPIA, Força sindical, pp.109/110.

127 Sobre os ataques diversos sofridos pelo Direito do Trabalho atualmente, ver José Damião de Lima Trindade, "Terá o Direito do Trabalho chegado a seu esgotamento histórico?", in SILVA, Alessandro; SOUTO MAIOR, Jorge L.; FELIPPE, Kenarik B.; SEMER, Marcelo (coords.), Direitos humanos - essência do direito do trabalho, pp. 49/63. No mesmo sentido, ver uma obra em que, significativamente, um grande número de juristas se dedicou a criticar, em decisões da mais alta corte da Justiça Trabalhista, os "modos ocultos de flexibilizar": COUTINHO, Grijalbo Fernandes; MELO FILHO, Hugo Cavalcanti; SOUTO MAIOR, Jorge Luiz; FAVA, Marcos Neves (coords.). $O$ mundo do trabalho: leituras críticas da jurisprudência do TST: em defesa do direito do trabalho. Vol. I. SP: LTr, 2009.

${ }^{128}$ Friedrich ENGELS, A situação da classe trabalhadora na Inglaterra, p. 259 e p. 254.
} 
Em todos esses momentos e em outros já citados, ressalta-se o papel central que a legislação desempenha nas lutas de classes. A lei - criá-la, cumpri-la, mantê-la - é instrumento de luta e, consequentemente, resulta em conscientização da classe operária a respeito de sua condição. Marx, a propósito, escreve: "Em 1852, quando L. Bonaparte procurou firmar sua posição junto à burguesia, mexendo na jornada legal de trabalho, o povo trabalhador francês gritou a uma só boca: 'A lei que reduz a jornada de trabalho a 12 horas é o único bem que nos restou da legislação da República" ${ }^{129}$

O que fica evidente é que tais lutas não podem ser separadas dos objetivos maiores de emancipação dos trabalhadores. Na Crítica do Programa de Gotha (1875), por exemplo, por mais que não alimente dúvidas sobre a necessidade de a luta operária ser internacional, Marx afirma: "É totalmente evidente que, para em geral poder lutar, a classe operária tem de se organizar, no seu país, como classe e que o interior [Inland] é a cena imediata da sua luta. Nesta medida, não pelo conteúdo, mas, como o Manifesto Comunista diz, 'pela forma', a luta de classes é para ele nacional". ${ }^{130}$

Destaque-se, com isso, que não é ingenuidade, conformismo, conservadorismo ou reformismo da classe trabalhadora lutar as lutas possíveis, dando à política o sentido em que Mészáros a definiu: “aplicação consciente de medidas estratégicas capazes de afetar profundamente o desenvolvimento social como um todo"131. Tais lutas são válidas tanto pelo seu sentido imediato quanto pela conscientização ${ }^{132}$ que propiciam, mas também porque tocam tendencialmente objetivos mais importantes do que aqueles que as motivaram num primeiro momento. Esta é a afirmação de Rosa Luxemburgo:

\begin{abstract}
Se para a burguesia a democracia tornou-se supérflua ou mesmo incômoda, é, ao contrário, necessária e indispensável à classe operária. É necessária em primeiro lugar porque cria formas políticas (administração autônoma, direito eleitoral etc.) que servirão de pontos de apoio ao proletariado em seu trabalho de transformação da sociedade burguesa. Em segundo lugar, é indispensável porque só por meio dela, na luta pela democracia, no exercício de seus direitos, pode o proletariado chegar à consciência de seus interesses de classe e suas tarefas históricas. ${ }^{133}$
\end{abstract}

\footnotetext{
${ }^{129}$ Karl MARX, O capital [col. Os Economistas], vol. I, t. 1, p. 219.

${ }^{130}$ Karl MARX, Friedrich ENGELS, Obras escolhidas, t. 3, p. 19.

${ }^{131}$ István MÉSZÁROS, Para além do capital, p. 1001.

${ }^{132}$ Ver István MÉSZÁROS, "Consciência de classe necessária e consciência de classe contingente”, in Filosofia, ideologia e ciência social, pp. 55/90. Sobre a problemática da consciência social na teoria sociológica, ver Mauro Luis IASI, $O$ dilema de Hamlet: o ser e o não ser da consciência. Ver, também, do autor, Ensaios sobre consciência e emancipação, em especial “Ideologia... quer uma para viver?”, pp. 77/87.

${ }^{133}$ Rosa LUXEMBURGO, Reforma ou revolução?, p. 101. No mesmo sentido: "Decisivo aqui é referir que a consciência é originada no interior da vida cotidiana. É na cotidianidade que as questões são suscitadas, e as
} 
Quase duzentos anos de disputas ao redor das leis ${ }^{134}$ não podem ser colocados na lata de lixo da história da classe operária, evidentemente. Tampouco se deve crer que a precarização - já em curso ou suas tendências, como bem expostas por Ricardo Antunes ${ }^{135}$ - será resolvida por lei, mas é relevante notar que, no caso brasileiro, ela tem sido em grande medida imposta por lei, seja com a alteração da legislação protetiva que lhe era contrária, seja com novidades legislativas que assegurem os empresários nos futuros processos trabalhistas ou enfrentamentos sindicais ${ }^{136}$. Consequentemente, se o direito é a ferramenta escolhida para a realização dessa tarefa, também deve ser disputado, pois "as pressões por desregulamentação têm impactos muito profundos em modelos legislados como o nosso, dado que a legislação, aqui mais que em outra parte, é constitutiva do que as classes sociais fizeram de si mesmas ao longo da história". ${ }^{137}$

Ainda que se trate, como afirma Ellen Wood, de uma luta de classes "domesticada" em cada fábrica, obrigada a se "encapsular no interior da unidade individual de produção"138, constrangida a reivindicações particularistas e "economicistas" ${ }^{139}$, o tipo de crise (ou de argumento) que atribui os problemas da empresa a uma dimensão nacional ou até transnacional é capaz de lançar aquelas reivindicações para um nível político tão amplo (nacional ou transnacional) quanto o das causas de seus problemas particulares. Como um

respostas dos indivíduos e das classes são uma constante busca de indagações que se originam na vida cotidiana, onde as questões lhes são afloradas" - Ricardo ANTUNES, Adeus ao Trabalho?, p. 119.

${ }^{134}$ Marx expõe precisamente (pra variar...) o cerne dessas lutas: "O capitalista afirma seu direito como comprador, quando procura prolongar o mais possível a jornada de trabalho e transformar onde for possível uma jornada de trabalho em duas. Por outro lado, a natureza específica da mercadoria vendida implica um limite de seu consumo pelo comprador, e o trabalhador afirma seu direito como vendedor, quando quer limitar a jornada de trabalho a determinada grandeza normal. Ocorre aqui, portanto, uma antinomia, direito comtra direito, ambos apoiados na lei do intercâmbio de mercadorias. Entre direitos iguais decide a força. E assim a regulamentação da jornada de trabalho apresenta-se na história da produção capitalista como uma luta ao redor dos limites da jornada de trabalho - uma luta entre o capitalista coletivo, isto é, a classe dos capitalistas, e o trabalhador coletivo, ou a classe trabalhadora" - O capital [col. Os Economistas], vol. I, t. 1, p. 190. Ou, ainda, nas palavras de Engels: "O operário sabe muitíssimo bem - porque aprendeu várias vezes, por experiência direta e própria - que a lei é um látego produzido pelo burguês; por isso, se não for obrigado, não a cumpre. [...] Uma vez que os operários não respeitam a lei, mas apenas reconhecem sua força enquanto eles mesmos não dispõem da força para mudá-la, é mais que natural que avancem propostas para modificálas, é mais que natural que, no lugar da lei burguesa, queiram instaurar uma lei proletária" - Friedrich ENGELS, A situação da classe trabalhadora na Inglaterra, pp. 261/262.

135 “Século XXI: nova era da precarização estrutural do trabalho?”, in Infoproletários, pp. 231/238.

${ }^{136}$ Ver o capítulo "Direito do trabalho e relações de classe no Brasil", in Adalberto Moreira CARDOSO, A década neoliberal e a crise dos sindicatos no Brasil, pp. 122/204, em que o autor identifica uma transição do momento de juridificação (leis) para o de judicialização (processos) nas relações trabalhistas.

${ }^{137}$ Adalberto Moreira CARDOSO, A década neoliberal e a crise dos sindicatos no Brasil, p. 122.

${ }^{138}$ Ellen Meiksins WOOD, Democracia contra capitalismo, p. 47.

${ }^{139}$ Ellen Meiksins WOOD, Democracia contra capitalismo, p. 49. 
efeito colateral da constatação de que a causa de seus problemas está bem acima do patrão, a luta para solucioná-los pode atingir, de fato, alvos bem superiores.

E isto não se dá casualmente, porque, mais uma vez citando Ellen Wood, "A luta de classes tem um potencial claro como força de transformação porque, quaisquer que sejam as motivações imediatas de qualquer conflito de classes, o terreno de luta está estrategicamente situado no coração da existência social". ${ }^{140}$

Mauro Iasi discute, no contexto da recente crise do capital, como se dá uma oposição entre os "interesses dos capitalistas" e os "interesses do capital", capaz de romper o véu de legitimação do capital como algo "natural”. Em suas palavras:

Ao quebrar-se a universalidade que unia as particularidades capitalistas, condição material para a hegemonia da burguesia, abre-se a possibilidade da classe trabalhadora apresentar seu próprio interesse em choque com a universalidade concreta/abstrata do capital, tornando possível um acirramento da luta de classes. No entanto, as coisas não são tão simples. Ao lado da possibilidade de intensificação da luta da classe trabalhadora que se vê jogada em condições de intensificação da exploração, desemprego, rebaixamento de salários e precarização das condições de vida, a crise atualiza de maneira muito enfática a possibilidade do pacto social.

A crise é, antes de tudo, o momento da chantagem do capital sobre o trabalho. ${ }^{141}$

Se há, de um lado, o risco da investida ainda mais violenta do capital, de outro existe a premência concreta dos trabalhadores a que atuem e se defendam, pois "é justamente a brutal intensificação do trabalho que desvela a contradição entre o discurso e a prática" $" 142$ e é capaz de remobilizar os trabalhadores na forma de uma "classe-que-vivedo-trabalho" ${ }^{143}$ e se identifica como tal na realidade. Em síntese, é o capital que, de tempos em tempos, coloca os trabalhadores no seu devido lugar de classe e, portanto, não os deixa

${ }^{140}$ Ellen Meiksins WOOD, Democracia contra capitalismo, p. 100.

${ }^{141}$ Mauro Luis IASI, “A crise do capital: a era da hipocrisia deliberada”, p. 31.

${ }^{142}$ Stéphane BEAUD, Michel PIALOUX, Retorno à condição operária, p. 183.

143 A expressão é de Ricardo Antunes. A propósito: "apesar da heterogeneização, complexificação e fragmentação da classe trabalhadora, as possibilidades de uma efetiva emancipação humana ainda podem encontrar concretude e viabilidade social a partir das revoltas e rebeliões que se originam centralmente (e não exclusivamente) no mundo do trabalho; um processo de emancipação simultaneamente do trabalho, no trabalho e pelo trabalho. Essa formulação não exclui nem suprime outras formas importantes de rebeldia e contestação. Mas, vivendo numa sociedade que produz mercadorias, valores de troca, as revoltas do trabalho acabam tendo estatuto de centralidade. Todo o amplo leque de assalariados que compreendem o setor de serviços, mais os trabalhadores 'terceirizados', os trabalhadores do mercado informal, os 'trabalhadores domésticos', os desempregados, os sub-empregados etc., podem somar-se aos trabalhadores diretamente produtivos, e, por isso, atuando como classe, constituírem-se no segmento social dotado de maior potencialidade anticapitalista" - Ricardo ANTUNES, O caracol e sua concha, p. 93. 
quietos. Se, inicialmente, tal confronto pode se dar de forma individual, espontânea ou "subterrânea"144, não se pode subestimar seu potencial combativo.

Somadas a outras lutas mais ou menos particularizadas, a rebeldia que começa no trabalho, ao acender a consciência de classe dos trabalhadores, mostra-lhes que é possível "resistir ao estranhamento enquanto preparamos a emancipação"145. Pode parecer simples aposta otimista, mas é, na verdade, questão de organização política:

As mudanças das relações de trabalho influem também na própria atividade de trabalho, na condição individual em que é colocado o trabalhador, determinando, assim, a sua consciência e a sua disponibilidade subjetiva para a rebeldia, em um âmbito de conflito de caráter local e territorial, mas, sobretudo, coletivo, e com a necessidade de uma ligação entre as diversas experiências do conflito de classe para a construção de uma identidade coletiva.

Nesse sentido, a luta pela renda social para todos(as) e para o alargamento global dos direitos do trabalho e da cidadania pode constituir um verdadeiro momento de identidade e de organização unificante do novo movimento operário, desde os trabalhadores empregados, passando pelos desempregados e chegando até os trabalhadores precarizados e aposentados; isso leva a uma unidade na luta dos sujeitos do trabalho, do não-trabalho e do trabalho negado, em um grande projeto de transformação social radical. ${ }^{146}$

Desta forma, por mais que todos esses fatores repousem sobre contradições profundas e sejam sempre uma "faca de dois gumes" na dominação do capital sobre o trabalho, pode-se crer que as lutas travadas no trabalho e por trabalho, se não podem ser vistas como a idealidade da luta política, reúnem os mais importantes elementos para o exercício de uma pressão legitimamente democrática em favor dos oprimidos. Nos momentos mais flagrantes de crise - em que o capital busca manter a taxa de lucro e, para tanto, dispara contra o trabalho suas "contratendências"147 - , é possível que as forças 144 Neste sentido, também, o interessante estudo de Marcia Hespanhol BERNARDO, Trabalho duro,
discurso flexível. Baseado em entrevistas com trabalhadores de "duas montadoras de automóveis de origem
japonesa com fábricas no Brasil" (cujos nomes não são citados...), investiga os efeitos da reestruturação
produtiva sobre a saúde dos trabalhadores, tendo em vista que algumas lesões tipicamente relacionadas à
pressão por produção atingem níveis quase epidêmicos. Em especial, chamo atenção para o capítulo final,
sobre as táticas de resistência dos trabalhadores - individuais e coletivas - contra a imposição das novas e
mais predatórias regras de organização do trabalho trazidas pelo "modelo japonês", "que vão da sabotagem à
manipulação das normas impostas, de modo a utilizá-las a seu favor" (p. 184) a outros atos cotidianos de
"antidisciplina". Em sentido semelhante, leia-se o estudo sobre formas "clandestinas" de contestação às
regras da organização do trabalho em Daniéle LINHART, Desmedida do capital, pp. 220/222.
145 Mauro Luis Iasi, "Trabalho: emancipação e estranhamento?", in Edvânia LOURENÇO, Vera
NAVARRO, Iris BERTANI, José F. S. SILVA, Raquel SANT'ANA (orgs.). O avesso do trabalho II, p. 82
146 Luciano VASAPOLLO, Por uma política de classe, p. 165.
147 Ver Karl MARX, O capital [col. Os Economistas], vol. III, t. 4, em especial pp. 177/178, sobre as "causas
contrariantes" disparadas contra a lei da queda tendencial da taxa de lucro, como a "elevação do grau de 
sociais anteriormente organizadas, ainda que até então em estado precário, ganhem maior coesão do ponto de vista organizativo e possam dar passos maiores. Se a crise, no jargão do capital, é "momento de oportunidades", também o é para os trabalhadores:

o papel que a classe trabalhadora desempenhará no momento de crise depende, em grande medida, de sua história, das lutas que se desenvolveram até o desencadear da crise, de sua capacidade de organização e formulação política, de tudo aquilo que Lênin denominou de condições subjetivas. Evidente que certos momentos conjunturais podem provocar movimentos de inflexão que alteram patamares políticos anteriormente conquistados, para o bem ou para o mal, de forma que uma classe pode atropelar suas antigas direções impulsionadas pelas condições objetivas produzidas pela crise, mas, também, pode abandonar posições mais avançadas buscando abrigo de miragens mais seguras no interior da ordem do capital. ${ }^{148}$

Não se desconsidere, de maneira alguma, a possibilidade de retrocesso nas conquistas trabalhistas, a infelizmente comum "perda de posições", mesmo em momentos menos críticos da reprodução do capital. Contudo, devidamente municiada do aparato democrático e consciente de seus interesses especificamente contrários aos do capital, os titulares dos direitos sociais podem multiplicar suas conquistas.

\subsection{Radicalização dos direitos sociais}

Tudo o que até aqui foi observado consiste na tentativa de demonstrar o potencial transformador que decorre da ambiguidade do direito, a fim de verificar as resistências a que tal ambiguidade dá ensejo e, como sementes, pensar sobre outras possíveis.

Por mais que o conjunto do que atualmente se chama de direitos sociais tenha sido aqui reduzido apenas às lutas propriamente operárias, cabe dizer que tais reflexões se pretendem válidas também para direitos que não são apenas aqueles previstos para o contrato de trabalho, tendo em vista que direitos como saúde, educação, moradia, entre outros, são marcados pela mesma ambiguidade e, assim, podem alimentar semelhantes resistências. O que faz com que os direitos dos trabalhadores mereçam destaque nesta investigação é o fato de que eles estão no centro da luta de classes da sociedade capitalista

exploração do trabalho" e a "compressão do salário abaixo de seu valor". Ver, ainda, Mauro Luis IASI, "A crise do capital: a era da hipocrisia deliberada", pp. 37/38, sobre o papel do Estado nesse processo.

${ }^{148}$ Mauro Luis IASI, “A crise do capital: a era da hipocrisia deliberada”, p. 32. 
e, assim, estão vinculados à produção social da existência, mas também porque têm às costas um longo histórico de lutas reais para sua conquista e manutenção.

Como diz Ricardo Antunes, "está na essência de toda luta econômica transformarse em luta política" ${ }^{149}$. E, aliás, assim já ensinava Karl Marx:

todo movimento em que a classe operária se apresenta como classe contrariamente às classes dominantes e procura impor-se por pressão exterior, é um movimento político. Por exemplo, a tentativa em uma fábrica particular ou ainda em uma indústria particular, de obrigar os capitalistas a estabelecerem uma jornada de trabalho menor, mediante greves etc., é um movimento puramente econômico. Ao contrário, o movimento que se dirige a conquistar uma Lei da jornada de oito horas etc., é um movimento político. E desta maneira, a partir dos distintos movimentos econômicos dos operários, cresce em toda parte um movimento político, quer dizer, um movimento da classe, que tem por objetivo impor seus interesses de forma geral, numa forma que possui uma força social de compulsão geral. $^{150}$

O fato de que a natureza das reivindicações dos trabalhadores, por estarem diretamente ligadas ao conflito que define a sociedade capitalista, guarde o potencial de converter uma luta dentro do sistema do capital por uma luta contra o sistema do capital, faz com que a classe operária possa iniciar seus confrontos maiores em espaços restritos, como forma de "partir do interior da vida cotidiana e intensificar as mutações e resistências que afloram nas manifestações de rebeldia e descontentamento dos seres sociais que vivem da venda de sua força de trabalho ou que estejam (temporariamente) excluídos desse processo pela lógica destrutiva que preside a sociedade contemporânea". ${ }^{151}$

O direito, como elemento essencial no âmbito cotidiano do trabalho, deve ser constantemente defendido, pressionado, utilizado, jamais subestimado. Nas palavras de David Harvey: "julgo uma decisão infeliz abandonar o campo dos direitos à hegemonia neoliberal. [...] Se a restauração de classe envolve a imposição de certo conjunto de direitos, a resistência a essa imposição envolve lutar em favor de direitos completamente diferentes dos daquele conjunto" ${ }^{, 152}$. Para Harvey, "Viver sob o neoliberalismo significa

\footnotetext{
${ }^{149}$ Ricardo ANTUNES, Classe operária, sindicatos e partido no Brasil, p. 129. Ver, a título de exemplo de lutas operárias com forte desdobramento político, o caso inglês estudado em Ricardo ANTUNES, Os sentidos do trabalho, pp. 40/45 e também pp. 90/95.

${ }^{150}$ Carta a Bolte, Londres, 23 de novembro de 1871, apud ANTUNES, A rebeldia do trabalho, p. 205.

${ }^{151}$ Ricardo ANTUNES, Os sentidos do trabalho, p. 247.

152 David HARVEY, O neoliberalismo, p. 193. O autor ainda afirma: "O sentido positivo de justiça como um direito, por exemplo, tem sido um forte estímulo para movimentos políticos: lutas contra injustiça têm animado com freqüência movimentos de mudança social. A inspiradora história dos movimentos dos direitos civis nos Estados Unidos é um exemplo disso" - idem, p. 193.
} 
também aceitar ou submeter-se a esse conjunto de direitos necessários à acumulação do capital". ${ }^{153}$ O enfrentamento desses direitos no uso que a eles pretende dar o capital é, consequentemente, enfrentamento do próprio capital, que, se costuma ser tímido, não se pode afirmar que necessariamente deva ser sempre assim.

Eric Hobsbawm, notável historiador marxista das lutas operárias, recorda que "as pessoas raramente exigem direitos, lutam por eles ou se preocupam com eles, a não ser que não os desfrutem suficientemente ou de nenhuma forma, ou, caso desfrutem deles, a não ser que sintam que esses direitos não estão seguros" ${ }^{\text {154 }}$. Poder-se-ia acrescentar: os direitos, mesmo precariamente realizados, ficam latentes à espera das lutas sociais.

Os direitos sociais ricamente gravados no texto constitucional - e quem lutou para que eles lá estivessem sabia muito bem o que estava fazendo! -, quando apropriados pelos grupos sociais cuja sobrevivência depende de sua concretização, certamente constituem significativo referencial para as lutas sociais: a configuração de uma relação de trabalho protegida pelas cláusulas precisas do texto constitucional baliza os movimentos defensivos ou propositivos da classe trabalhadora, que têm, assim, melhores condições de perceber quaisquer avanços que se processem contra suas conquistas.

Sabemos, com a lição de Jorge Luiz Souto Maior, que "O direito do trabalho [...] não resolve os problemas econômicos e sua base existencial, aliás, parte do pressuposto da existência de um modelo de produção capitalista. Se o modelo faliu não será o direito do trabalho que vai corrigi-lo e, por óbvio, não terá sido o direito do trabalho o culpado desta situação" ${ }^{155}$. Mas não se pode minimizar a contribuição que o direito do trabalho teve, durante o século XX no Brasil, para as lutas em que os trabalhadores estiveram envolvidos: por seus direitos, por novos direitos, para além de seus próprios direitos.

\footnotetext{
${ }^{153}$ David HARVEY, O neoliberalismo, p. 194.

${ }^{154}$ Eric J. HOBSBAWM, “O operariado e os direitos humanos", in Mundos do trabalho, p. 418.

155 Jorge Luiz SOUTO MAIOR, Relação de emprego \& Direito do Trabalho, p. 77. Interessante ainda, neste sentido, a reflexão do autor sobre a aplicabilidade do direito do trabalho diante do toyotismo: "esta realidade (desse 'novo paradigma' do processo produtivo) é incompatível com a aplicação do direito do trabalho? É evidente que não, aliás, muito pelo contrário, pois o direito do trabalho existe, exatamente, para inibir a exacerbação das formas de exploração do capital sobre o trabalho humano e o que se verifica é, exatamente, a intensificação da exploração, embora com as roupagens retóricas da 'colaboração' ou da 'parceria social'.

Assim, não há nenhum fundo de verdade na proposição de que o direito do trabalho, imaginado na perspectiva fordista, não tenha incidência no 'novo' mundo do trabalho. Primeiro, porque não há, como visto, propriamente, um novo modelo de produção, mas implementação de técnicas para fugir das amarras do direito social e para tornar menos nítida a exploração do capital sobre o trabalho (o que, no fundo, faz parte da própria história da humanidade); segundo, porque o direito do trabalho não tem sua essência ligada a um dado modelo de produção (para a incidência principiológica do direito do trabalho, a forma de exploração pouco importa) e, terceiro, é exatamente diante da busca desmesurada da exploração do capital sobre o trabalho humano que o direito do trabalho encontra, com muito mais razão, a lógica de sua existência" - idem, p. 43.
} 
No Brasil e no mundo, grande parte dos avanços sociais a que se pode assistir foi gerada como desdobramento das lutas econômicas e políticas iniciadas no mundo do trabalho. Mais que isso: é possível crer que a luta que se dá entre homem e máquina, entre força de trabalho e meio de produção, ao passo em que ataca duramente o cérebro e os músculos dos trabalhadores, pode ter como consequência que este mesmo trabalhador leve essa luta para fora da fábrica e enfrente, como força viva, as determinações que visam uma imposição unilateral. Se o maquinário - salvo em exceções confirmantes da regra e aspirações futuristas extremamente parciais - não pode viver sem sugar força do trabalho vivo, o trabalhador, por sua vez, não pode viver sem resistir à sua própria condição. Como dizem Stéphane Beaud e Michel Pialoux, em Retorno à condição operária:

Que futuro terá uma cultura operária privada de sua dimensão política? A última frase do livro de Georges Navel, ex-operário que se tornou escritor, diz: “Existe uma tristeza operária que só passa com a participação política”. Essas questões ultrapassam o quadro do mundo operário e interrogam o modo de recomposição da sociedade francesa como um todo, tamanha foi a importância do papel do movimento operário, por sua combatividade passada e pelas conquistas sociais que arrancaram das classes dominantes, na constituição e na consolidação de uma "sociedade salarial" que se estendeu à maioria da população ativa. É só pensar na aquisição e na consolidação dos direitos sociais: direito do trabalho, Previdência Social, direitos sindicais. ${ }^{156}$

Vale para França e, certamente, não é menos verdade para o Brasil, especialmente no que concerne aos centros industriais mais avançados. Onde mais ganhou terreno a transformação do trabalho em mercadoria, mais avançaram também as lutas para cercar o trabalho de "direitos do antivalor", na expressão de Francisco de Oliveira, direitos que põem às claras, em certa medida, as entranhas da relação capital-trabalho:

a expansão da produção capitalista tende a fortalecer o trabalho e, portanto, contrapõe o capital (e os Estados) a movimentos trabalhistas fortes. As concessões feitas para se controlar os movimentos, por sua vez, tendem a empurrar o sistema na direção de crises de lucratividade. Por outro, os esforços feitos pelo capital (e pelos Estados) para recompor os lucros invariavelmente envolvem a quebra de pactos sociais estabelecidos e a intensificação da mercadorização do trabalho, gerando, assim, crises de legitimidade e forte resistência.

Essas duas tendências - crises de lucratividade e crises de legitimidade - definem a tensão que há no bojo do capitalismo histórico. Certo tipo de crise só pode ser resolvido por meio de medidas que eventualmente resultem em outro tipo de crise. Essa alternância gera uma tendência à oscilação

${ }^{156}$ Stéphane BEAUD, Michel PIALOUX, Retorno à condição operária, p. 298. (grifos nossos) 
periódica entre fases históricas caracterizadas pelo movimento em direção à desmercadorização do trabalho, e pelo estabelecimento de novos pactos sociais, e fases caracterizadas pela remercantilização do trabalho e pelo rompimento de antigos pactos sociais. ${ }^{157}$

As lutas pelo direito do trabalho são, de fato, com este ou outro nome, lutas de “desmercadorização", ou ao menos lutas para deixar essa mercadoria - o trabalho - mais cara, não completamente (ou apenas parcialmente) sujeita à força bruta do capital sobre cada trabalhador. É óbvio que estamos ainda no jogo do capital, mas é igualmente óbvio que tais regras dão aos trabalhadores melhores condições de continuar jogando (de modo menos descartável) e, também, mais consciência a respeito do jogo.

O exemplo do trabalho, vale frisar novamente, pode ser multiplicado para outras lutas. Na lição de Ellen Wood, o princípio básico do capitalismo é isolar os indivíduos e deixá-los nus diante dos imperativos do mercado ${ }^{158}$. Como os direitos sociais são algo que se coloca entre os indivíduos e sua dependência do mercado, é por meio deles que se deve lutar pela "desmercadorização" (decommodification) e "desmercantilização" (demarketization) de tantas esferas da vida quantas sejam possíveis, ou seja, retirá-las da forma mercadoria e transformá-las em verdadeiros direitos sociais ${ }^{159}$, com a consequência que, agindo como a vanguarda das verdadeiras forças democráticas ${ }^{160}$, os trabalhadores fazem avançar o conjunto das oposições da democracia o capital.

Ora, mesmo que se possa objetar que há exagero em afirmar que, ao se tornarem direitos sociais, tais interesses vitais deixam de ser mercadoria, o fato é que restam mais transparentes as relações sociais do capital quando os grupos dominados inscrevem seus interesses em direitos, principalmente se esses direitos dizem respeito à troca essencial da sociedade sob o domínio do capital: força de trabalho por salário.

\footnotetext{
${ }^{157}$ Beverly J. SILVER, Forças do trabalho, p. 35.

158 "The basic principle of the capitalist system is the isolation of individuals and their naked exposure to market imperatives. It means eliminating everything that stands between people and dependence on the market, everything that makes them autonomous from the market. And when social life is driven by market imperatives, it's also subject to the cycles and crises of the market. For example, dispossessed workers, who depend on selling their labor-power for a wage, have nothing to fall back on when the market doesn't need them" - Ellen Meiksins WOOD, "Capitalism and social rights", s/n. [texto na internet]

159 "a constant struggle for decommodification, the de-marketization of as many spheres of life as posible. It means taking basic necessities like health care, housing and food and converting them from commodities produced for profit into truly social rights" - Ellen Meiksins WOOD, "Capitalism and social rights", s/n.

160 "State power can and should be used to convert human needs and public goods from commodities into social rights. This means that truly democratic forces, at local and national levels, both inside and outside the state, can make a real difference. They can push the state to pursue a program not only of social welfare but of decommodification and democratization. And that puts you, as social workers, in the front line of the democratic struggle" - Ellen Meiksins WOOD, "Capitalism and social rights", s/n.
} 
Se essa luta através dos direitos sociais - que é capaz de unir trabalhadores empregados e desempregados, bem como todos aqueles que dependam das políticas sociais de distribuição da riqueza - não se esgotar em si mesma, seu potencial será maior tanto para a conquista efetiva dos seus frutos imediatos quanto para a realização de outros objetivos, mais amplos e menos precários. Do contrário, separadas as guerrilhas e a guerra contra o capital, inclusive a colheita dos frutos imediatos será comprometida.

São diversos os exemplos históricos de que "A ausência de uma verdadeira teoria revolucionária que se fundisse com o movimento espontâneo de massas, permitindo com isso o alcance da totalidade, impediu que a classe operária se aproximasse da verdadeira consciência e acabou por manter sua ação em limites que não conseguiram superar a imediatidade"161. Portanto, se o caminho da "desmercadorização" possibilitado pelos direitos sociais é inevitável para a classe trabalhadora e toda a população carente, por ser a forma mais cotidiana de atendimento de suas necessidades prementes, tal percurso deve ser incessantemente alimentado por uma crítica de maior envergadura ao capital.

Conscientes das determinações do capital e sem abandonar jamais a perspectiva classista em sua crítica e em sua atuação, os trabalhadores terão instrumentos mais afiados de ataque e defesa de suas posições sob o domínio do capital, assegurando-se melhor pelos pedregosos e escorregadios caminhos rumo à emancipação social.

Falar em luta por direitos num momento em que se acusa sua "crise de eficácia" e até mesmo a "erosão do ordenamento jurídico"162, não resta dúvida, somente fará sentido

${ }^{161}$ Ricardo ANTUNES, Classe operária, sindicatos e partido no Brasil, p. 167. No mesmo sentido: "Sem a intervenção de uma ideologia abrangente, o potencial estratégico das mudanças mais ou menos extensivas que são espontaneamente postas em movimento em diferentes pontos do sistema social não pode ser articulado, pela falta de um ponto comum significativo que retenha e aumente cumulativamente a sua importância - que, isoladamente, é muito limitada. Como resultado, as mudanças particulares desprovidas de um quadro estratégico de referência (que apenas uma ideologia coerentemente definida pode proporcionar) em geral ficam limitadas à imediaticidade de seu impacto potencial estreitamente circunscrito" - István MÉSZÁROS, O poder da ideologia, p. 236. Ver, ainda, o ensaio "Desemprego e "precarização flexível"”, em o desafio e o fardo do tempo histórico, em que o filósofo húngaro debate a redução da semana de trabalho para 35 horas como "importante demanda estratégica", alertando, no entanto, que "o êxito duradouro nessa questão só é factível por meio de um intercâmbio sustentado - uma reciprocidade dialética - entre a luta pelo objetivo imediato de reduzir significativamente o tempo de trabalho e a transformação progressiva da ordem social estabelecida, que não pode deixar de resistir e anular todas essas demandas" (p. 141).

162 "A crise de eficácia é um ponto de comprometimento da própria existência e sobrevivência do contrato social, na medida em que a ausência ou inoperância prática das instituições conduz a um profundo abismo entre a legalidade e a faticidade das regras jurídicas. É deste abismo que se nutrem as desavenças sociais, os desvios, as condutas antijurídicas, os criminosos, para afrontarem ainda mais a própria existência dos organismos estatais e oficiais da representatividade popular. Na carência da eficácia da legislação, todo um novo arranjo de forças sociais se fortalece no sentido de criar um outro sentido para a vida social, que acaba tomando a conformação de um estado de natureza hobbesiano (lei do mais forte, leis de mercado, eticidades de grupos majoritários...)" - Eduardo C. B. BITTAR, O direito na pós-modernidade, p. 191. Sobre a "erosão do ordenamento jurídico", ver também Eduardo C. B. BITTAR, O direito na pós-modernidade, pp. 232/247. 
se esses direitos forem pensados como instrumentos de atuação política para além de sua utilização na satisfação das necessidades vitais imediatas. A radicalização dos direitos sociais que interessa aos trabalhadores vai justamente neste sentido.

Impõe-se, assim, como advoga Aton Fon Filho, uma luta para além dos direitos, uma vez "que eles somente se realizam se os agentes sociais logram atuar no plano da política, estabelecendo estratégias e táticas para o avanço, acrescendo as forças próprias e decrescendo as forças defensoras da desigualdade e da dominação". ${ }^{163}$ Se tal luta é para além dos direitos, não deixa, entretanto, de pressupor sua existência. Se o capital fez e faz o seu metabolismo sob as ambiguidades de sua expressão jurídica, a resistência contra o capital passa necessariamente pelo extravasamento de suas aparentes concessões.

Enfim, ao reconhecer "a especificidade do capitalismo como um [...] terreno político"164, reconhecemos também que "o capitalismo, com os obstáculos, fornece igualmente as únicas possibilidades de realizar o programa socialista"165.

\footnotetext{
163 Aton FON FILHO, "Dimensão política dos direitos humanos”, p. 104.

${ }^{164}$ Ellen Meiksins WOOD, Democracia contra capitalismo, p. 20.

${ }^{165}$ Rosa LUXEMBURGO, Reforma ou revolução?, p. 101.
} 


\section{CONSIDERAÇÕES FINAIS}

Na semana em que se conclui a redação desta tese, o noticiário trata de mais um ataque a tiros ocorrido nos Estados Unidos da América. Um universitário de 22 anos, munido de uma pistola automática, atingiu 20 pessoas durante um evento político, das quais pelo menos 6 morreram. Num primeiro momento, as notícias davam conta de que o atirador gostava de gramática e que sua lista de livros prediletos incluía Revolução dos bichos, O Mágico de Oz, Fábulas de Esopo, Odisseia, Alice no País das Maravilhas, Fahrenheit 451, Peter Pan, O sol é para todos, Um estranho no ninho, Pulp, Sidarta, O velho e o mar, As viagens de Gulliver, A República, Manifesto Comunista e Mein Kampf. Mas não demorou muito para que diversas matérias passassem a "selecionar" alguns títulos desta lista e afirmar que "o assassino revelava fascínio por ideologias extremas", pois "lia Marx e Hitler e tinha queimado a bandeira norte-americana".

Ideologias extremas de Marx e Hitler? Até que ponto esta afirmação, aparentemente inocente ou apenas apressada (como sói acontecer), que surge e rapidamente se dissemina pela mídia, pode revelar algo de importante sobre a "imagem pública" atribuída à crítica da economia política marxista e ao projeto político que dela se alimenta, a ponto de ser colocada lado a lado com as memórias e a doutrina do líder nazista? (Aliás, fica mais estranho ainda se considerarmos que um dos objetos da luta teórica e prática do Führer era o comunismo, tido como uma "ideia tão judaica quanto o capitalismo"...)

É provável que a frase apenas repita algo que se tornou comum nos mais diversos meios, dos mais aos menos ilustrados: tomar o marxismo, incluindo toda a obra de Marx e Engels, como sinônimo de estalinismo, negando-se a compreender o corte radicalmente emancipatório existente na obra dos autores do Manifesto Comunista em razão da experiência totalitária que se fez sob sua bandeira, cerca de meio século após a morte (física) dos pais do materialismo histórico. Daí para a associação com o nazismo, a fim de manchar completamente a reputação de Marx e Engels, é um pulinho...

Não é pouco, em termos ideológicos, que a imensa maioria das pessoas esteja de acordo quanto ao seguinte "princípio": o comunismo, como "errou", deve ser extinto - e com ele qualquer perspectiva classista de crítica e ataque ao capital; o capitalismo, que “erra” em proporções gritantes (e, mais que isso, nem mesmo se propõe a acertar...), deve ser consertado, regulado, equilibrado, sustentado, humanizado. 
Sem dúvida, é conveniente para o capital tomar o projeto socialista e comunista como definitivamente morto e enterrado sob as ruínas do muro do Berlim, sob os escombros da União Soviética, sob o sangue derramado pelos crimes cometidos nos regimes comunistas. Lamentável é que essa ladainha conforme também as mentes de quem dela não se beneficia, que compra inadvertidamente, dentro da embalagem do "livro negro do comunismo", o abandono dos projetos de transformação social profunda, que apenas podem subsistir sustentavelmente ${ }^{166}$ se afetarem a forma como se organiza a produção da vida sob o capital, não apenas os modos de vida superficialmente dados.

Se nenhum projeto político, por mais bem intencionado que seja, pode justificar a barbárie como parte de seus propósitos revolucionários, nem por isso as aspirações radicais da classe trabalhadora devem ser eternamente confundidas com tal barbárie e, de antemão, bloqueadas, como faz crer a associação entre Marx e Hitler. Se os trabalhadores, que são os únicos que têm a perder com o abandono de uma compreensão da sociedade capitalista como uma sociedade fundamentalmente de classes, incorporarem e naturalizarem o discurso neoliberal do "fim da história", sucumbirão ainda mais ao fetichismo.

Afirme-se claramente: não são todos iguais perante a lei, na mesma medida em que não estão todos igualmente postados na realidade. Trata-se aqui, para Hobsbawm, de partir “do pressuposto de que estamos todos de acordo quanto a uma proposição básica: que as classes sociais, o conflito de classes e a consciência de classe existem e desempenham um papel na história"167, sem desconsiderar, é claro, que grande parte de "quem tem a sorte de nascer no lugar certo nega que ainda existam as classes"168.

Os direitos dos trabalhadores, nesta guerra, acabam sendo uma espécie de bunker contra os ataques recorrentes do capital contra o trabalho quando historicamente situados e, certamente, podem servir como uma plataforma segura (tanto mais segura quanto mais o capital também do direito dependa para se impor) a partir da qual os trabalhadores, como classe, podem defender seus interesses no direito e para além do direito.

Sabe-se que "há uma distância astronômica entre a mera posse de direitos e sua efetiva implementação através de uma rede de práticas materialmente sustentadas e

\footnotetext{
${ }^{166}$ A propósito, esta palavra atualmente na moda faz lembrar que Stéphane BEAUD e Michel PIALOUX, em Retorno à condição operária, chamam a atenção para um sintoma do desgaste sofrido pela perspectiva política classista: o sucesso do Partido Verde entre os jovens operários franceses, mesmo aqueles que têm mais motivos de descontentamento com suas condições de trabalho (p. 299). Impossível não lembrar que, nas últimas eleições presidenciais brasileiras, algo muito parecido ocorreu: a fim de negar dois "partidos da ordem", os votos migraram para uma proposta "verde", não para uma proposta efetivamente "vermelha"...

${ }^{167}$ Eric J. HOBSBAWM, "Notas sobre consciência de classe", in Mundos do trabalho, p. 33.

${ }^{168}$ Luciano CANFORA, Crítica da retórica democrática, p. 110.
} 
socialmente viáveis de satisfação humana"169 - e é por esta razão que se deve insistir na luta pela constituição concreta dessas práticas e de outras necessárias.

O que permite acreditar que seja possível ainda persistir nessa luta, mesmo em tempos tão adversos, é justamente o fato de que o capital, que não vive sem sugar a riqueza do trabalho, produz permanentemente novas formas de ataque aos trabalhadores, a fim de contornar as crises que seu próprio desenvolvimento gera. Ao fazê-lo, obriga os trabalhadores a decidirem: ou aceitam novos rebaixamentos, enquanto podem, ou se levantam e lutam. No momento em que esses levantes não dependam mais dos ataques imediatos do capital e, muito mais que simples defesas, sejam eles mesmos os ataques, é provável que o tipo de arranjo social sobre o qual o capital se sustenta esteja severamente comprometido e possa ser reinventado, para um lado ou para outro. Neste momento, todas as possibilidades se abrirão a quem para elas estiver preparado.

A história, enfim, não terminou. Para Marx, ela nem mesmo começou. Enquanto isso, o capitalismo - que, em parte, escondeu suas vestes neoliberais para saltar sobre a crise recente - não permite, com a mercadorização de tudo quanto existe, o otimismo de quem pretenda ver um outro mundo surgir. Ao contrário, exige a militância oposta ${ }^{170}$, cada vez mais potente e objetiva, cada vez mais consciente de sua posição e convencida de que o capital, sob a face "humana" que aqui e ali oferece (responsabilidade social, ambiental etc.), não se dobrará contra seus próprios impulsos destrutivos.

Se pode haver otimismo no capitalismo, não pode ser na conversão do capitalismo em algo que nega o seu movimento necessariamente desigual, assimétrico e, no limite, injusto. $\mathrm{O}$ otimismo apenas pode residir para além do capital.

Se o direito, em cujo universo tão pouco se fala em transformação social (mesmo na interpretação de normas que têm fundamentalmente essa orientação), pode de alguma forma contribuir para a superação do capital, é com a radicalização de suas contradições: ao cobrar aquilo que o capital, por meio do direito, promete e não pode entregar, o coro dos descontentes pode obrigar o capital a trocar seu manto jurídico por outro. E talvez então, desfeito de sua principal feição ideológica, ele fique nu. E vulnerável.

\footnotetext{
${ }^{169}$ István MÉSZÁROS, O poder da ideologia, p.122.

170 "O tema que me impulsionou nesses quase 20 anos de estudo foi o da consciência, mais precisamente do movimento da formação da consciência e da possibilidade de rompimento com as amarras que prendem nossas mentes à reprodução da ordem que nos conforma. Cada militante que encontrei em todos esses anos foi, para mim, a prova viva de que é possível mudar o mundo, que a sociedade capitalista continua produzindo seus coveiros nos quais brotam sempre renovados os germes de uma nova consciência" - Mauro Luis IASI, As metamorfoses da consciência de classe, p. 16.
} 


\title{
ANEXO \\ UMA REFLEXÃO SOBRE MARXISMO E DIREITOS HUMANOS ${ }^{171}$
}

Discuto aqui aspectos atuais da relação entre marxismo e direitos humanos, aproveitando o ensejo das polêmicas que cercam o terceiro Programa Nacional de Direitos Humanos, apresentado como "opção definitiva pelo fortalecimento da democracia"172, ressaltando ainda que o PNDH-3 alega promover "Não apenas democracia política e institucional, grande anseio popular que a Constituição de 1988 já materializou, mas democracia também no que diz respeito à igualdade econômica e social". De início, devo dizer que o presente artigo foi escrito por alguém que compartilha da opinião de Ellen Meiksins Wood, em obra que, aliás, será referência constante nos argumentos que se seguirão aqui. A opinião a que me refiro está assim expressa:

\begin{abstract}
O capitalismo é estruturalmente antitético à democracia não somente pela razão óbvia de que nunca houve uma sociedade capitalista em que a riqueza não tivesse acesso privilegiado ao poder, mas também, e principalmente, porque a condição insuperável de existência do capitalismo é o fato de a mais básica das condições de vida, as exigências mais básicas de reprodução social, ter de se submeter aos ditames da acumulação de capital e às "leis" do mercado. Isso quer dizer que o capitalismo coloca necessariamente mais e mais esferas da vida fora do alcance da responsabilidade democrática. Toda prática humana que é transformada em mercadoria deixa de ser acessível ao poder democrático. Isso significa que a democratização deve seguir pari passu com a “destransformação em mercadoria”. Mas tal destransformação significa o fimm do capitalismo. ${ }^{173}$
\end{abstract}

É indispensável começar com uma longa advertência que esclareça que estas reflexões sobre direitos humanos levam em consideração que o ideal seria não precisar de direitos humanos, ou seja, que tais direitos são compreendidos e mesmo defendidos dentro das limitações próprias de sua vinculação histórica ao modo de produção capitalista, sob a sombra cada vez mais densa da superação deste modo de produção específico. Em outras palavras, a questão central aqui poderia ser formulada da seguinte maneira: qual o sentido

\footnotetext{
${ }^{171}$ Incluo este artigo - inédito - como anexo da tese a fim de demonstrar como a reflexão desenvolvida durante a pesquisa tende a se espraiar para o diálogo do marxismo com outras questões jurídicas e sociais contemporâneas, todas elas ligadas à transformação social.

172 Pres. Luiz Inácio Lula da Silva, “Apresentação”, in Programa Nacional de Direitos Humanos - PNDH-3, Brasília: SEDH/PR, 2010, p. 11.

${ }^{173}$ Ellen Meiksins Wood, Democracia contra capitalismo: a renovação do materialismo histórico. Trad. Paulo Cezar Castanheira. SP: Boitempo, 2003, p. 8.
} 
da defesa dos direitos humanos junto à defesa do socialismo como alternativa concreta rumo à emancipação humana? Ou ainda: como devem se comportar os socialistas diante dos direitos humanos enquanto o socialismo não vem?

Num primeiro passo, deve-se lembrar que este não é, de modo algum, um debate novo entre os marxistas: ele começa já com o próprio Marx, atravessa todo o enfrentamento político do final do século XIX até as revoluções do século XX e ganha especial destaque com os regimes políticos que - sob a bandeira do marxismo, mas longe das lições de Marx (o que se convencionou chamar de "socialismo real") - pisotearam todo o rol de garantias fundamentais que normalmente são encontradas junto à rubrica dos direitos humanos. Noutro passo, para ter a exata dimensão deste debate devemos lembrar que a defesa dos direitos humanos está intrinsecamente ligada à expansão das mais variadas noções de democracia e, por esta razão, tais expressões - "direitos humanos" e "democracia" - são praticamente sinônimas neste contexto, o que se dá da mesma forma no PNDH-3, que tem a maior parte dos seus eixos, diretrizes e objetivos estratégicos cruzados pelo verbo "democratizar" e outros que de alguma maneira o traduzem.

Um primeiro aspecto importante a ressaltar na relação entre marxismo e direitos humanos - tentando responder à pergunta formulada acima - é que, nos principais textos marxistas sobre o tema, desde aqueles assinados por Marx, os direitos humanos (e a democracia) são considerados não como garantias universais e eternas, mas sempre numa perspectiva estritamente política, de estratégia interna ao capitalismo, isto é, como mecanismos de resistência ao capitalismo. Não são pensados, portanto, como parte do que se chama de "teoria da transição", mas mais precisamente como parte das medidas de sobrevivência indispensáveis durante o capitalismo.

Acredito que se colocam neste sentido as afirmações de Marx em Salário, Preço e Lucro - já tantas vezes citadas - quanto à classe operária ter de considerar a importância dos "conflitos diários", das "lutas de guerrilhas" como "possibilidades [...] de melhorar em parte a sua situação", evitando que seja "transformada numa massa informe de homens famintos e arrasados, sem probabilidade de salvação", sem esquecer, contudo, que as conquistas nos "conflitos diários" contra os capitalistas são apenas "paliativos", incapazes de "cura[r] a enfermidade" e que servem "para retardar o movimento descendente, mas não para mudar sua direção" 174 .

${ }^{174}$ K. Marx, Trabalho Assalariado e Capital \& Salário, Preço e Lucro. SP: Expressão Popular, 2006, p. 141. 
Militam na mesma estratégia política as recomendações encontradas na "Mensagem do Comitê Central à Liga dos Comunistas" (1850) e também na introdução escrita por Engels, já às portas do século XX (em 1895), para A luta de classes na França, em que os instrumentos burgueses (especificamente, as disputas eleitorais na Alemanha do último quarto do século XIX) são considerados como possibilidade de "abrir brechas" favoráveis ao proletariado quando a luta de trincheiras, barricadas e baionetas tornou-se completamente desfavorável.

Fica claro, até aqui, que a defesa dos direitos humanos por um marxista está circunscrita a este caráter paliativo e desafiador que a luta por melhorias pontuais da condição de vida dos trabalhadores (que, aqui, simbolizam toda a parcela dominada da sociedade) consegue assumir no contexto completamente adverso da reprodução ampliada do capital.

Quanto ao caráter paliativo, basta dizer que a chamada "afirmação histórica dos direitos humanos" jamais esteve na contramão do desenvolvimento das sociedades capitalistas, mas apenas descreve um movimento permanente de incorporação de medidas que visam reduzir os efeitos sociais próprios deste desenvolvimento, dentro de uma lógica muito mais corretiva do que de oposição ao capitalismo, correlatas às medidas de regulação econômica que tentam corrigir - e salvar - o capitalismo sem barrar o seu funcionamento, a sua reprodução.

Neste ponto, é relevante também notar que, quando falamos aqui em radicalização da democracia, ou em radicalização dos direitos humanos, não podemos deixar de lado a constatação de que a radicalização do capitalismo dependeu sempre e ainda depende de sua face humanitária, da capacidade de apresentar como interesses e características gerais aqueles que são seus interesses e características mais particulares. Se se costuma dizer, desde Marx, que "a democracia é o caminho para o socialismo", nem por isso deixou de ser o veículo ideológico do mais antidemocrático capitalismo. Podemos reportar ao exemplo norte-americano - não apenas à ocupação do Iraque pelas tropas de Bush, mas ao papel que as organizações não-governamentais, sob a bandeira da democracia e causas humanitárias, com farto patrocínio da Casa Branca, tiveram na padronização das mais variadas sociedades segundo os interesses mercantis americanos, como têm demonstrado diversos autores, entre os quais destaco Makau wa Mutua ${ }^{175}$.

175 "The ideology of human rights", in Virginia Journal of International Law, v. 36, n. 3, Spring 1996, pp. 589-657. 
No entanto, quanto ao caráter desafiador da democracia e dos direitos humanos, pode-se arriscar uma outra aproximação com a citada introdução de Engels. A reação violenta suscitada pelo PNDH-3 é prova de como os instrumentos previstos no programa incomodam - ou podem incomodar, em razão de acender a reivindicação social - os interesses da classe dominante, que se apressa em calar as reivindicações - que logo são declaradas antidemocráticas! - e barrar qualquer possibilidade de efetivação daqueles instrumentos. Não é exagero aqui lembrar que, segundo Engels, diante do empenho do proletariado na utilização dos mecanismos de democracia formal, "a burguesia e o governo chegaram a ter mais medo da atuação legal que da atuação ilegal do partido operário, mais temor aos êxitos das eleições que aos êxitos da rebelião"176.

Já se pode arriscar, a esta altura, uma conclusão parcial: os direitos humanos serão paliativos mais eficientes quanto mais for explorado seu caráter desafiador. E, por força da conclusão parcial, estaremos diante de questões que vêm sendo formuladas desde Marx e Engels até nossos contemporâneos, como Ellen Wood, no livro citado, e István Mészáros, em vários artigos. São elas: por que insistir nos "paliativos”? Qual o sentido deles na luta pela superação do capitalismo rumo ao socialismo? Como ampliar os desafios que os direitos humanos podem oferecer ao capitalismo? Quais os limites desses desafios? E estas são apenas algumas das perguntas que os marxistas têm enfrentado, com fundamento nas obras de Marx, mas levando em consideração eventos históricos que o autor d'O Capital não assistiu.

István Mészáros, a propósito, é o autor de um estudo brilhante em que a relação entre marxismo e direitos humanos é devidamente investigada em textos de Marx, com o intuito de desfazer os equívocos sobre a rejeição de Marx aos "direitos do homem". Mészáros demonstra, neste sentido, que Marx não critica os direitos humanos "enquanto tais", mas como "racionalizações pré-fabricadas das estruturas predominantes de desigualdade e dominação":

Os direitos humanos de "liberdade", "fraternidade" e "igualdade" são, portanto, problemáticos, de acordo com Marx, não por si próprios, mas em função do contexto em que se originam, enquanto postulados ideais abstratos e irrealizáveis, contrapostos à realidade desconcertante da sociedade de indivíduos egoístas. Ou seja, uma sociedade regida pelas forças desumanas da competição

\footnotetext{
${ }^{176}$ Friedrich Engels, "Introdução", As lutas de classe na França de 1848 a 1850, in Karl Marx e Friedrich
} Engels, Textos, vol. 3, SP: Edições Sociais, s/d, p. 103. 
antagônica e do ganho implacável, aliados à concentração de riqueza e poder em um número cada vez menor de mãos. ${ }^{177}$

Contudo, Mészáros frisa que é incorreto, a partir dessa crítica, concluir mecanicamente que Marx rejeita os direitos humanos como uma simples ilusão, como uma promessa para não ser cumprida. Por mais que seja inegável o caráter ideológico dos direitos humanos, Mészáros aponta que a compreensão do papel dos direitos humanos em perspectiva marxista deve ser buscada na reflexão de Marx sobre a relação entre base econômica e superestrutura jurídica e política, com especial atenção para a "autonomia relativa" da superestrutura e das correspondentes formas de consciência social. Especial atenção porque, dentro do próprio marxismo, é muito comum reduzir a relação referida por Marx a uma "via de mão única", a uma determinação completa e unilateral de todos os elementos superestruturais pela base econômica da sociedade.

A partir da leitura de Marx, Mészáros demonstra as "complexas interações dialéticas" da relação entre base e superestrutura, com o intuito de revelar que a citada "autonomia relativa" e o "papel ativo" da superestrutura são essenciais para cimentar o próprio sistema de dominação do capital sobre a sociedade, decorrendo daí que direito e política não podem reproduzir identicamente as contradições da base econômica, sob pena de "a auto-legitimação dessa sociedade [ser] minada radicalmente e seu caráter de classe [ser] rapidamente desmascarado, através de seu fracasso em se manter como sistema correspondente às necessidades dos direitos humanos elementares"178. Noutra passagem, aliás, a explicitação daquelas interações é ainda mais precisa: "A produção de ideias para além das restrições institucionais imediatas da superestrutura legal e política age como um propulsor poderoso sobre a superstrutura, que, por sua vez, afeta dinamicamente as funções materiais da vida social. Sem ela, as realidades de classe se afirmariam automaticamente como uma determinação férrea, destruindo os próprios conceitos de lei e de política" ${ }^{\text {"179 }}$.

Obviamente, se podemos flagrar aí, mais uma vez, a natureza capitalista dos direitos humanos, também fica evidente que esses mesmos direitos são um importante campo de luta contra o capitalismo, justamente por conta da importância que tais direitos têm para a legitimação ideológica do sistema de dominação necessário à reprodução do

\footnotetext{
177 "Marxismo e direitos humanos", in Filosofia, ideologia e ciência social. Trad. Ester Vaisman. SP: Boitempo, 2008, p. 161.

${ }^{178}$ Idem, p. 165.

${ }^{179}$ Idem, p. 164.
} 
capital. Noutras palavras, é exatamente em razão de serem fundamentais para a reprodução do capitalismo que os direitos humanos são fundamentais para a luta contra o capital.

É o que constata, por exemplo, David Harvey quando afirma que o neoliberalismo e o neoconservadorismo norte-americanos são profundamente antidemocráticos e autoritários, devendo ser combatidos justamente com reivindicações democráticas. Segundo Harvey, "O déficit de democracia em países nominalmente 'democráticos' como os Estados Unidos é hoje imenso" 180 - ainda que este "hoje" se refira à era Bush, não me parece que tal afirmação tenha perdido sentido nos últimos anos. Podemos concluir, neste sentido, que a dependência profunda que o capitalismo tem, a um só tempo, de um discurso democrático e de uma prática antidemocrática, torna este sistema econômico parcial mas permanentemente vulnerável à contestação por meio dos próprios instrumentos democráticos, bem como a alternativas que possam surgir deles.

Ellen Wood explica que as relações sociais específicas do capitalismo "resultaram tanto no avanço da democracia quanto na sua estrita inibição, e o maior desafio ao capitalismo seria a extensão da democracia além de seus atuais limites extremamente reduzidos. É nesse ponto que 'democracia' se torna sinônimo de socialismo"181. Se considerarmos esta frase junto à afirmação, da mesma autora, de que "um capitalismo humano, 'social' e verdadeiramente democrático e igualitário é mais irreal e utópico que o socialismo" ${ }^{\# 2}$, temos, então, uma resposta inicial para as questões aqui formuladas: o sentido da luta pelos direitos humanos é tornar e manter visível a tensão contraditória entre capitalismo e democracia, denunciando as limitações democráticas sobre as quais se sustenta a reprodução do capital e "afiando" alternativas concretas para sua superação.

Os ataques sofridos pelo PNDH-3 - que, a rigor, apenas detalha instrumentos de efetivação para grande parte dos direitos que já se encontram na Constituição de 1988 são atestados da importância das reivindicações democráticas. Do ponto de vista da classe dominante, são ameaças concretas à reprodução do sistema de que ela se beneficia. A "radicalização" que o PNDH-3 abrigou parece ter tocado em feridas abertas da sociedade brasileira e, assim, deveria redimensionar o debate, dentro da própria esquerda, sobre o papel que os direitos humanos podem exercer enquanto o socialismo não vem.

\footnotetext{
${ }^{180}$ O neoliberalismo: história e implicações. Trad. Adail Sobral, Maria Stela Gonçalves. SP: Loyola, 2008, p. 219.

${ }^{181}$ Ellen Meiksins Wood, ob. cit., p. 23.

${ }^{182}$ Idem, p. 250.
} 
Não faz muito tempo, o italiano Luciano Canfora, historiador da democracia ${ }^{183}$, anotou - numa obra curta e contundente - o desafio enfrentado pela esquerda para defender sua perspectiva política sem sucumbir à "cultura de seus adversários", num contexto em que aquilo que orientaria a ação da esquerda estava completamente incorporado pelo discurso da direita. No livro, que não por acaso traz o título Crítica da retórica democrática, Canfora afirma:

\begin{abstract}
Se quiser sobreviver, a esquerda deverá transformar-se no epicentro de um vasto agrupamento que tenha como eixo valores diametralmente opostos àqueles defendidos e praticados pela direita. Nessa façanha do nosso presente, os aliados de uma esquerda com idéias claras poderiam ser inúmeros, provenientes dos mais diferentes credos e das mais diversas camadas. Se, ao contrário, prevalecer a idéia de que os portadores dos valores opostos devam ser seguidos e imitados em seu próprio terreno, a partida estará perdida. ${ }^{184}$
\end{abstract}

Parece-me, contudo, que o exemplo do PNDH-3 colocou cores diferentes neste quadro: quando grande parte da sociedade brasileira, reunida em diversas associações e instituições, incluindo uma Secretaria Especial da Presidência da República, toma os direitos humanos como campo de luta e propõe sua ampliação e efetivação, é a direita que se sente obrigada a abandonar o discurso democrático - chegando a propor, de modo nada sutil, que o PNDH-3 fosse queimado junto com seus autores! $!^{185}$ - e demarcar mais explicitamente seus interesses, neste ato definindo, por oposição, como seus adversários todos aqueles que defendam os direitos humanos.

Colocados diante desta realidade, que faz lembrar a passagem do Manifesto comunista em que Marx e Engels afirmam que a burguesia “é incapaz de dominar [por muito tempo], pois é incapaz de assegurar a seu escravo a própria existência no âmbito da escravidão", é fácil perceber que, por mais que persista, no amplo espectro da esquerda, a encruzilhada dilemática entre defender a democracia e os direitos humanos para além de suas próprias forças ou rejeitá-los completamente em razão do seu vício de origem, tal disputa não pode nublar a necessidade e oportunidade da defesa dos direitos humanos em meio à voracidade destrutiva da dominação capitalista. Nas palavras de Mészáros:

\footnotetext{
${ }^{183}$ Refiro-me a A Democracia: História de uma Ideologia. Trad. José Jacinto Correia Serra. Lisboa: Edições $70,2007$.

${ }^{184}$ Luciano Canfora, Crítica da retórica democrática. Trad. Valéria Silva. SP: Estação Liberdade, 2007, p. 36.

${ }^{185}$ Refiro-me a artigo de Ives Gandra da Silva Martins, "Guerrilha e redemocratização", publicado no jornal Folha de S. Paulo em 22 de janeiro de 2010.
} 
“enquanto estivermos onde estamos, e enquanto o 'livre desenvolvimento das individualidades' estiver tão distante de nós como está, a realização dos direitos humanos é e permanece uma questão de alta relevância para todos os socialistas"186

À guisa de conclusão provisória, devemos lembrar de um outro italiano (outro Luciano), o intelectual e militante político Luciano Vasapollo, que definiu com precisão - e não sem algum otimismo - o papel político que a luta interna ao capitalismo pode alcançar:

Enquanto se reivindicam maiores direitos, melhores salários diretos, indiretos e deferidos, maior democracia, se constrói ao mesmo tempo a subjetividade político-social que é capaz de conquistar consciência no terreno da superação do capitalismo, para a construção de uma nova formação social, que desenvolva relações no interior do horizonte do socialismo ${ }^{187}$.

De minha parte - e de olho na experiência, por exemplo, dos movimentos de luta pela reforma agrária - acredito que esta construção da subjetividade político-social no âmbito das reivindicações de direitos é mais rápida, consistente e afiada quando a luta se depara com "nãos", do que quando os direitos são, de fato, atendidos. E aqui então é inevitável a nota de pessimismo quanto aos direitos humanos: a maior parte do que está previsto no PNDH-3 deve se deparar com a negativa, com as mais variadas dificultações, com a impossibilidade de efetivação, o que é péssimo para os anseios concretos imediatos do povo, mas pode ser proveitoso para sua consciência política e para a transformação social. É a esperança que os direitos humanos alimentam.

\footnotetext{
${ }^{186}$ István Mészáros, ob. cit., p. 168.

${ }^{187}$ Luciano Vasapollo, Por uma política de classe: uma interpretação marxista do mundo globalizado. Trad. Juliana Coli. SP: Expressão Popular, 2007, p. 37
} 


\section{BIBLIOGRAFIA}

\section{Obras de Karl Marx (e Friedrich Engels)}

MARX, Karl. Textos escolhidos [col. Os Pensadores]. Ed. José Arthur Gianotti. Trad. José Carlos Bruni e outros. 2. ed. SP: Abril Cultural, 1978.

. O Capital: crítica da economia política [5 vols. - col. Os Economistas]. Trad. Regis Barbosa e Flavio R. Kothe. 2. ${ }^{a}$ ed. SP: Nova Cultural, 1985.

Grundrisse: foundations of the critique of political economy (rough draft).

Trad. Martin Nicolaus. Londres: Penguin Books, New Left Review, 1993.

. O 18 Brumário e Cartas a Kugelmann. Trad. Leandro Konder e Renato Guimarães. 7. ${ }^{\text {e ed. SP: Paz e Terra, } 2002 .}$

Contribuição à crítica da economia política. Trad. Maria Helena Barreiro Alves. 3. a ed. SP: Martins Fontes, 2003.

. Manuscritos econômico-filosóficos. Trad. Jesus Ranieri. SP: Boitempo, 2004.

. O Capital: crítica da economia política [6 vols.]. Trad. Reginaldo Sant'Anna.

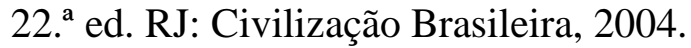

. Crítica da filosofia do direito de Hegel. Trad. Rubens Enderle e Leonardo de

Deus. SP: Boitempo, 2005.

Trabalho assalariado e capital \& Salário, preço e lucro. SP: Expressão Popular, 2006.

. Sobre o suicídio. Trad. Rubens Enderle e F. Fontanella. SP: Boitempo, 2006.

Contribuição à crítica da economia política. Trad. e introd. Florestan

Fernandes. 2. ${ }^{\mathrm{a}}$ ed. SP: Expressão Popular, 2007.

. Miséria da Filosofia: resposta à Filosofia da Miséria, do sr. Proudhon. Trad. José Paulo Netto. SP: Expressão Popular, 2009.

. Para a questão judaica. Trad. Barata-Moura. SP: Expressão Popular, 2009.

. Para a crítica da economia política: manuscrito de 1861-1863 (Cadernos I a V, 3. ${ }^{\circ}$ capítulo: O capital em geral). Trad. Leonardo de Deus. BH: Autêntica, 2010.

. "O método da economia", trad. Fausto Castilho, in Crítica Marxista, n. ${ }^{\text {o } 30, ~ p . ~}$ 103-125, 2010.

2010.

Das Kapital: Kritik der polistichen Ökonomie. 3 v. 33. ed. Berlin: Dietz,

Capítulo VI inédito de O Capital: resultados do processo de produção imediata. SP: Moraes, s/d.

; ENGELS, Friedrich. Textos [3 vols.]. SP: Edições Sociais, 1977. 


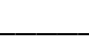
outros. Lisboa, Moscou: Avante, Progresso, 1985.

. Obras escolhidas [em três tomos]. Trad. José Barata-Moura e . História. Org. Florestan Fernandes. 3. a ed. SP: Ática, 1989. ; Manifesto Comunista. Edição crítica em homenagem aos 150 anos, com organização e introdução de Osvaldo Coggiola. SP: Boitempo, 1998. . A Sagrada Família: ou a crítica da Crítica crítica contra Bruno Bauer e consortes. Trad. e notas Marcelo Backes. SP: Boitempo, 2003.

Marcelo Backes. RJ: Civilização Brasileira, 2007. . A ideologia alemã. Organização, tradução, prefácio e notas de - A ideologia alemã. Trad. Rubens Enderle, Nélio Schneider e Luciano Cavini Martorano. SP: Boitempo, 2007.

Boitempo, 2010. . Lutas de classes na Alemanha. Trad. Nélio Schneider. SP:

\section{Estudos sobre Marx}

ALTHUSSER, Louis. Sobre a reprodução. Trad. Guilherme João de Freitas Teixeira. Petrópolis: Vozes, 1999.

. Aparelhos ideológicos de Estado. Trad. Walter José Evangelista e Maria Laura Viveiros de Castro. 9. a ed. RJ: Graal, 2003.

; BALIBAR, Étienne. Para leer El Capital. Trad. Marta Harnecker. 4. ${ }^{\text {a }}$ ed. México: Siglo XXI, 1970.

BALILAR, Étienne. A filosofia de Marx. Trad. Lucy Guimarães. RJ: Zahar, 1995.

BEDESCHI, Giuseppe. Marx. Trad. João Gama. Lisboa: Ed. 70, 1979.

BENSAÏD, Daniel. Marx, o intempestivo: grandezas e misérias de uma aventura crítica (séculos XIX e XX). Luiz Cavalcanti de M. Guerra. RJ: Civilização Brasileira, 1999.

BOITO JR., Armando; TOLEDO, Caio Navarro de; RANIERI, Jesus; TRÓPIA, Patrícia Vieira (orgs.). A obra teórica de Marx: atualidade, problemas e interpretações. 2. ${ }^{a}$ ed. São Paulo: Xamã, 2002.

BORON, Atilio; AMADEO, Javier; GONZÁLEZ, Sabrina. A teoria marxista hoje: problemas e perspectivas. Buenos Aires, SP: CLACSO, Expressão Popular, 2007.

BOTTOMORE, Tom (edit.). Dicionário do pensamento marxista. Trad. Waltensir Dutra. RJ: Jorge Zahar, 2001.

BUEY, Francisco Fernández. Marx (sem ismos). Trad. Luiz Sérgio Henriques. RJ: Ed. UFRJ, 2004.

FAUSTO, Ruy. Marx: Lógica \& Política. Tomo I. SP: Brasiliense, 1983.

. Marx: Lógica \& Política. Tomo II. SP: Brasiliense, 1987.

. Marx: Lógica \& Política. Tomo III. SP: Ed. 34, 2002. 
FREDERICO, Celso. O jovem Marx - 1843-1844: as origens da ontologia do ser social. 2. ${ }^{a}$ ed. SP: Expressão Popular, 2009.

GRESPAN, Jorge Luis da Silva. O negativo do capital: o conceito de crise na crítica de Marx à economia política. SP: Hucitec, 1996.

. Marx. SP: PubliFolha, 2008.

HARVEY, David. A companion to Marx's Capital. London/New York: Verso, 2010.

HOBSBAWM, Eric J. História do Marxismo - vol. 1 (O marxismo no tempo de Marx). RJ: Paz e Terra, 1979.

KOFLER, Leo. História e Dialética: estudos sobre a metodologia da dialética marxista. Trad., José Paulo Netto. RJ: EdUFRJ, 2010.

KONDER, Leandro. A questão da ideologia. SP: Cia. das Letras, 2002.

- A derrota da dialética: a recepção das ideias de Marx no Brasil, até o começo dos anos 30. 2. ${ }^{\text {e }}$ ed. SP: Expressão Popular, 2009.

Marxismo e alienação: contribuição para um estudo do conceito marxista de alienação. 2. ${ }^{a}$ ed. SP: Expressão Popular, 2009.

O marxismo na batalha das ideias. 2. ${ }^{a}$ ed. SP: Expressão Popular, 2009.

KORSCH, Karl. Marxismo e filosofia. Apres. e trad. José Paulo Netto. RJ: Ed. UFRJ, 2009.

KOSIK, Karel. Dialética do concreto. Trad. C. Neves e A. Toríbio. SP: Paz e Terra, 1995.

LÖWY, Michael. As aventuras de Karl Marx contra o Barão de Münchhausen: marxismo e positivismo na sociologia do conhecimento. Trad. Juarez Guimarães, Suzanne Felicie Léwy. SP: Busca Vida, 1987.

. Ideologias e Ciência Social: elementos para uma análise marxista. 4. ${ }^{\mathrm{a}}$ ed. SP: Cortez, 1988.

. A teoria da revolução no jovem Marx. Trad. Anderson Gonçalves. Petrópolis: Vozes, 2002.

; BENSAÏD, Daniel. Marxismo Modernidade Utopia. Org. e apres. José Correa Leite. Trad. Alessandra Ceregatti, Elisabete Burigo, João Machado. SP: Xamã, 2000.

LUKÁCS, Georg. História e consciência de classe: estudos sobre a dialética marxista. Trad. Rodnei Nascimento. SP: Martins Fontes, 2003.

O jovem Marx e outros escritos de filosofia. Org., apres. e trad. Carlos Nelson Coutinho e José Paulo Netto. RJ: Ed. UFRJ, 2007.

LUXEMBURGO, Rosa. Reforma ou revolução? Trad. Livio Xavier. SP: Expressão Popular, 1999.

LESSA, Sérgio; TONET, Ivo. Introdução à filosofia de Marx. SP: Expressão Popular, 2008.

MÉSZÁROS, István. Para além do capital: rumo a uma teoria da transição. Trad. Paulo Cezar Castanheira e Sérgio Lessa. SP: Unicamp, Boitempo, 2002. 
. O século XXI: socialismo ou barbárie? Trad. Paulo Cezar Castanheira. SP: Boitempo, 2003.

. O poder da ideologia. Trad. Paulo Cezar Castanheira. SP: Boitempo, 2004.

. A teoria da alienação em Marx. Trad. Isa Tavares. SP: Boitempo, 2006.

. O desafio e o fardo do tempo histórico: o socialismo no século XXI. Trad. Ana Cotrim, Vera Cotrim. SP: Boitempo, 2007.

. Filosofia, ideologia e ciência social: ensaios de negação e afirmação. Trad.

Ester Vaisman. SP: Boitempo, 2008.

. A crise estrutural do capital. Trad. F. Raul Cornejo. SP: Boitempo, 2009.

. Estrutura social e formas de consciência: a determinação social do método.

Trad. Luciana Pudenzi, Francisco Cornejo e Paulo Castanheira. SP: Boitempo, 2009.

. Atualidade histórica da ofensiva socialista: uma alternativa radical ao sistema parlamentar. Trad. Paulo Cezar Castanheira. SP: Boitempo, 2010.

NAVES, Marcio Bilharinho. Marx: ciência e revolução. SP: Moderna, Unicamp, 2000.

NÓVOA, Jorge (org.). Incontornável Marx. Salvador, SP: Ed. UFBA, Ed. UNESP, 2007.

PAULA, João Antonio de (org.). O ensaio geral: Marx e a crítica da economia política (1857-1858). Belo Horizonte: Autêntica, 2010.

PAULANI, Leda. "A (anti)filosofia de Karl Marx", in SANTOS, Mario Vitor (org.). Os pensadores, um curso. RJ, SP: Casa da Palavra, Casa do Saber, 2009.

POGREBINSCHI, Thamy. O enigma do político: Marx contra a política moderna. RJ: Civilização Brasileira, 2009.

RANIERI, Jesus. A câmara escura: alienação e estranhamento em Marx. SP: Boitempo, 2001.

RENAULT, Emmanuel. Vocabulário de Karl Marx. Trad. Claudia Berliner. SP: Martins Fontes, 2010.

ROSDOLSKI, Roman. Gênese e estrutura de O Capital de Karl Marx. Trad. César Benjamin. RJ: Eduerj, Contraponto, 2001.

SAMPAIO, Benedicto Arthur; FREDERICO, Celso. Dialética e materialismo: Marx entre Hegel e Feuerbach. RJ: Ed. UFRJ, 2006.

TEXIER, Jacques. Revolução e democracia em Marx e Engels. Trad. Duarte Pacheco Pereira. RJ: Ed. UFRJ, 2005.

\section{Sobre o mundo do trabalho}

ANTUNES, Ricardo. A rebeldia do trabalho: o confronto operário no ABC paulista: as greves de 1978/80. SP: Ed. UNICAMP, Ensaio, 1988. 
. Classe operária, sindicatos e partido no Brasil: um estudo sobre a consciência de classe da Revolução de 30 até a Aliança Nacional Libertadora. 3. ${ }^{a}$ ed. SP: Cortez, Ensaio, 1990.

. Os sentidos do trabalho: ensaio sobre a afirmação e a negação do trabalho. SP: Boitempo, 1999.

A desertificação neoliberal no Brasil (Collor, FHC, Lula). Campinas: Autores Associados, 2004.

. O caracol e sua concha: ensaios sobre a nova morfologia do trabalho. SP: Boitempo, 2005.

. Adeus ao Trabalho?: ensaio sobre as metamorfoses e a centralidade do mundo do trabalho. 11. ${ }^{\text {a }}$ ed. SP: Cortez, 2006.

(org.). Neoliberalismo, trabalho e sindicatos: reestruturação produtiva no Brasil e na Inglaterra. SP: Boitempo, 1997.

(org.). Riqueza e miséria do trabalho no Brasil. SP: Boitempo, 2006.

; SILVA, Maria A. Moraes (orgs.). O avesso do trabalho. SP: Expressão Popular, 2004.

; BRAGA, Ruy (orgs.). Infoproletários: degradação real do trabalho virtual. SP: Boitempo, 2009.

ARAÚJO, Ângela (org.). Do corporativismo ao neoliberalismo: Estado e trabalhadores no Brasil e na Inglaterra. SP: Boitempo, 2002.

BEAUD, Stéphane; PIALOUX, Michel. Retorno à condição operária: investigação em fábricas da Peugeot na França. Trad. Mariana Echalar. SP: Boitempo, 2009.

BERNARDO, Marcia Hespanhol. Trabalho duro, discurso flexível: uma análise das contradições do toyotismo a partir da vivência de trabalhadores. SP: Expressão Popular, 2009.

BIHR, Alain. Da grande noite à alternativa: o movimento operário europeu em crise. SP: Boitempo, 1998.

BOITO JR., Armando. Política neoliberal e sindicalismo no Brasil. SP: Xamã, 1999.

BRANDÃO, Nágela Aparecida. Crise e reestruturação capitalista: manutenção ou construção de uma nova ideologia?: uma análise da Central Única dos Trabalhadores. Dissertação de Mestrado em Sociologia, Universidade Estadual de Campinas, 2003.

BRAVERMAN, Harry. Trabalho e capital monopolista: a degradação do trabalho no século XX. Trad. Nathanael C. Caixeiro. 3. ${ }^{\text {a }}$ ed. RJ: LTC, 1987.

CAMILO, Denise Corassa. Comissões de Conciliação Prévia: agilizar ou desregulamentar? Dissertação de Mestrado em Economia, Universidade Estadual de Campinas, 2008.

CARDOSO, Adalberto Moreira. A década neoliberal e a crise dos sindicatos no Brasil. SP: Boitempo, 2003. 
DEJOURS, Christophe. A loucura do trabalho: estudo de psicopatologia do trabalho. Trad. Ana Isabel Paraguay e Lúcia Leal Ferreira. SP: Oboré, 1987.

A banalização da injustiça social. Trad. Luiz Alberto Monjardim. 7. ${ }^{\mathrm{a}}$ ed. RJ: Editora FGV, 2006.

ENGELS, Friedrich. A situação da classe trabalhadora na Inglaterra: segundo as observações do autor e fontes autênticas. Trad. B. A Schumann. SP: Boitempo, 2008.

GALVÃO, Andréia. Neoliberalismo e reforma trabalhista no Brasil. RJ: Revan, FAPESP, 2007.

HOBSBAWM, Eric J. Mundos do trabalho: novos estudos sobre história operária. Trad. Waldea Barcellos e Sandra Bedran. 5. ${ }^{\text {a }}$ ed. revista. SP: Paz e Terra, 2008.

LINHART, Danièle. A desmedida do capital. Trad. Wanda Caldeira Brant. SP: Boitempo, 2007.

LOURENÇO, Edvânia; NAVARRO, Vera; BERTANI, Iris; SILVA, José F. S.; SANT'ANA, Raquel (orgs.). O avesso do trabalho II: trabalho, precarização e saúde do trabalhador. SP: Boitempo, 2010.

LÚCIO, Clemente Ganz; COSTA, Patrícia Lino. "Mercado de trabalho brasileiro: em busca da proteção social", in Direitos Humanos no Brasil 2010. Relatório da Rede Social de Justiça e Direitos Humanos. São Paulo, 2010, pp. 119/129.

MATOS, Marcelo Badaró. Trabalhadores e sindicatos no Brasil. SP: Expressão Popular, 2009.

ORGANISTA, José Henrique Carvalho. O debate sobre a centralidade do trabalho. SP: Expressão Popular, 2006.

PARANHOS, Adalberto. O roubo da fala: origens da ideologia do trabalhismo no Brasil. 2. ${ }^{\text {a }}$ ed. SP: Boitempo, 2007.

PINTO, Geraldo Augusto. A organização do trabalho no século 20: taylorismo, fordismo e toyotismo. SP: Expressão Popular, 2007.

POCHMANN, Marcio. O emprego na globalização: a nova divisão internacional do trabalho e os caminhos que o Brasil escolheu. SP: Boitempo, 2001. . O emprego no desenvolvimento da nação. SP: Boitempo, 2008.

PRIEB, Sérgio Alfredo Massen. A redução do trabalho vivo e a tese do fim da centralidade do trabalho em Schaff e Gorz: uma crítica marxista. Tese de Doutorado em Ciências Econômicas, Universidade Estadual de Campinas, 2002.

ROSSI, Waldemar; GERAB, William Jorge. Para entender os sindicatos no Brasil: uma visão classista. SP: Expressão Popular, 2009.

ROSSO, Sadi Dal. Mais trabalho!: a intensificação do labor na sociedade contemporânea. SP: Boitempo, 2008.

SAES, Décio Azevedo Marques. "Direitos sociais e transição para o capitalismo: o caso da primeira república brasileira (1889-1930)", in Estudos de Sociologia, Araraquara, v. 11, n. 20, 2006. 
SILVER, Beverly J. Forças do trabalho: movimentos de trabalhadores e globalização desde 1870. Trad. Fabrizio Rigout. SP: Boitempo, 2005.

TRÓPIA, Patrícia Vieira. Força sindical: política e ideologia no sindicalismo brasileiro. SP: Expressão Popular, 2009.

VASAPOLLO, Luciano. Trabalho atípico e precariedade. SP: Expressão Popular, 2005. Por uma política de classe: uma interpretação marxista do mundo globalizado. Trad. Juliana Coli. SP: Expressão Popular, 2007.

\section{Filosofia, teoria e demais obras jurídicas}

ABRAMOVICH, Victor; COURTIS, Christian. Los derechos sociales como derechos exigibles. Madrid: Trotta, 2002.

ALEXY, Robert. Teoria dos direitos fundamentais. Trad. Virgílio Afonso da Silva. SP: Malheiros, 2008.

ALMEIDA, Silvio Luiz de. O direito no jovem Lukács: a filosofia do direito em História e Consciência de Classe. SP: Alfa-Ômega, 2006.

ALVES, Alaôr Caffé. Estado e ideologia: aparência e realidade. SP: Brasiliense, 1987. . Lógica: pensamento formal e argumentação. SP: Edipro, 2000. . "As raízes sociais da filosofia do direito - uma visão crítica", in BITTAR, Eduardo (org.). O que é a filosofia do Direito? SP: Manole, 2004.

. "A normatividade e a estrutura social como dimensões históricas", in BITTAR, Eduardo (org.). Direito, sociedade e economia: leituras marxistas. SP: Manole, 2005.

. "Fundamentos dos direito e meio ambiente", in PHILIPPI JR., Arlindo; (orgs.). Curso interdisciplinar de direito ambiental. SP: Manole, 2005.

Dialética e Direito - linguagem, sentido e realidade: fundamentos a uma teoria crítica da interpretação do direito. SP: Manole, 2010.

ATIENZA, Manuel; MANERO, Juan. Marxismo y filosofía del derecho. México: Fontamara, 1998.

AZEVEDO, Plauto Faraco de. Direito, justiça social e neoliberalismo. SP: RT, 1999.

BARROSO, Luís Roberto. O direito constitucional e a efetividade de suas normas: limites e possibilidades da Constituição Brasileira. 8. ${ }^{a}$ ed. RJ: Renovar, 2006.

Curso de Direito Constitucional Contemporâneo: os conceitos fundamentais e a construção do novo modelo. SP: Saraiva, 2009.

BERCOVICI, Gilberto. "A problemática da constituição dirigente: algumas considerações sobre o caso brasileiro", in Revista de Informação Legislativa, Brasília, n. 142, p. 35/51, abr/jun 1999.

. Constituição e estado de exceção permanente. RJ: Azougue, 2004. 
. "Dilemas da concretização da Constituição de 1988", in Revista do Instituto de Hermenêutica Jurídica, Porto Alegre, v. 1, n. 2, p. 101-120, 2004.

- Constituição econômica e desenvolvimento: uma leitura a partir da Constituição de 1988. SP: Malheiros, 2005.

Soberania e Constituição: para uma crítica do constitucionalismo. SP: Quartier Latin, 2008.

, MASSONETTO, Luís Fernando, "A Constituição Dirigente Invertida: a blindagem da constituição financeira e a agonia da constituição econômica", in COUTINHO, Jacinto Nelson de Miranda; MORAIS, José Luis Bolzan de; STRECK, Lenio Luiz (orgs.). Estudos constitucionais. RJ: Renovar, 2007, pp. 121-136.

BITTAR, Eduardo C. B. "E quando o Estado desaparece numa ordem capitalista?", in $\overline{2005}$. (org.). Direito, sociedade e economia: leituras marxistas. SP: Manole,

. "Filosofia crítica e filosofia do direito: por uma filosofia social do direito", in revista Cult, v. 112, pp. 53-55, São Paulo, 2007.

. O direito na pós-modernidade (e reflexões frankfurtianas). 2. ${ }^{a}$ ed. rev., atual. e ampl. RJ: Forense Universitária, 2009.

(org.). História do direito brasileiro. SP: Atlas, 2003.

BONAVIDES, Paulo. Curso de direito constitucional. 14. ${ }^{\mathrm{a}}$ ed. SP: Malheiros, 2004.

. Do país constitucional ao país neocolonial: a derrubada da Constituição e a recolonização pelo golpe de Estado institucional. 3. ${ }^{\mathrm{a}}$ ed. SP: Malheiros, 2004.

. Do estado liberal ao estado social. 7. a ed., 2. ${ }^{\text {a }}$ tir. SP: Malheiros, 2004.

CANOTILHO, J. J. Gomes. Constituição dirigente e vinculação do legislador: contributo para a compreensão das normas programáticas constitucionais. 2. ${ }^{\mathrm{a}}$ ed. Coimbra: Coimbra, 2001. 2002.

CERRONI, Umberto. Pensamento jurídico soviético. Trad. Maria de Lurdes Sá Nogueira. Mem Martins: Europa-América, 1976.

COELHO, Luiz Fernando. Introdução à critica do direito. Curitiba: HDV, 1983.

. Teoria crítica do direito. 3. ${ }^{\mathrm{a}}$ ed. Belo Horizonte: Del Rey, 2003.

COMPARATO, Fábio Konder. Muda Brasil: uma Constituição para o desenvolvimento democrático. SP: Brasiliense, 1986.

. Para viver a democracia. SP: Brasiliense, 1989.

CORREIA, Marcus Orione Gonçalves (org.). Curso de Direito do Trabalho - vol. I (Teoria Geral do Direito do Trabalho). SP: LTr, 2007.

CORREAS, Óscar. Crítica da ideologia jurídica: ensaio sócio-semiológico. Trad. Roberto Bueno. Porto Alegre: SAFe, 1995.

. Sociología del derecho e crítica jurídica. México: Fontamara, 1998. 
COSTA, José Ricardo Caetano. Previdência e Neoliberalismo. Porto Alegre: Livraria do Advogado, 2001.

COUTINHO, Grijalbo Fernandes; MELO FILHO, Hugo Cavalcanti; SOUTO MAIOR, Jorge Luiz; FAVA, Marcos Neves (coords.). O mundo do trabalho: leituras críticas da jurisprudência do TST: em defesa do direito do trabalho. Vol. I. SP: LTr, 2009.

COUTINHO, Jacinto N. de M., LIMA, Martonio M. B. (orgs.). Diálogos constitucionais: direito, neoliberalismo e desenvolvimento em países periféricos. RJ: Renovar, 2006.

DAVID, René. Os Grandes Sistemas do Direito Contemporâneo. Trad. Hermínio A. Carvalho. 3. ${ }^{a}$ ed., 2. ${ }^{a}$ tir. SP: Martins Fontes, 1998.

EMERIQUE, Lilian Balmante. Neoconstitucionalismo e direitos sociais: um contributo para a luta contra a pobreza. RJ: FAPERJ, Freitas Bastos, 2009.

FERNANDES, Pádua. Para que servem os direitos humanos? Coimbra: Angelus Novus, 2009.

FON FILHO, Aton. "Dimensão política dos direitos humanos", in Direitos Humanos no Brasil 2010. Relatório da Rede Social de Justiça e Direitos Humanos. São Paulo, 2010, pp. 103/108. Disponível também em <http://www.social.org.br/>

GEBRIM, Ricardo; BARISON, Thiago. "As novas formas de repressão a greves", in Direitos Humanos no Brasil 2010. Relatório da Rede Social de Justiça e Direitos Humanos. São Paulo, 2010, pp. 131/136.

GRAU, Eros R. A ordem econômica na constituição de 1988. 8. a ed. SP: Malheiros, 2003.

Ensaio e discurso sobre interpretação/aplicação do direito. 2. ${ }^{a}$ ed. SP: Malheiros, 2003.

; GUERRA FILHO, Willis Santiago (orgs.). Direito constitucional: estudos em homenagem a Paulo Bonavides. SP: Malheiros, 2001.

; CUNHA, Sérgio Sérvulo da (coords.). Estudos de direito constitucional: em homenagem a José Afonso da Silva. SP: Malheiros, 2003.

HESPANHA, António Manuel. Panorama histórico da cultura jurídica européia. 2. ${ }^{a}$ ed. Mem Martins: Europa-América, 1998.

HESSE, Konrad. A força normativa da constituição. Trad. Gilmar Ferreira Mendes. Porto Alegre: SAFe, 1991.

KASHIURA JÚNIOR, Celso Naoto. Crítica da Igualdade Jurídica: contribuição ao pensamento jurídico marxista. SP: Quartier Latin, 2009.

KAUFMANN, Arthur; HASSEMER, Winfried (orgs.). Introdução à filosofia do direito e à teoria do direito contemporâneas. Trad. Marcos Keel e Manuel Seca de Oliveira. Rev. cient. António Manuel Hespanha. Lisboa: Calouste Gulbenkian, 2002.

LIMA, Martonio Mont'Alverne Barreto, ALBUQUERQUE, Paulo Antonio de Menezes (orgs.). Democracia, direito e política: estudos internacionais em homenagem a Friedrich Müller. Florianópolis: Conceito Editorial, 2006.

; BELLO, Enzo (coords.). Direito e Marxismo. RJ: Lumen Juris, 2010. 
LYRA FILHO, Roberto. Karl, meu amigo: diálogo com Marx sobre o direito. Porto Alegre: SAFe, Instituto dos Advogados do RS, 1983.

MACHADO, Antônio Alberto. Ensino jurídico e mudança social. 2. ${ }^{a}$ ed. SP: Expressão Popular, 2009.

MARÍ, Enrique E., RUIZ, Alicia E. C. et allii. Materiales para una teoría crítica del derecho. Buenos Aires: Abeledo-Perrot, 1991.

MASCARO, Alysson Leandro. Crítica da legalidade e do direito brasileiro. SP: Quartier Latin, 2003.

Filosofia do Direito. SP: Atlas, 2010.

MELO, Tarso de. Direito e Ideologia: um estudo a partir da função social da propriedade rural. SP: Expressão Popular, 2009.

"Neoliberalismo e 'reserva do possível"', in Revista da Faculdade de Direito de São Bernardo do Campo, ano 13, n. 15, S. Bernardo Campo, 2009, pp. 167-176.

MIAILLE, Michel. Introdução crítica ao direito. Trad. Ana Prata. 2. ${ }^{a}$ ed. Lisboa: Estampa, 1989 [col. Imprensa Universitária n. ${ }^{\circ}$ 70].

MONREAL, Eduardo Novoa. O direito como obstáculo à transformação social. Trad. Gérson Pereira dos Santos. Porto Alegre: SAFe, 1988.

MOREIRA, Vital. A ordem jurídica do capitalismo. Lisboa: Caminho, 1987.

MUTUA, Makau wa. "The ideology of human rights", in Virginia Journal of International Law, v. 36, n. 3, Spring 1996, pp. 589-657.

NAVES, Marcio B. Marxismo e direito: um estudo sobre Pachukanis. SP: Boitempo, 2000.

(org.). O discreto charme do direito burguês: ensaios sobre Pachukanis. Campinas: IFHC/UNICAMP, 2009.

NEVES, Marcelo. A constitucionalização simbólica. SP: Acadêmica, 1994.

NUNES, António José Avelã. “A Constituição Européia: a constitucionalização do neoliberalismo", in COUTINHO, Jacinto Nelson de Miranda; LIMA, Martonio Mont'Alverne Barreto (orgs.), Diálogos Constitucionais: direito, neoliberalismo e desenvolvimento em países periféricos. Rio de Janeiro: Renovar, 2007, pp. 63/118.

OLIVEIRA NETO, Francisco José Rodrigues de; COUTINHO, Jacinto Nelson de Miranda; MEZZAROBA, Orides; BRANDÃO, Paulo de Tarso (orgs.). Constituição $e$ Estado Social: os obstáculos à concretização da Constituição. Coimbra: Ed. Coimbra, SP: RT, 2008.

PASUKANIS, Eugeny Bronislanovich. A teoria geral do direito e o marxismo. Trad. Paulo Bessa. RJ: Renovar, 1989.

PLASTINO, Carlos Alberto (org.). Crítica do direito e do estado. RJ: Graal, 1984.

SAMPAIO, José Adércio Leite (coord.). 15 anos de constituição: história e vicissitudes. Belo Horizonte: Del Rey, 2004.

SARLET, Ingo Wolfgang. "Os direitos fundamentais sociais na Constituição de 1988”, in $O$ direito público em tempos de crise: estudos em homenagem a Ruy Ruben Ruschel. Porto Alegre: Livraria do Advogado, 1999. 
SARLET, Ingo Wolfgang. A eficácia dos direitos fundamentais. 6. ${ }^{a}$ ed., Porto Alegre: Livraria do Advogado, 2006.

SILVA, Alessandro; SOUTO MAIOR, Jorge L.; FELIPPE, Kenarik B.; SEMER, Marcelo (coords.). Direitos humanos - essência do direito do trabalho. SP: LTr, 2007.

SILVA, José Afonso da. Curso de direito constitucional positivo. 16. ${ }^{\mathrm{a}}$ ed. SP: Malheiros, 1999.

. Aplicabilidade das normas constitucionais. 6. ${ }^{\mathrm{a}}$ ed. SP: Malheiros, 2002.

Comentário contextual à Constituição. SP: Malheiros, 2005.

SOUTO MAIOR, Jorge Luiz. O direito do trabalho como instrumento de justiça social. SP: LTr, 2000.

Relação de emprego \& Direito do Trabalho - no contexto da ampliação da competência da Justiça do Trabalho. SP: LTr, 2007.

Curso de Direito do Trabalho - vol. II (A relação de emprego). SP: Ltr, 2008.

STRECK, Lenio Luiz. Hermenêutica jurídica e $(m)$ crise: uma exploração hermenêutica da construção do direito. 4. ${ }^{a}$ ed. Porto Alegre: Livraria do Advogado, 1999.

. Jurisdição constitucional e hermenêutica: uma nova crítica do direito. $2 .^{\mathrm{a}}$ ed.

RJ: Forense, 2004.

TIGAR, Michael E.; LEVY, Madeleine R. O direito e a ascensão do capitalismo. Trad. Ruy Jungmann. RJ: Zahar, 1978.

TUMÁNOV, Vladimir. O pensamento jurídico burguês contemporâneo. Trad. Palmeiro Gonçalves. Lisboa: Caminho, 1985.

VV. AA. Filosofia do direito e direito econômico: que diálogo?: miscelâneas em honra de Gérard Farjat. Trad. Jorge Pinheiro. Lisboa: Instituto Piaget, s/d.

WOLKMER, Antonio Carlos. Ideologia, estado e direito. 3. a ed. SP: RT, 2000.

Introdução ao pensamento jurídico crítico. 5. a ed. SP: Saraiva, 2006.

\section{Outras obras consultadas}

ABBAGNANO, Nicola. Dicionário de Filosofia. Trad. Alfredo Bosi. 3. ${ }^{a}$ ed., 2. ${ }^{a}$ tir. SP: Martins Fontes, 1999.

ABREU, Haroldo. Para além dos direitos: cidadania e hegemonia no mundo moderno. RJ: Edit. UFRJ, 2008.

ARNAUD, André-Jean. Dicionário enciclopédico de teoria e de sociologia do direito. Trad. Vicente de Paulo Barreto. RJ: Renovar, 1999.

ARRIGUI, Giovanni. $O$ longo século $X X$ : dinheiro, poder e as origens do nosso tempo. Trad. Vera Ribeiro. RJ, SP: Contraponto, Ed. Unesp, 1996.

A ilusão do desenvolvimento. Trad. Sandra Vasconcelos. 2. ${ }^{\text {a }}$ ed. Petrópolis: Vozes, 1997. 
BEER, Max. História do Socialismo e das lutas sociais. Trad. Horácio de Melo. SP: Expressão Popular, 2006.

BELLUZZO, Luiz Gonzaga de Mello. Ensaios sobre o capitalismo no século XX. Sel. e org. F. Mazzucchelli. SP, Campinas: Ed. UNESP, Ed. UNICAMP, 2004.

BERNARDO, João. Economia dos conflitos sociais. SP: Cortez, 1991.

BOBBIO, Norberto; MATEUCCI, Nicola; PASQUINO, Gianfranco. Dicionário de

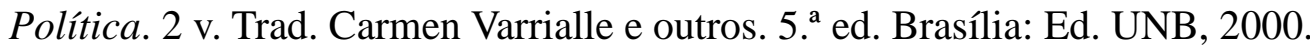

BORON, Atilio A. O socialismo no século 21: há vida após o neoliberalismo? Trad. Fabiane Tejada da Silveira. SP: Expressão Popular, 2010.

BOSI, Alfredo. Ideologia e contraideologia: temas e variações. SP: Cia. das Letras, 2010.

BOTTOMORE, Tom; OUTHWAITE (edits.). Dicionário do pensamento social do século XX. Trad. Eduardo Francisco Alves e Álvaro Cabral. RJ: Jorge Zahar, 1996.

CANFORA, Luciano. A democracia: história de uma ideologia. Trad. José Jacinto Correia Serra. Lisboa: Edições 70, 2007.

. Crítica da retórica democrática. Trad. V. Silva. SP: Estação Liberdade, 2007.

CARVALHO, José Murilo. Cidadania no Brasil. 6. ${ }^{a}$ ed. RJ: Civilização Brasileira, 2004.

CERRONI, Umberto. Teoria política e socialismo. Trad. Fernando Melro. Mem Martins: Europa-América, 1976.

CHAUI, Marilena. O que é ideologia (col. Primeiros Passos). SP: Brasiliense, 1980.

CHESNAIS, François. A mundialização do capital. Trad. Silvana Foá. SP: Xamã, 1996.

(coord.). A mundialização financeira: gênese, custos e riscos. Trad. Carmen Cristina Cacciacarro, Luís Leiria, Silvana Foá e Valéria Coelho da Paz: SP: Xamã, 1998.

(org.). A finança mundializada: raízes sociais e políticas, configuração, consequiências. Trad. Rosa Marques e Paulo Nakatani. SP: Boitempo, 2005.

DOBB, Maurice. Theories of value and distribution since Adam Smith: ideology and economic theory. Cambridge University Press, s/d. , A evolução do capitalismo. Trad. Manuel Rego Braga. 9. a ed. RJ: LTC, 1987.

EAGLETON, Terry. Ideologia: uma introdução. Trad. Luís Carlos Borges e Silvana Vieira. SP: Boitempo, Ed. Unesp, 1997.

ELEY, Geoff. Forjando a democracia: a história da esquerda na Europa 1850-2000. Tard. Paulo Cezar Castanheira. SP: Fundação Perseu Abramo, 2005.

FILGUEIRAS, Luiz. História do Plano Real: fundamentos, impactos e contradições. 3. ${ }^{\mathrm{a}}$ ed. SP: Boitempo, 2006.

FIORI, José Luís. Os moedeiros falsos. 4. a ed. Petrópolis: Vozes, 1998.

O poder global: e a nova geopolítica das nações. SP: Boitempo, 2007.

HARVEY, David. O novo imperialismo. Trad. Adail Sobral e Maria Stela Gonçalves. SP: Loyola, 2004. 
. Condição pós-moderna: uma pesquisa sobre as origens da mudança cultural.

Trad. Adail Ubirajara Sobral e Maria Stela Gonçalves. 14. ${ }^{a}$ ed. SP: Loyola, 2005.

. A brief history of neoliberalism. New York: Oxford, 2005.

2006.

O neoliberalismo: história e implicações. Trad. Adail Sobral e Maria Stela Gonçalves. SP: Loyola, 2008.

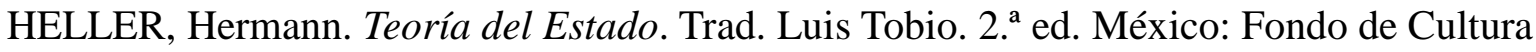
Económica, 1998.

HIRSCH, Joachim. Teoria materialista do Estado. Trad. Luciano Cavini Martorano. RJ: Revan, 2010.

IASI, Mauro Luis. $O$ dilema de Hamlet: o ser e o não ser da consciência. SP: Viramundo, 2002.

As metamorfoses da consciência de classe: o PT entre a negação e o consentimento. SP: Expressão Popular, 2006.

. Ensaios sobre consciência e emancipação. SP: Expressão Popular, 2007.

. "A crise do capital: a era da hipocrisia deliberada", in Revista PraiaVermelha, Rio de Janeiro, v. 19, n. ${ }^{\circ}$ 1, p. 25-40, jan-jun. 2009.

LESBAUPIN, Ivo (org.). O desmonte da nação: balanço do governo FHC. 4. ${ }^{\mathrm{a}}$ ed. Petrópolis: Vozes, 2003.

; MINEIRO, Adhemar. O desmonte da nação em dados. Petrópolis: Vozes, 2002.

LOSURDO, Domenico. Hegel, Marx e a tradição liberal: liberdade, igualdade, Estado. Trad. Carlos Alberto Fernando Nicola Dastoli. SP: Ed. Unesp, 1998.

Democracia ou bonapartismo: triunfo e decadência do sufrágio universal. Trad. Luiz Sérgio Henriques. RJ: Ed. UFRJ, 2004.

Contra-história do liberalismo. Trad. Giovanni Semeraro. Aparecida: Idéias \& Letras, 2006.

LUKÁCS, G. Ontologia do ser social. Os princípios ontológicos fundamentais de Marx. Trad. Carlos Nelson Coutinho. SP: Ciências Humanas, 1979.

. Ontologia do ser social. A falsa e a verdadeira ontologia de Hegel. Trad. Carlos Nelson Coutinho. SP: Ciências Humanas, 1979.

. Per l'ontologia dell'essere sociale. 2 vols. Trad. Alberto Scarponi. Roma: Riuniti, 1976-1981.

. Socialismo e democratização: escrito políticos 1956-1971. Org., introd. e trad. Carlos Nelson Coutinho e José Paulo Netto. RJ: UFRJ, 2008.

Prolegômenos para uma ontologia do ser social. Trad. Lya Luft e Rodnei Nascimento. SP: Boitempo, 2010. 
MARCUSE, Herbert. Ideologia da sociedade industrial. Trad. Giasone Rebuá. 3. a ed. RJ: Zahar, 1969.

. Idéias sobre uma teoria crítica da sociedade. Trad. Fausto Guimarães. RJ: Zahar, 1972.

MARRAMAO, Giacomo. O político e as transformações: crítica do capitalismo e ideologias da crise entre os anos vinte e trinta. Trad. Antonio Roberto Bertelli. Belo Horizonte: Oficina de Livros, 1990.

OLIVEIRA, Francisco de. Os direitos do antivalor: a economia política da hegemonia imperfeita. Petrópolis: Vozes, 1998.

; PAOLI, Maria Célia (orgs.). Os sentidos da democracia: políticas do dissenso e hegemonia global. 2. ${ }^{\mathrm{a}}$ ed. Petrópolis: Vozes, 2000.

; RIZEK, Cibele S. (orgs.). A era da indeterminação. SP: Boitempo, 2007.

2010. ; BRAGA, Ruy (orgs.). Hegemonia às avessas. SP: Boitempo,

PAULANI, Leda. Modernidade e discurso econômico. SP: Boitempo, 2005.

. Brasil Delivery: servidão financeira e estado de emergência econômico. SP: Boitempo, 2008.

PAULO NETTO, José. Democracia e transição socialista: escritos de teoria e política. Belo Horizonte: Oficina de Livros, 1990.

PETRAS, James. A armadilha neoliberal e alternativas para a América Latina, SP: Xamã, 1999.

PINASSI, Maria Orlanda. Da miséria ideológica à crise do capital: uma reconciliação histórica. SP: Boitempo, 2009.

ROSENMANN, Marcos Roitman. "Neoliberalismo", in SADER, Emir; JINKINGS, Ivana (coords.), Latinoamericana: enciclopédia contemporânea da América Latina e do Caribe. SP: Boitempo, 2006, pp. 848-855.

SAES, Décio. República do Capital: capitalismo e processo político no Brasil. SP: Boitempo, 2001.

SAMPAIO, Plínio de Arruda. "Fruto de uma ilusão", in revista Versus (Revista de Ciências Sociais Aplicadas do CCJE/UFRJ), dossiê 20 anos de Constituição: o pacto pós-ditadura, dezembro de 2008, pp. 18-19.

THOMPSON, John B. Ideologia e cultura moderna: teoria social crítica na era dos meios de comunicação de massa. 8. ${ }^{a}$ ed. Petrópolis: Vozes, 2009.

VAISMAN, Ester. "A ideologia e sua determinação ontológica”, in Revista Ensaio, n. 17/18, p. 399-444, São Paulo, 1989.

VÁZQUEZ, Adolfo Sánchez. Filosofia da práxis. Trad. Luiz Fernando Cardoso. 3. a ed. RJ: Paz e Terra, 1986.

WOOD, Ellen Meiksins. Democracia contra capitalismo: a renovação do materialismo histórico. Trad. Paulo Cezar Castanheira. SP: Boitempo, 2003. 
. "Capitalism and social rights", in Against The Current, n. ${ }^{\circ}$ 140, May/June 2009 - endereço eletrônico: http://www.solidarity-us.org/current/node/2150.

; FOSTER, John Bellamy (orgs.). Em defesa da história: marxismo e pósmodernismo. Trad. Ruy Jungmann. RJ: Jorge Zahar, 1999.

ZIZEK, Slavoj (org.). Um mapa da ideologia. Trad. Vera Ribeiro. RJ: Contraponto, 1996. 


\section{RESUMO}

O presente trabalho tem por objetivo demonstrar como o direito, ao passo em que exerce função essencial como instrumento de dominação entre classes sociais, apresenta-se também como importante instrumento de resistência política da classe trabalhadora. Tal importância ultrapassa a simples efetividade das normas no campo jurídico e ganha especial relevância na forma como se traduzem juridicamente as lutas de classes, o que faz com que as reivindicações políticas transformadas em direitos, por mais que em grande medida se neutralizem de acordo com os interesses hegemônicos, permaneçam no horizonte político da sociedade, alimentando a tensão por transformação social.

Para tanto, este trabalho percorre um itinerário teórico dividido em três movimentos. Inicialmente, estuda a forma como se constitui e complexifica a noção de ideologia nas obras de Karl Marx, desde as obras iniciais até sua reflexão mais madura. $\mathrm{O}$ segundo movimento é dedicado a localizar o papel exercido pelo direito no conjunto da ideologia social e indaga as possibilidades de uma teoria da ideologia jurídica. Em seu terceiro e último movimento, a fim de demonstrar concretamente a problemática da tese, dedica-se à investigação da relação entre ambiguidade e resistência no caso dos direitos sociais, em especial os direitos dos trabalhadores previstos na Constituição brasileira de 1988, cuja vigência se dá sob forte pressão neoliberal. Neste passo, aproveita-se fartamente do diálogo com a sociologia crítica do trabalho contemporânea, no intuito de verificar como as lutas concretas dos trabalhadores transitam entre o direito, a política e a ideologia.

PALAVRAS-CHAVE: crítica do direito - ideologia - transformação social neoliberalismo - direitos sociais - marxismo - ambiguidade - resistência 


\begin{abstract}
The present work intends to show how law plays not only an essential function as an instrument of domination between social classes, but it is also an important element of working class' political resistance. This importance exceeds the rules established in the juridical field and reaches special relevance in the way that it translates class struggles, what makes political claims turned into rights, in spite of the fact that its large measure could be neutralized according to hegemonic interests, remaining on the society's political surface, feeding the social transformation tension.

This work follows a theoretical line divided in three movements. Firstly, it studies the way that ideological notion in Karl Marx's work is established and complexified, since the beginning of his works until the most mature ideas developed by him. The second movement intends to find the role played by law in the social ideological field questioning the possibilities of a juridical ideology's theory. The third and last movement, is developed with the main intention to show effectively what this thesis is all about, it also proposes an investigation on the relations between ambiguity and resistance in social rights' case, mainly based on workers' rights provided in 1988's Brazilian Constitution under the neoliberal pressure. In this sense the discourse of the contemporary critical sociology of work is widely used, aiming to verify how real working class fights flows through the law, politics and ideology.
\end{abstract}

KEYWORDS: law critical theory - ideology - social transformation - neoliberalism social rights - Marxism - ambiguity - resistance 


\section{RIASSUNTO}

Il presente lavoro intende dimonstrare come il diritto, mentre esercita la funzione essenziale come strumento di dominazione fra le classi sociali, è anche presente come un importante strumento di resistenza politica della classe operaia. Tale importanza va oltre la semplice efficacia delle norme nel campo giuridico e ottiene una particolare attenzione su come le leggi riflettono le lotte di classe, e fa rivendicazione politica trasformata in legge, anche se sono neutralizzati dagli interessi egemonici, rimane l'orizzonte politico della società, promuovendo la tensione per la trasformazione sociale.

Pertanto, il presente lavoro segue un percorso teorico diviso in tre movimenti. Inizialmente, studia la forma come costituice e diventa complessa la nozione di ideologia nelle opere di Karl Marx, dei primi testi a le sue opere della maturità. Il secondo movimento è dedicato alla ricerca del ruolo svolto per diritto in tutta l'ideologia sociale e indaga la possibilità di una teoria della ideologia giuridica. Nel suo terzo e ultimo movimento, per dimostrare concretamente il problema della tesi, indaga il rapporto tra ambiguità e resistenza nel caso dei diritti sociali, in particolare i diritti dei lavoratori dalla Costituzione brasiliana del 1988, oggetto di una forte pressione liberista. Infine, si avvale ampiamente del dialogo con il contemporaneo sociologia critica del lavoro, con l'obiettivo di verificare come le lotte concrete dei lavoratori comporta il diritto, politica e ideologia.

PAROLE: critica del diritto - ideologia - trasformazione sociale - neoliberismo - diritti sociali - marxismo - ambiguità - resistenza 